\title{
A Bronze Age Round Barrow Cemetery, Pit Alignments, Iron Age Burials, Iron Age Copper Working, and Later Activity at Four Crosses, Llandysilio, Powys
}

\section{Tim Havard, Timothy Darvill \& Mary Alexander}

To cite this article: Tim Havard, Timothy Darvill \& Mary Alexander (2016): A Bronze Age Round Barrow Cemetery, Pit Alignments, Iron Age Burials, Iron Age Copper Working, and Later Activity at Four Crosses, Llandysilio, Powys, Archaeological Journal, DOI: 10.1080/00665983.2017.1238687

To link to this article: http://dx.doi.org/10.1080/00665983.2017.1238687

\section{Published online: 14 Oct 2016.}

Submit your article to this journal ए

View related articles $\longleftarrow$

View Crossmark data ¿ 


\title{
A Bronze Age Round Barrow Cemetery, Pit Alignments, Iron Age Burials, Iron Age Copper Working, and Later Activity at Four Crosses, Llandysilio, Powys
}

\author{
T I M H A V A R , TIMOTHY D A R V IL L A N D \\ MAR Y A LEX A N D ER \\ With contributions by Rowena Gale, Harriet Jacklin, Helen Lewis, Ed McSloy, \\ Elizabeth Pearson, Keith Wilkinson and Tim Young
}

Excavation undertaken at the Upper Severn valley round barrow cemetery at Four Crosses, Llandysilio, Powys, between 2004 and 2006 has increased the known barrows and ring ditches to some twenty-seven monuments within this complex, and revealed additional burials. Based on limited dating evidence, and the data from earlier excavations, the majority of the barrows are thought to be constructed in the Bronze Age. The barrows are considered part of a larger linear cemetery. The landscape setting and wider significance of this linear barrow cemetery are explored within this report. Dating suggests two barrows were later, Iron Age additions. The excavation also investigated Iron Age and undated pit alignments, Middle Iron Age copper working and a small Romano-British inhumation cemetery and field systems. Much of this evidence reflects the continuing importance of the site for ritual and funerary activity.

\section{INTRODUCTION}

The important round barrow cemetery at Four Crosses, Llandysilio, Powys, has been known since the I960s and I970s through aerial reconnaissance. Prior to 2002, the site was known to contain at least five ring ditch crop marks, three of which had been excavated by CPAT in the I980s (Illus. 2: Barrow 2, Barrow 3 and Barrow 8) together with a series of pit alignments. The barrows were considered to belong to the Beaker to Early Bronze Age period, although dating was poor (Warrilow et al. I986, 83).

Between 2004 and 2006 an opportunity to investigate elements of this barrow cemetery arose ahead of residential development at Domgay Road, Four Crosses (centred on NGR SJ 2707 I 878) (Illus. I). Geophysical survey and trial trenching in 2002 and 2003 respectively confirmed the presence of a further twelve barrows or ring ditches, alongside pit alignments and elements of a ditched field system (Jones 2002; Marches Archaeology 2003). Dating 


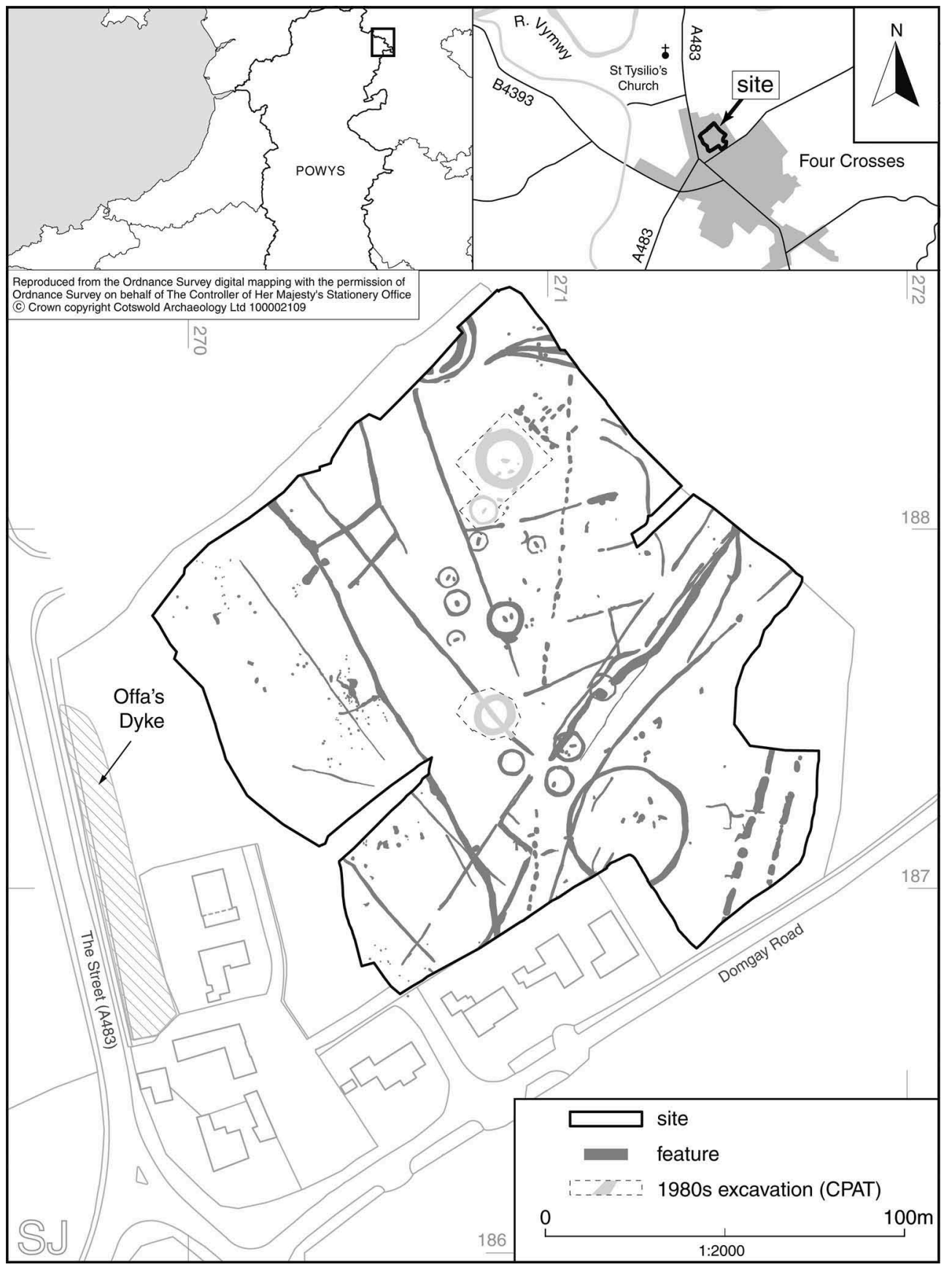

ILLUS. I Site location 
evidence from trial trenching suggested an Iron Age date for one of the pit alignments, and the presence of Roman and post-medieval ditches (Marches Archaeology 2003, 30).

The site was subject to area excavation by Cotswold Archaeology between 2004 and 2006 before construction of the new housing development. Archaeological features exposed by machine stripping were hand-excavated, employing standard sampling strategies. This report sets out the results of these excavations.

\section{THE EXCAVATIONS}

The site comprises an area of approximately 2.4 ha in the north of Four Crosses, and is situated on a low gravel terrace ( $c .60 \mathrm{~m}$ OD) close to the confluence of the rivers Severn and Vyrnwy. The course of Offa's Dyke runs less than Ioo $\mathrm{m}$ to the west. The site was under pasture prior to excavation and was generally flat, although the southern half of a barrow mound (Illus. 2: Barrow 20) lay in the north of the site on top of a slight natural rise. The solid geology of the site is mapped as Early Triassic Kinnerton sandstone formation, sealed by Devensian glacial-fluvial deposits of sands and gravel (BGS).

The principal features of the 2004-6 excavation were eight previously unrecorded ring ditches or barrows of the Four Crosses barrow cemetery. The monuments of the barrow cemetery are described from south to north, rather than by sequence, as not all the monuments could be dated with any certainty. As barrows of this cemetery have previously been allocated unique identifiers (Barrows I-8), that number sequence is continued and now provides for a total of twenty-seven monuments. These are listed in Appendix A, with a summary description of each one. All the ring ditched features on site are referred to as barrows, although evidence for a mound was not always present.

Other activity on the site was represented by a pit containing Grooved Ware pottery, Iron Age pits containing copper working debris, Iron Age pit alignments, and Romano-British enclosures, field systems and a small inhumation cemetery. These features are described in chronological order. In addition to these features, a series of post-medieval and modern field boundaries were recorded and these are not discussed further in this report.

Radiocarbon determinations are presented as calibrated dates though conventional radiocarbon ages (Stuiver and Polach I977) are given in Table I. All calibrations have been calculated using the calibration curve of Reimer et al. (2004), and the computer program OxCal 3.IO Bronk Ramsey (2005). Date ranges cited in the text are those at 95\% confidence level (two sigma) unless otherwise specified. Ranges are derived from the probability method (Stuiver and Reimer I993).

The interpretation of date and function of the features excavated on this site are those of the authors. As with many sites for which a securely dated sequence is lacking, other interpretations are also possible.

\section{SITE LAYOUT}

The barrows, represented by ring ditches of varying sizes, were loosely arranged on a north-south alignment in the centre of the site. The arrangement of other features found within the excavated area would suggest that the barrows remained as significant 


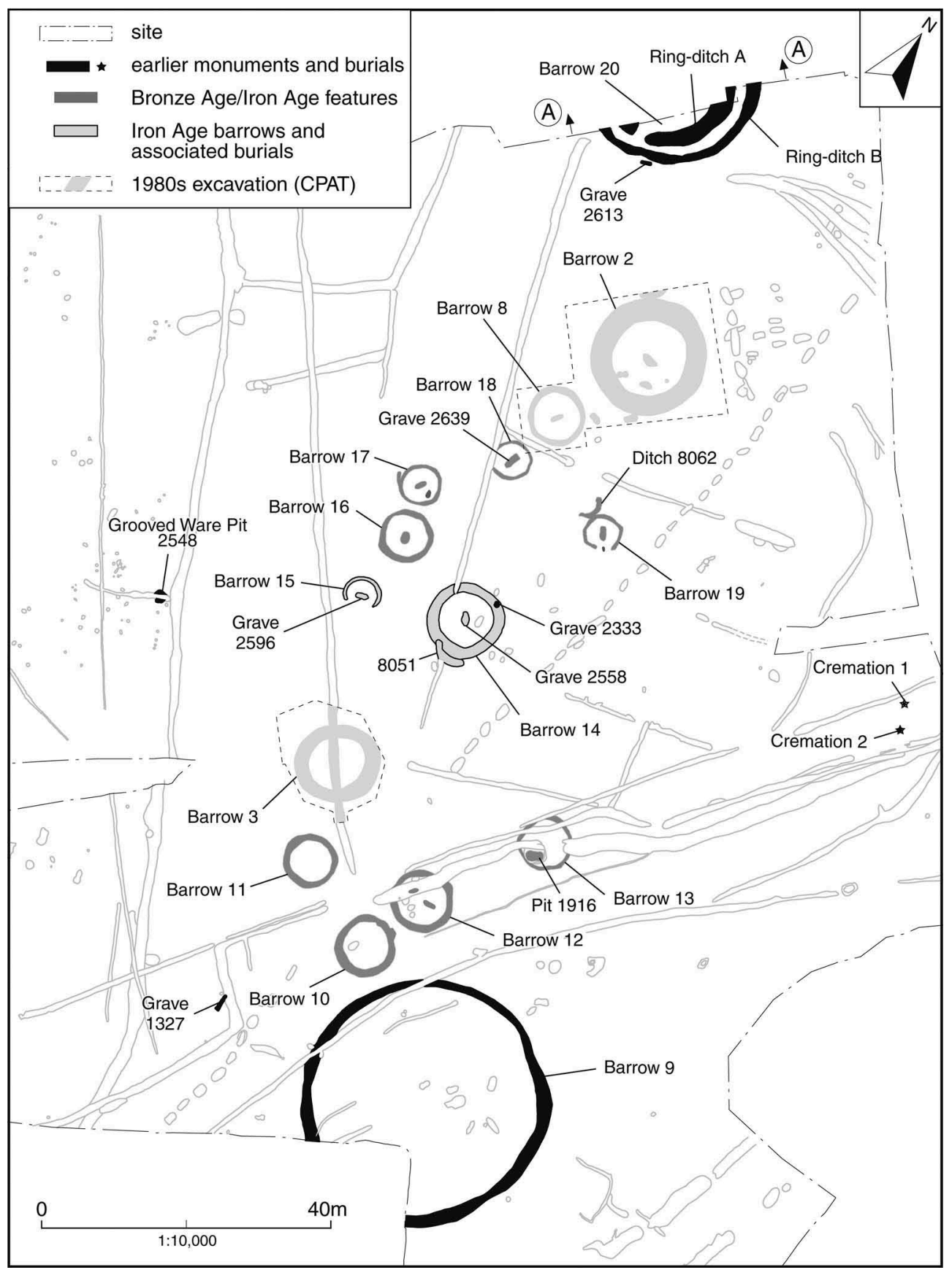

ILLUS. 2 The barrow cemetery and burials 
FOUR CROSSES, LLANDYSILIO

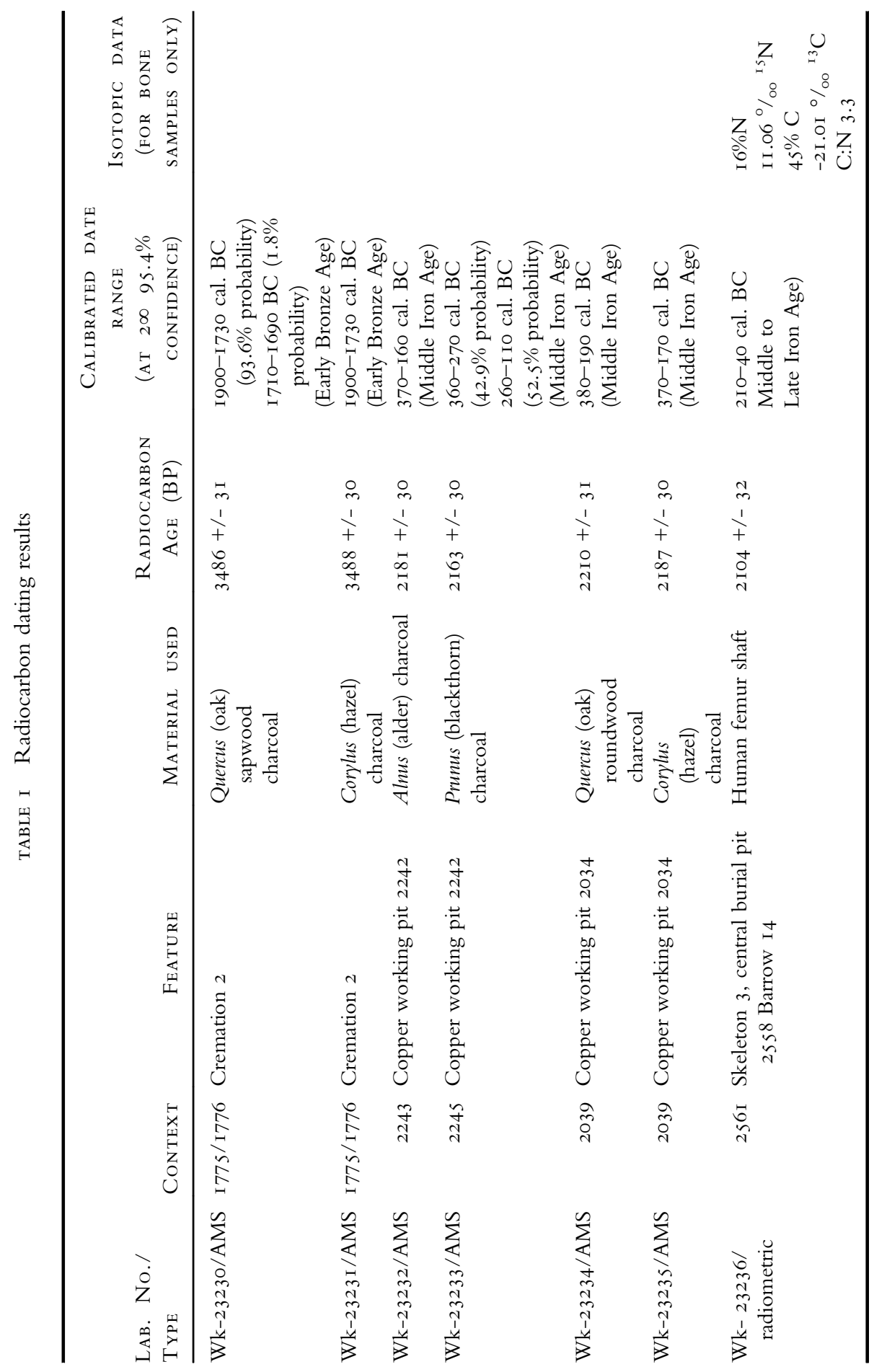


earthworks into later periods. The north-south axis of the barrows was followed by the principle pit alignment (Pit Alignment I) which also ran through the central area of the site and was interrupted where it crossed the barrows. On the south-east side of the excavated area an undated trackway ran on a similar alignment. The Neolithic pit and main concentration of copper-working activity were situated on the west side of the barrow zone. More scattered evidence for copper working was found to the west and within the perimeter of the southernmost ring ditch. The Romano-British field system imposed a different alignment across the area although gaps in the field ditches suggest some of the barrow monuments were still visible. The location of a small RomanoBritish or later cemetery close to one of the larger barrows (Barrow 2) would appear to be a deliberate reference to the significance of the earlier monument.

\section{GROOVED WARE PIT}

A single sub-circular pit 2548 , measuring $\mathrm{I} .5 \mathrm{~m}$ in diameter and $0.5 \mathrm{~m}$ in depth lay in the west side of the site (Illus. 2). It contained a single fill, from which twenty-eight sherds of a single Grooved Ware vessel of Late Neolithic date were recovered. The sherds were large and unabraded, and some showed thick sooting on their outer surfaces. No other materials were recovered from the pit which was partly truncated by a later Roman-period ditch.

\section{THE BARROW CEMETERY AND BURIALS}

Evidence for monuments and burials of the barrow cemetery within the excavation area comprised twelve ring ditches or barrows, at least six associated graves and two unurned cremations (Illus. 2). The barrows excavated in 2004-6 were numbered 9-20. Barrows 2, 3 and 8 excavated in the I980s also lay within the excavated area. Barrows 2, 3, 9, I0 and I 4 were previously known from aerial photography, whilst I 6 and 20 were first discovered by geophysics. Barrow 8 was investigated by CPAT in the I980s and barrows II, I2, I3, I5, I7, I 8 and I9 were only found by excavation, presumably because they were too shallow or slight to produce good cropmarks or geophysical readings. Dating evidence from the previously excavated barrows was equivocal, but on balance the Beaker period or Early Bronze Age was considered the most probable date for construction. Dating evidence from the 2004-6 was similarly sparse: one cremation approximately $50 \mathrm{~m}$ from the barrows returned an early Bronze Age radiocarbon date, and a Bronze Age date is suggested for the isolated burial 1327 , whilst dating from two of the smaller barrows (Barrows I 4 and I 5 ) suggest the construction of funerary barrows continued into Iron Age. The evidence implies a long sequence of monument building and associated funerary/ritual activity spanning two millennia or more, but precision over the sequence of monument building, burial and reuse is not possible. The cemetery features are described from south to north.

\section{BARROW 9 AND GRAVE I 327}

Barrow 9 was evident as a ring ditch in the south of the site, and measured approximately $35 \mathrm{~m}$ in diameter. On average the ditch measured $\mathrm{I} .35 \mathrm{~m}$ wide and $0.8 \mathrm{~m}$ deep and had steeply sloping sides with a pronounced notch at its base. There was no 
evidence for re-cutting. The thin, unmixed gravel-rich basal fills in the majority of ditch sections were most likely derived from gravel falling back into the ditch very soon after its construction. Subsequent ditch fills contained much higher proportions of silt which suggests gradual weathering and silting. There was no evidence for any deliberate backfilling, or to indicate on which side of the ditch a bank may have been situated. No dating evidence was recovered from any of the excavated ditch sections other than a single flint waste flake showing edge wear - broadly dated to the Late Neolithic or Bronze Age - which may be residual. The ring ditch was cut on its western side by a post-medieval ditch. Small amounts of charred plant remains were recovered from the fill of the ring ditch although none were suitable for radiocarbon dating.

The functional interpretation of this ring ditch is unclear, as upcast derived from the ditch, which enclosed a large area, would only have created a small mound or a low bank, if indeed either one existed. Several possible pit-like features internal to the ring ditch were investigated; all proved to be geological apart from oval pits I 766 and I796. Both pits contained evidence for copper working and were similar in their form and fills to other features dated to the Middle Iron Age from radiocarbon determinations. The ring ditch of Barrow 9 was considerably larger than the other ring ditches that form the barrow cemetery, and although it has been interpreted as a funerary monument it is also possible that the ring ditch was a feature associated with the metalworking activity.

Grave I327, lay I4 $\mathrm{m}$ to the west of Barrow 9, was rectangular in plan and measured $2.05 \mathrm{~m}$ in length, $0.95 \mathrm{~m}$ in width and $0.57 \mathrm{~m}$ in width. No bone survived within the grave, but a single amber bead recovered from the fill is stylistically of probable Bronze Age date. Root disturbance prevented any relationship being established with the adjacent post-medieval ditch.

\section{BARROWS IO-I 3}

Lying to the north of Barrow 9 was a cluster of four smaller barrows. The ring ditches of Barrows IO, II, I2 and I 3 measured between $7.4 \mathrm{~m}$ and $8 \mathrm{~m}$ in diameter; the varying widths (between $0.4 \mathrm{~m}$ and $\mathrm{I} \mathrm{m}$ ) and depths (between $0.2 \mathrm{~m}$ and $0.45 \mathrm{~m}$ ) of the ditches were due to truncation, possibly by later ploughing.

The fills of the ring ditches of these barrows were generally naturally deposited sandy silts with low to moderate amounts of gravel inclusions, and neither conclusively proving or disproving the presence of mounds interior to the ring ditches.

Two possible graves, located in the interior of Barrow I2, were sub-rectangular in plan, measuring between I.5 $\mathrm{m}$ and $\mathrm{I} .9 \mathrm{~m}$ in length, between $0.65 \mathrm{~m}$ and $0.75 \mathrm{~m}$ in length and $0.3 \mathrm{~m}$ to $0.5 \mathrm{~m}$ in depth. Single fragments of charred remains of hazelnut shell and wheat were recovered from these two graves, however none of this material was suitable for radiocarbon dating. An intrusive modern calf burial was recorded inside Barrow Io whilst no features interior to Barrow I I were identified. Small quantities of charred plant remains were recovered from the ditches of both Barrow io and Barrow I I.

Pit I9i6 was cut through the silty fill of the ring ditch of Barrow I3 (Illus. 2). It measured $2.8 \mathrm{~m}$ in length, I. $8 \mathrm{~m}$ in width, $0.7 \mathrm{~m}$ in depth, was ovoid in plan and had steep sides which became vertical towards the base of the pit. It was left open and silt accumulated in its base before the deliberate deposition of layer I9I 8, a distinct brown- 
black layer containing wheat, knotweed, legume and a comparatively large quantity of hawthorn and willow charcoal. No skeletal remains were recovered from this deposit which was then sealed when pit I9I6 was deliberately back-filled. Two unidentified animal bones and a single horse bone fragment were recovered from the pit fills.

\section{B A RROW I 4}

Barrow I4 was distinct in character compared to many of the adjacent barrows being slightly larger in size and with a wider ditch. The ring ditch measured $\mathrm{Io} \mathrm{m}$ in diameter, with the ditch having steeply sloping sides, a concave base and measuring between I.3 $\mathrm{m}$ and $\mathrm{I} .5 \mathrm{~m}$ in width and between 0.45 and $0.7 \mathrm{~m}$ in depth (Illus 3 and 4 ). The larger width of this ditch in comparison to the adjacent ring ditches might suggest the upcast was used to create a bowl barrow that extended to the inner lip of the ditch. The higher proportion of gravel in the primary fills of the ditch compared to other ring ditches on the site suggests the mound was slumping or eroding into the ring ditch. The siltier secondary fill of the ditch accumulated when this process slowed, once a stable surface had formed over the mound. The erosion of the mound, however, seemed to have continued on the southern side where re-cut $805 \mathrm{I}$ may have provided upcast for a repair. On the north side of the barrow, the ring ditch had heavily truncated an earlier grave 2333 which contained the inhumation burial (Skeleton I/2) of a mature adult, possibly a male oriented north-west to south-east. Grave 2558, located centrally within Barrow I4, contained an adult inhumation burial (Skeleton 3) of which only leg bones and two molar crowns survived. The femur produced a radiocarbon date of $2 \mathrm{IO}-40 \mathrm{cal}$. $\mathrm{BC}$ (Wk-23236). If this burial is assumed to be the primary burial of the mound, and not a later insertion, this places the barrow in the Iron Age.

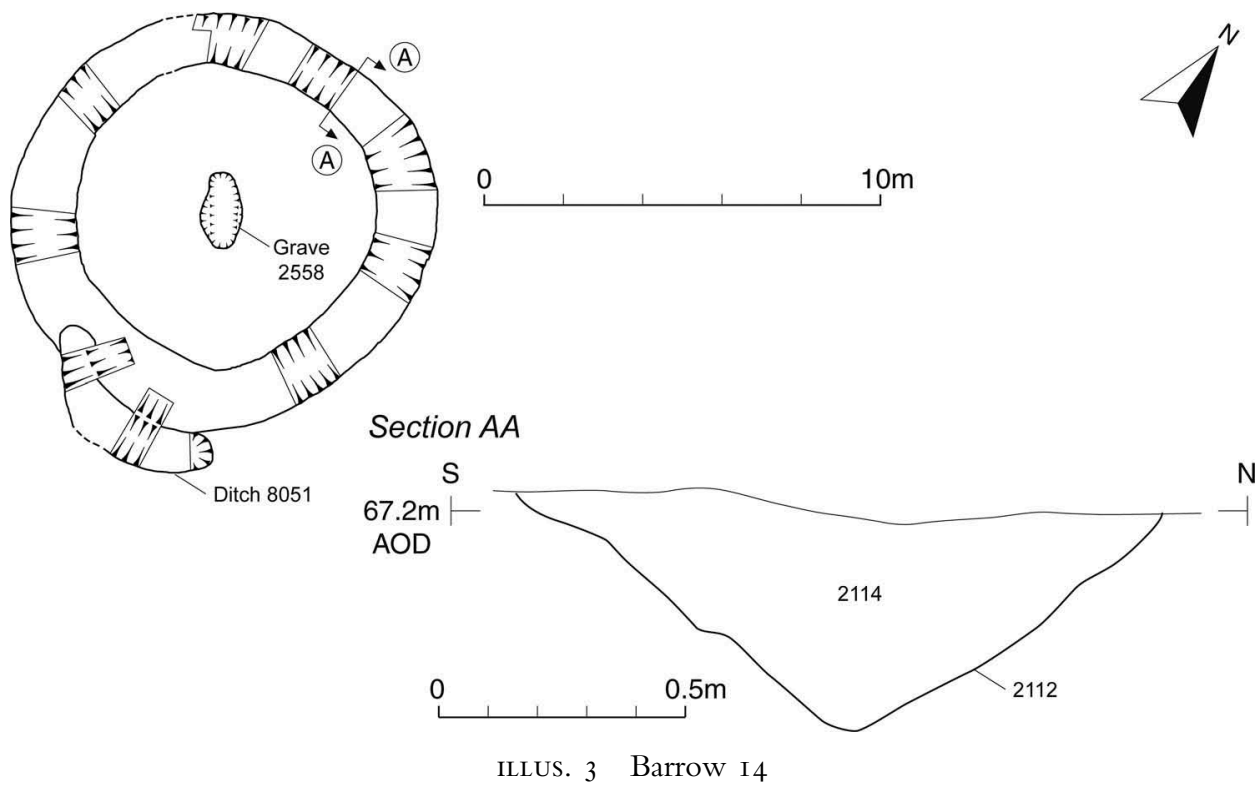




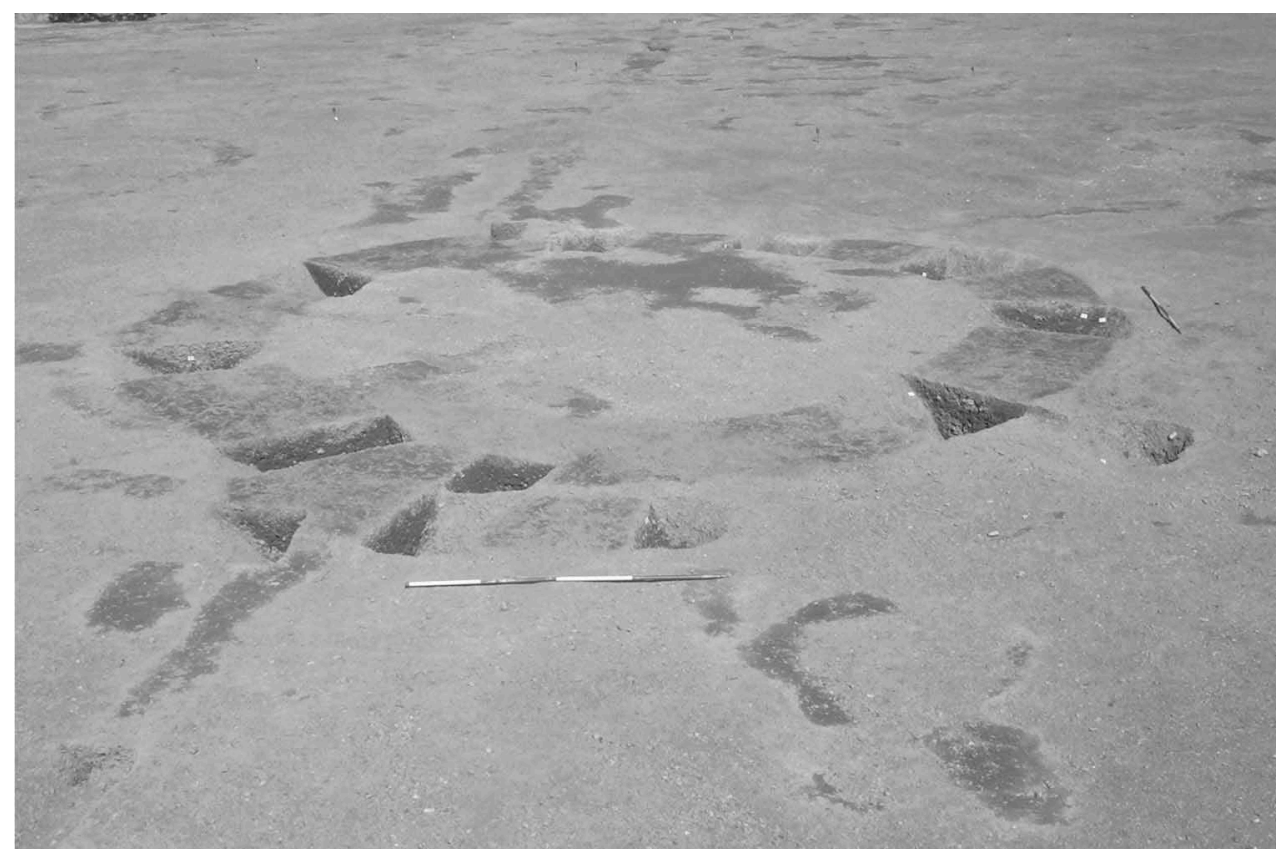

ILLUS. 4 Barrow I4 looking north-west

BARROWS I 5-I 9

Barrows I 5-I9 formed a second cluster of smaller barrows located between Barrows 3 (excavated by CPAT) and $\mathrm{I} 4$ to the south, and Barrow 2 (excavated by CPAT) to the north. The ring ditches of Barrows I5, I6, I7, I 8 and I9 were similar to Barrows IO-I 3 to the south but slightly smaller, with diameters in the range of $5.5 \mathrm{~m}$ to $7.5 \mathrm{~m}$.(Illus 5,6 and 7). A short stretch of curvilinear ditch 8062, lay immediately to the north-west of, and was cut by, Barrow I9. The ditch measured $4 \mathrm{~m}$ in length and up to $0.6 \mathrm{~m}$ in depth, had an irregular ' $u$ '-shaped profile and contained a single undated silty fill. This may have been the remnant of an earlier ring ditch. It is possible that the gap in the ring ditch of Barrow I9 represented an entrance although it is more likely this was due to truncation, probably by ploughing.

The ring ditch of Barrow I5, like the ring ditch of Barrow I9, did not survive as a continuous circuit (Illus. 2). Here, the gap was too wide to be an entrance, and is almost certainly the consequence of later agricultural activity, which had truncated the surviving ditch to no more than $0.2 \mathrm{~m}$ in places.

A small quantity of bone of an adult survived in grave 2639 in the interior of Barrow I 8 but was not suitable for radiocarbon dating. A copper-alloy finger ring (Illus. I6, I), was recovered from the fill of grave 2596 located centrally within Barrow I 5 , although no human remains survived. The ring is Iron Age in both its style and its composition (leaded bronze) (see McSloy below). Probable graves were also identified in the interior of Barrows I6, I7 and I9 although no finds or human remains were recovered from any 


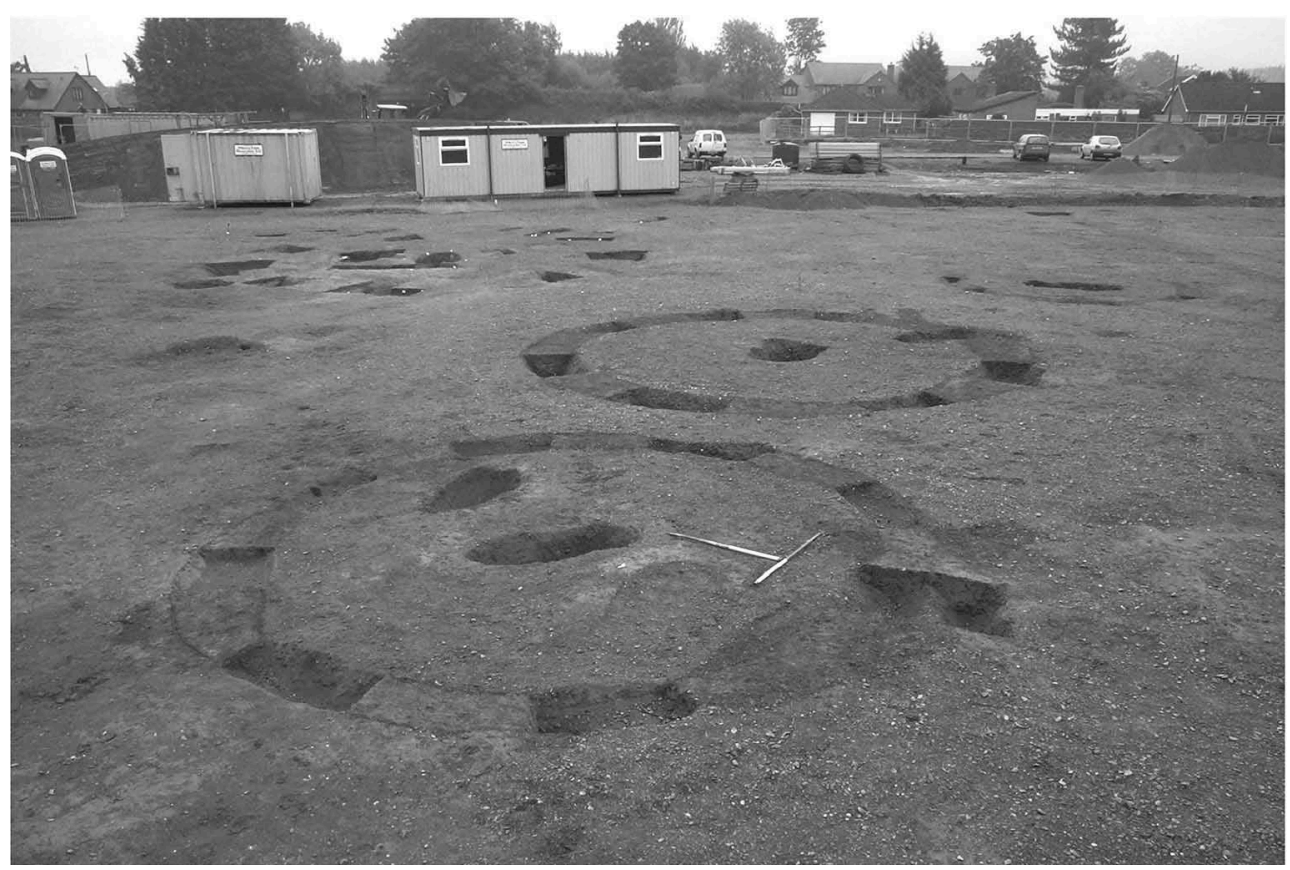

ILLUS. 5 Barrow I7 in the foreground looking south towards Barrows I4, I5 and I6

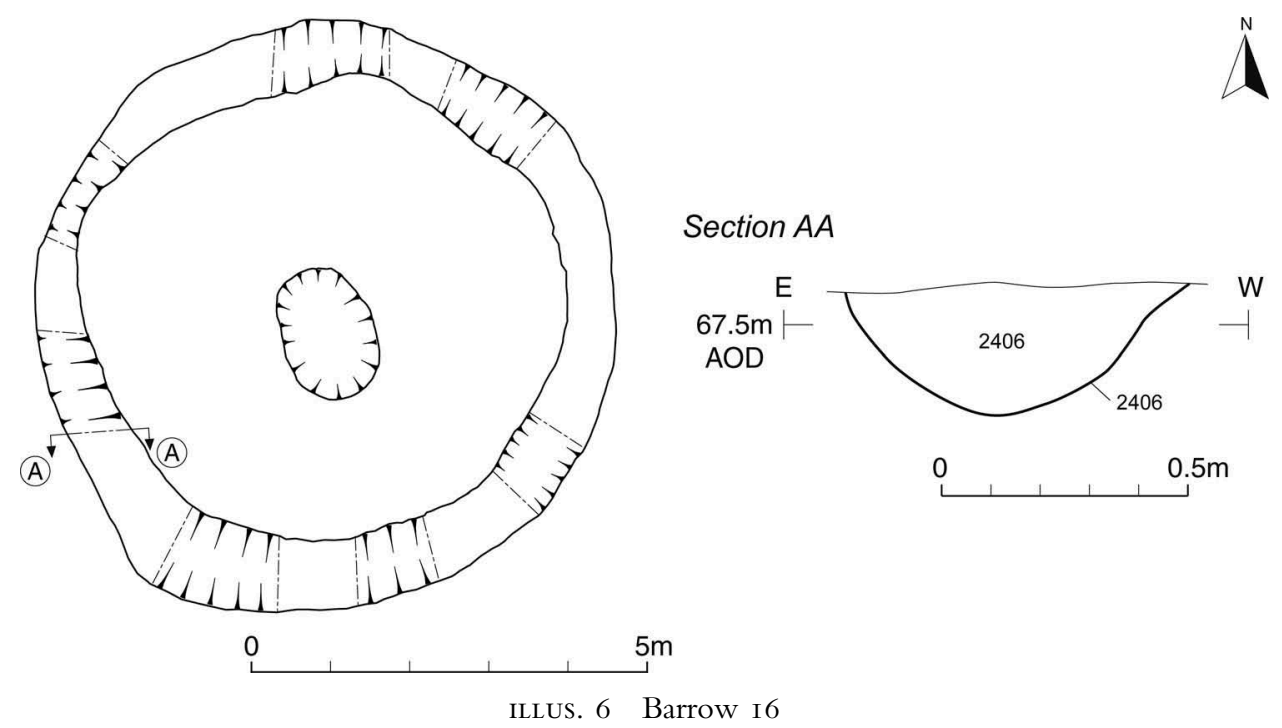




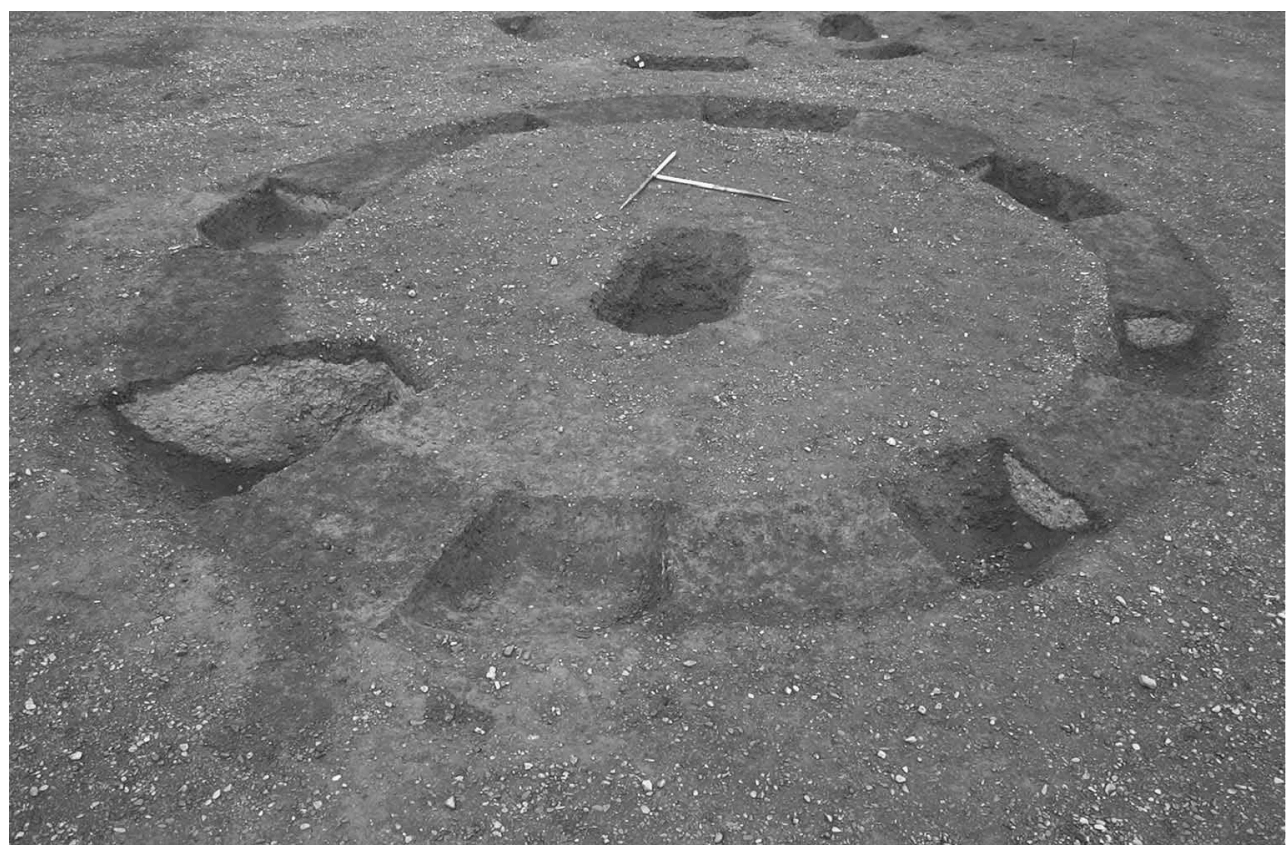

ILLUS. 7 Barrow I6 looking north-west.

of them. The shape and size of these graves was generally indicative of tightly flexed inhumations, although a smaller grave on the eastern interior side of Barrow I7 was perhaps more suggestive of a crouched inhumation. These graves had all been backfilled with the gravel upcast produced when they were cut.

\section{BARROW 20 AND GRAVE 26 I 3}

Barrow 20 lay at the northern edge of the excavation, and thus only partially within the excavated area. A buried subsoil and elements of a buried topsoil survived beneath the mound material of the barrow. The buried topsoil was relatively shallow, measuring only $0.08 \mathrm{~m}$ in depth, and micromorphological analysis suggested that the upper horizon had been removed some time before barrow construction. Ring Ditch A cut through the buried deposits and enclosed an area at least Io $\mathrm{m}$ in diameter and measured between I.9 $\mathrm{m}$ to $2.5 \mathrm{~m}$ in width and about $\mathrm{I} .2 \mathrm{~m}$ in depth (Illus $2,8-\mathrm{IO}$ ). The ditch was not a continuous circuit, as a causeway was recorded within the excavation area. Gravel, derived from the cutting of the ditch, formed a primary mound which measured around $8 \mathrm{~m}$ in diameter and extended to the inner lip of Ring Ditch A. An original mound height of around $2 \mathrm{~m}$ can be inferred from the section (Illus. IO). A probable pit, 3025, was cut into the primary mound soon after construction and seen in section only. After initial erosion of the sides, the pit had been deliberately back-filled with the material it had been cut through, and was sealed by the earliest layer of erosion of the primary mound. Numerous small-scale episodes of gravel slumping from the 


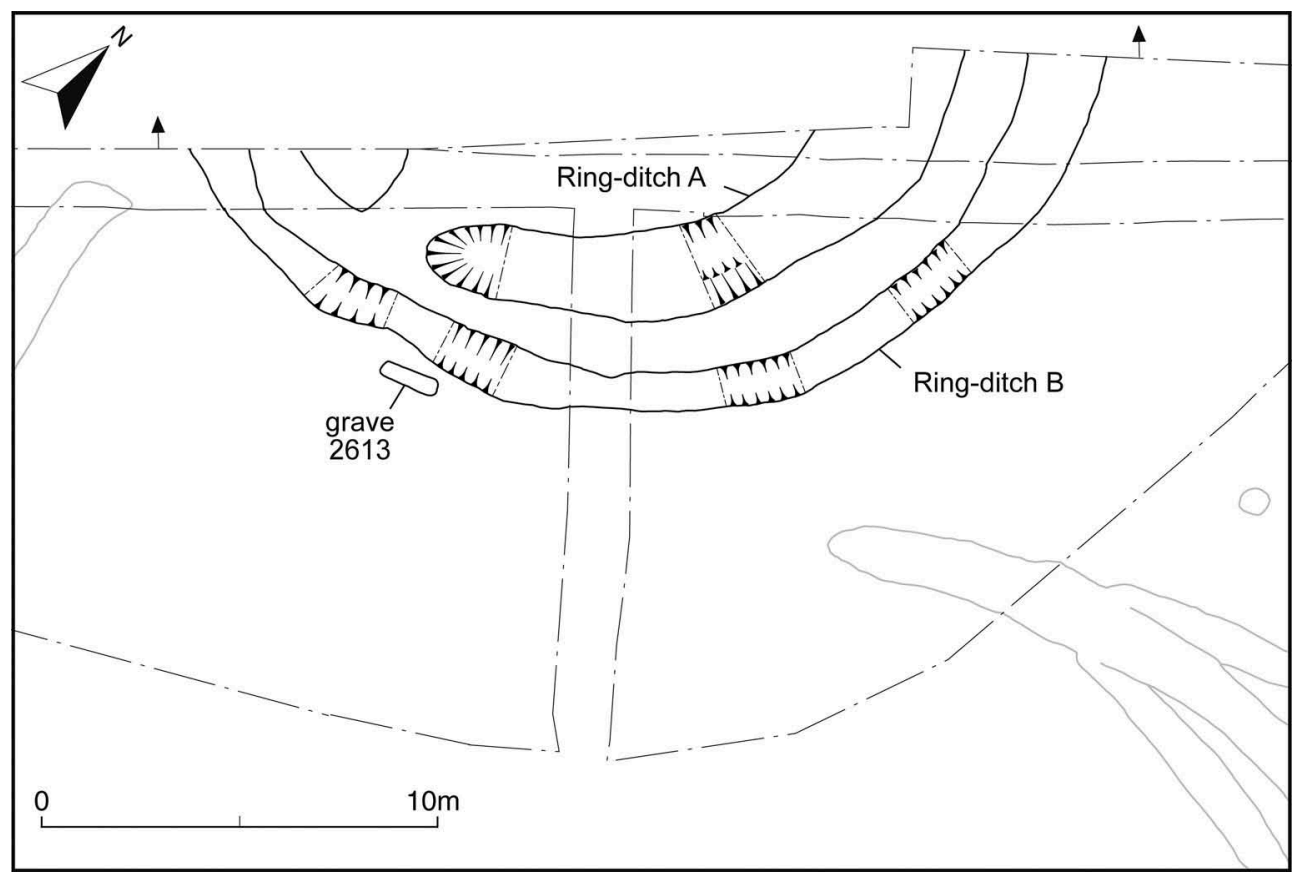

ILlUS. 8 Barrow 20

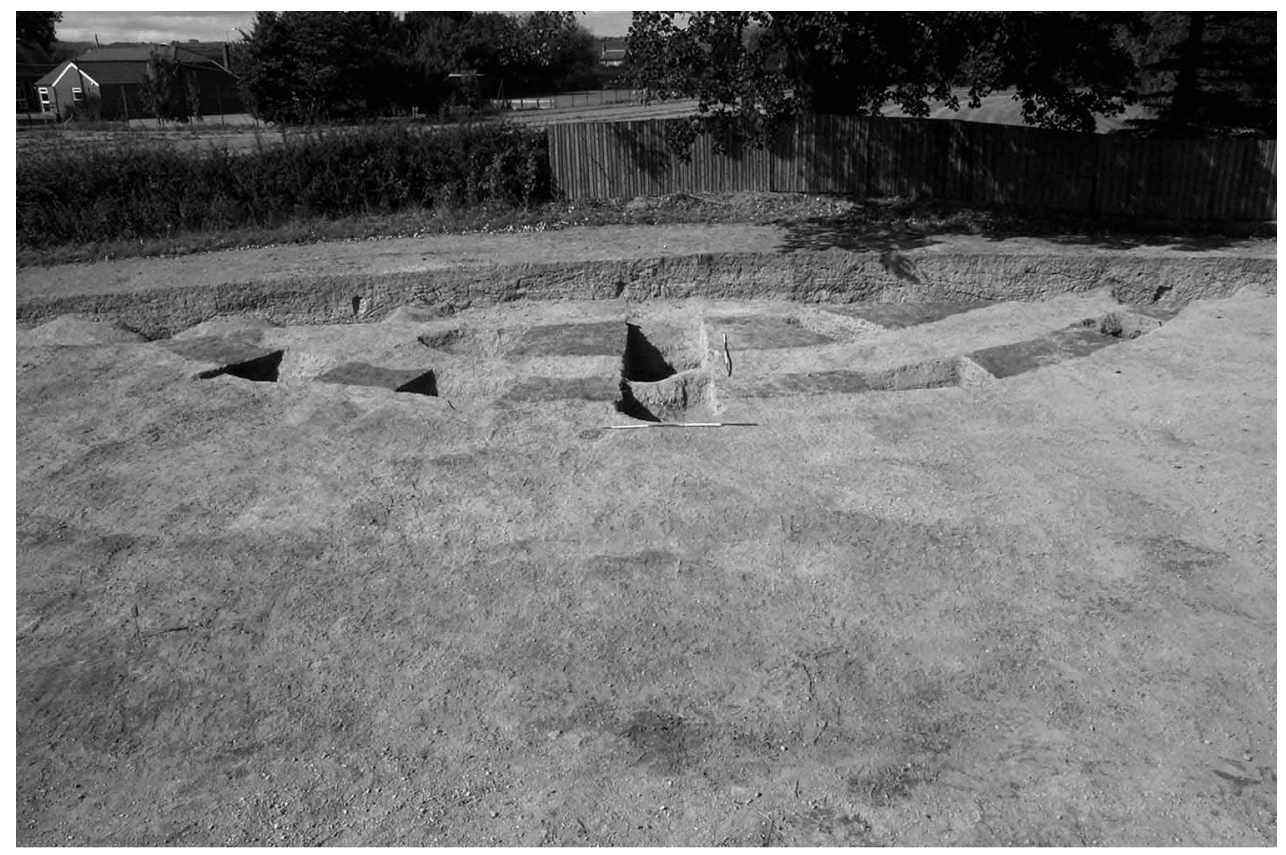

ILLUS. 9 Barrow 20 Looking north-west 


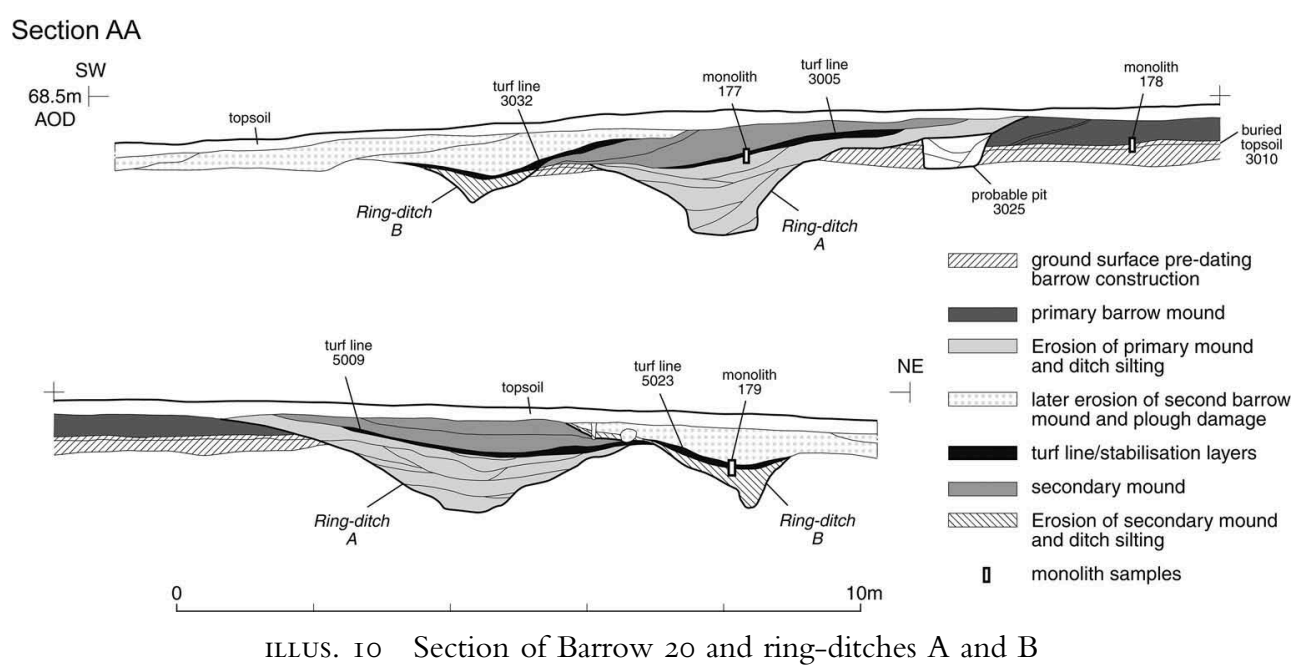

primary mound and silting combined to in-fill and level Ring Ditch A. The final deposit in this sequence was a thin layer of whitish grey clay (3005 and 5009) interpreted as a turf line. The turf had formed over the in-filled ditch once erosion from the primary mound had ceased.

Construction of the secondary mound began with the cutting of Ring Ditch B. The ditch enclosed an area approximately I $8 \mathrm{~m}$ in diameter and measured between I.I $\mathrm{m}$ and $\mathrm{I} .8 \mathrm{~m}$ in width and $0.6 \mathrm{~m}$ in depth. The eastern half of the ring ditch was observed within the excavation area as a continuous feature encircling Ring Ditch A. The gravel upcast derived from Ring Ditch B was deposited over the primary mound and the turf line above the in-filled ditch of Ring Ditch A to create a larger secondary mound. Geoarchaeological analysis suggested that the upper horizon of the turf line had been truncated, although the lower horizon showed features of a mature soil. An episode of burning may be represented by inclusions of charcoal fragments and the magnetic readings from this soil profile (see Wilkinson and Lewis, this article). This might indicate the clearance of vegetation and levelling before the secondary mound was constructed, although the timespan between the two phases of barrow construction is uncertain. The secondary mound was enhanced by soil stripped from the exterior of Ring Ditch B to create a mound at least $\mathrm{I} 8 \mathrm{~m}$ in diameter which, as with the primary mound, extended to the inner lip of the ditch. The outer ring ditch was filled with erosion materials from the secondary mound and silting. This was sealed by a thin layer of whitish grey clay (3032 and 5023), again interpreted as a turf line (Illus. IO). No dating evidence was recovered from either the primary or secondary mound or the fills of ring ditches A and $\mathrm{B}$.

Grave 26I3 was rectangular in plan and measured $\mathrm{I} .4 \mathrm{~m}$ in length, $0.5 \mathrm{~m}$ in width and $0.1 \mathrm{~m}$ in depth. It contained a poorly preserved supine inhumation burial of an adult, possibly female (Skeleton 5), and lay immediately to the exterior of Barrow 20 (Illus 2 and 8 ) and was sealed by later erosion of the secondary mound. 
Two unurned cremation burials were recorded in the east of the excavation (Illus. 2). Cremation 2 was circular in plan, measuring $0.5 \mathrm{~m}$ in diameter and $0.27 \mathrm{~m}$ in depth. It contained the cremated bone (fill I777/I 778) of an adult, possibly female, which had been placed in the base of a grave pit which was then back-filled with a charcoal-rich fill I775/I776, presumably derived from pyre debris. Charcoal of oak and hazel from the pyre debris produced a radiocarbon date of I900-I730 cal. BC (Wk- 23230, Wk$2323 \mathrm{I})$. Cremation I lay $4 \mathrm{~m}$ to the south, in a circular pit of similar dimensions with a single fill I733. The cremated bone from Cremation I (recorded as I732), which was unidentifiable to age or gender, was not suitable for radiocarbon dating but its proximity to Cremation 2, suggests a similar date.

\section{PIT ALIGNMENTS AND IRON AGE BURIALS}

Pit Alignment I ran across the centre of the site on a north-south alignment (Illus. I I) for a length of at least I $50 \mathrm{~m}$ and was probably the continuation of a cropmark pit alignment which approached the site from the north. It comprised thirty-three pits which were generally ovoid in shape with the long axis along the alignment. The dimensions of the pits varied between $1.6 \mathrm{~m}$ and $2.5 \mathrm{~m}$ in length, averaged $0.33 \mathrm{~m}$ in depth, and were set I $\mathrm{m}$ apart from each other on average. The pits had all in-filled naturally with sandy silts with rare gravel inclusions with no evidence for any maintenance or back-filling, or to indicate which side any bank may have been situated. A Middle Iron Age date was obtained from Cremation Burial 3, although the cremated bone may be residual and no further dating evidence was recovered from any of the pits, other than a single flint waste flake. A gap in the alignment respected Barrow 3 and Barrows IO, II and I2, and two pits of the alignment were cut by ditches of the Romano-British field system.

Cremation Burial 3 produced just $3 \mathrm{~g}$ of cremated bone. Charcoal recovered during the 2003 evaluation from the same feature produced a Middle Iron Age radiocarbon

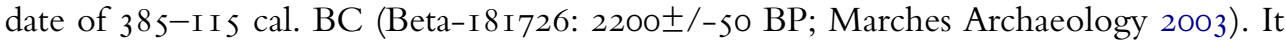
was not possible to establish if Cremation Burial 3 was residual material re-deposited during the construction of this pit alignment, or was a deliberate burial in the pit alignment.

Grave 2648 measured I. $55 \mathrm{~m}$ in length, $0.76 \mathrm{~m}$ in width and $0.5 \mathrm{~m}$ in depth and contained a single silt gravel fill. The grave had been partially uncovered during the earlier evaluation, and contained a poorly preserved inhumation burial of an adult, possibly male (Skeleton 7). It was immediately adjacent to and aligned parallel with Pit Alignment I, suggesting that it may have been contemporary. A further pit alignment (2) ran for a length of approximately I $6 \mathrm{~m}$ in a south-east-north-west direction from Pit Alignment $\mathrm{I}$, in the direction of Barrow 20. The pits were sub-rectangular in plan, between $2 \mathrm{~m}$ and $3.5 \mathrm{~m}$ in length and between $0.42 \mathrm{~m}$ and $0.6 \mathrm{~m}$ in depth with the long axis along the alignment. There was no evidence for any deliberate back-filling of the pits (which contained silty sand fills with few gravel inclusions), or to suggest on which side any bank may have been. No dating evidence was recovered from the pits and there was no stratigraphic relationship with the adjacent Romano-British cemetery 


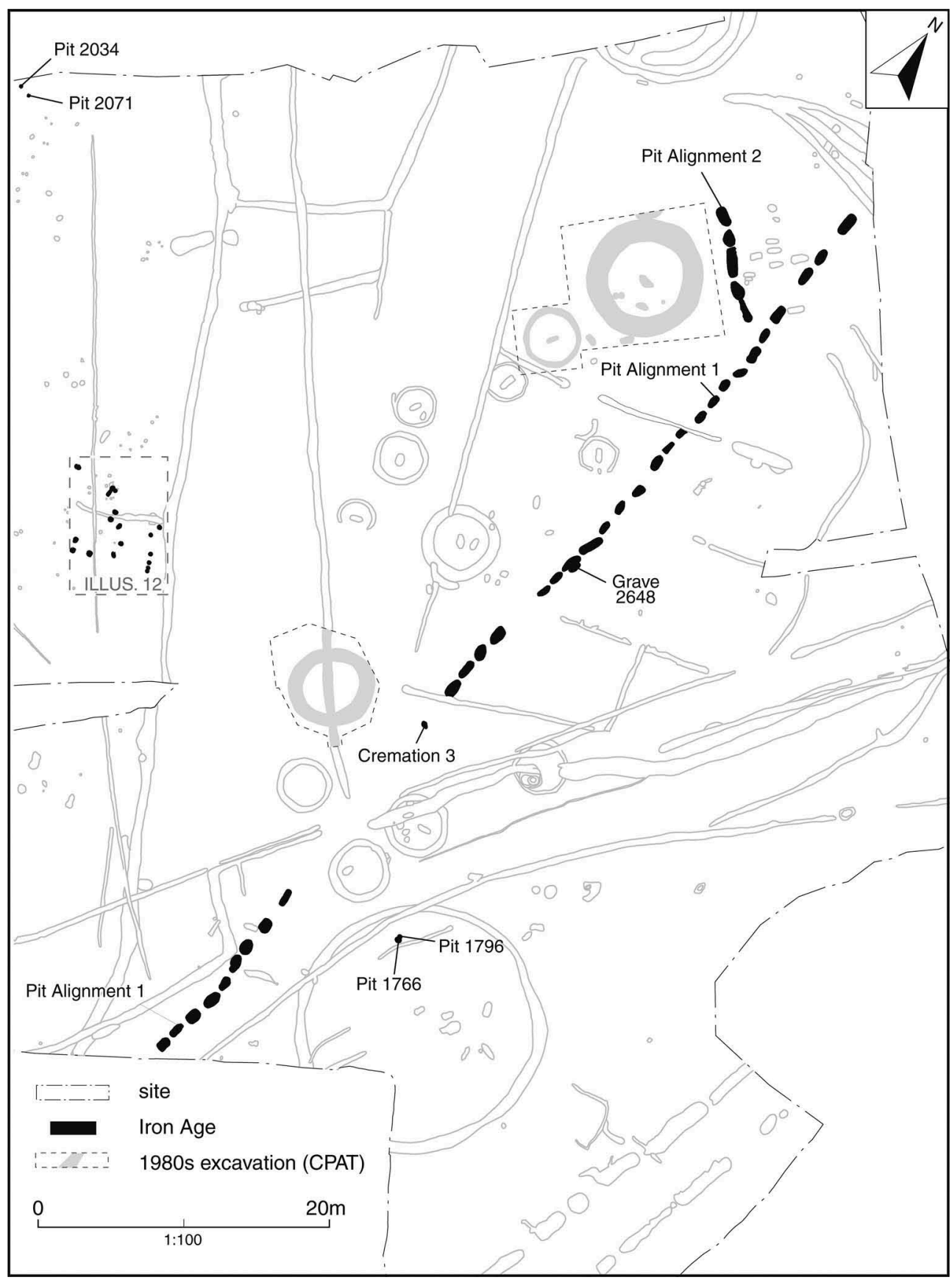

ILLUS. I I Iron Age copper working and pit alignments 
(see Illus. I4). Pit Alignment 2 was located immediately to the north of Barrow 2 suggesting the latter was still extant at the time this pit alignment was established.

\section{TR A C K W A Y}

The trackway was recorded in the south-east of the site and was aligned north-east to south-west. It comprised two parallel lines of discontinuous butt-ended ditch segments, which were generally sub-rectangular in plan and which measured between $4 \mathrm{~m}$ and Io $\mathrm{m}$ in length, between I.I $\mathrm{m}$ and 2.I $\mathrm{m}$ in width and between $0.37 \mathrm{~m}$ and $0.5 \mathrm{I} \mathrm{m}$ in depth. The bank was likely to have been located on the exterior of the trackway although this was not reflected in the silty clay fills recorded in the excavated sections, nor was there any evidence of any deliberate back-filling. No dating evidence was recovered from the trackway ditches which were different in form from the pits of the pit alignments I and 2 although the similarity in alignment of the trackway and Pit Alignment I raises the possibility that they are contemporary.

\section{IRON AGE COPPER WORKING}

Copper smelting waste material was recovered from a series of small pits truncated by ploughing, two of which produced Middle Iron Age dating evidence. These features occurred in three groups: two pits (I766 and I796) in the south-west of the site, within Barrow 9 (Illus. II), a central group of pits in the west of the site (Illus. I2) and two outlying pits (2034 and 207I) in the north-west of the site. The waste material recovered comprised reduced-fired furnace lining fragments, a fragment of block tuyère and small quantities of slag, ore and copper prills. The waste material is discussed further by Young below.

Within the central group of pits, six probable furnace pits, irregularly spaced, formed a north-west/south-east alignment approximately $6 \mathrm{~m}$ long. The majority had vertical sides and a flat base. Pits 22 I0, 2272 (Illus. I3), 2290 and 23 I 3 were circular, or slightly oval and measured between $0.23 \mathrm{~m}$ and $0.36 \mathrm{~m}$ in diameter, and up to 0.1 $5 \mathrm{~m}$ in depth. Pits 228 I and 2297 were irregular in plan but similar in size. The sides of all pits but 23 I 3 showed discolouration by burning, and a layer of charcoal was found at the base of pits 22 IO, 2272 and 2297. The fills contained charcoal, copper smelting slag and fragments of the fired clay furnace linings.

A cluster of three probable furnaces 2219,2242 and 2252 lay approximately $7 \mathrm{~m}$ to the west of this alignment with an associated pit 2257. Pit 22 I9 was distinctly rectangular in plan measuring $0.70 \mathrm{~m}$ by $0.25 \mathrm{~m}$ and contained a charcoal-rich primary fill that lapped up to the top of the edge of the cut, but dipped away in the middle where it had been partially cleaned out. Pit 2242 was circular in plan with steep sides and a flat base and measured $0.3 \mathrm{~m}$ in diameter and $0.2 \mathrm{~m}$ in depth. Three pieces of block tuyère recovered from the primary fill $2243 / 2245$ of pit 2242 were not in situ. Both the primary fill and secondary fill 2242 had been dumped into the open pit. Charcoal recovered from the primary fill 2243/2245 produced a Middle Iron Age radiocarbon date range of 370-I Io cal. BC (Wk-23232, Wk-23233) from alder charcoal and blackthorn charcoal. Pit 2373 lay to the west of this cluster and was the only feature that contained possible in situ evidence of copper smelting. It was sub-rectangular in plan 


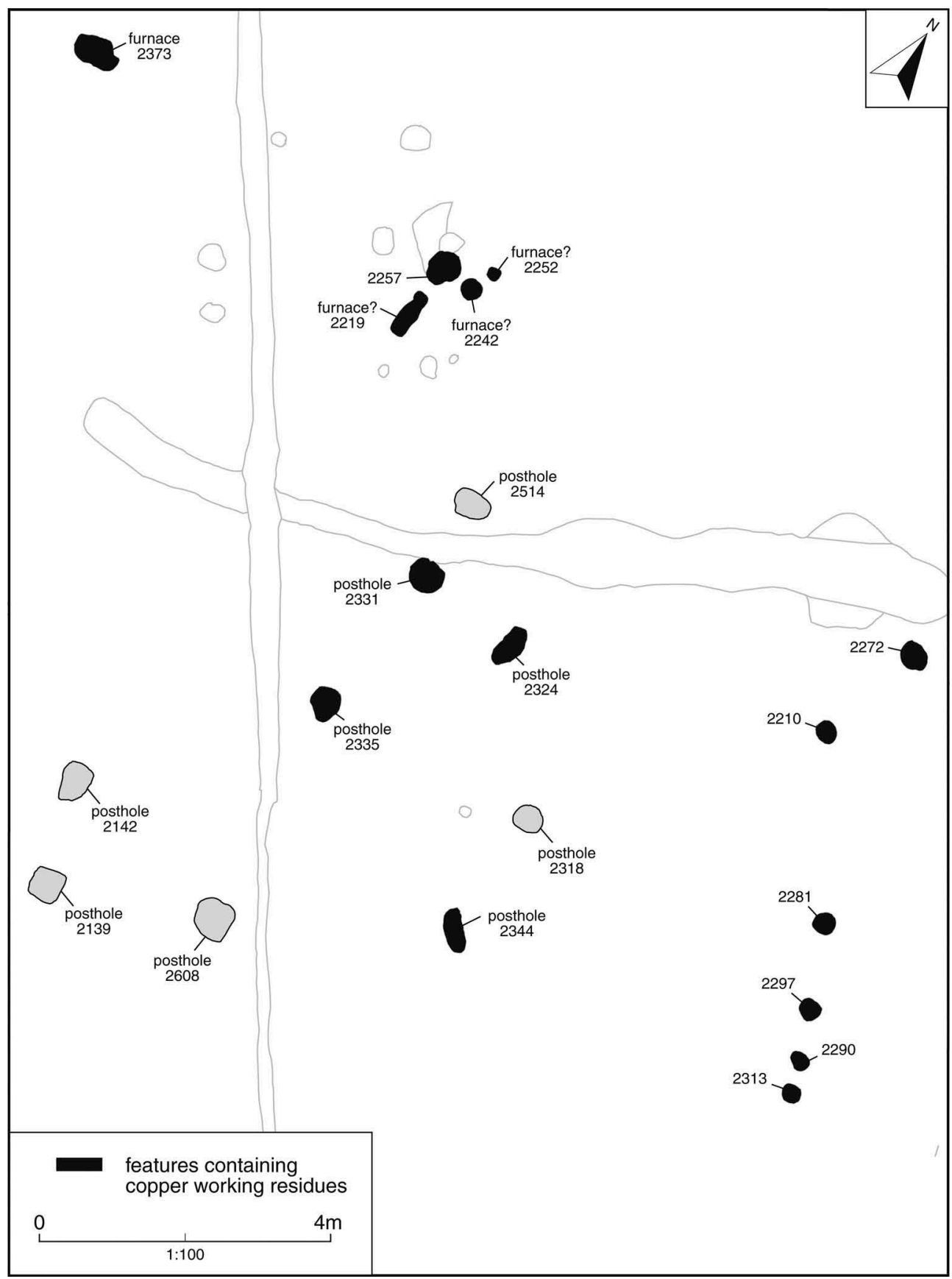

ILLUS. I2 Pits and post-holes containing copper and working residues 


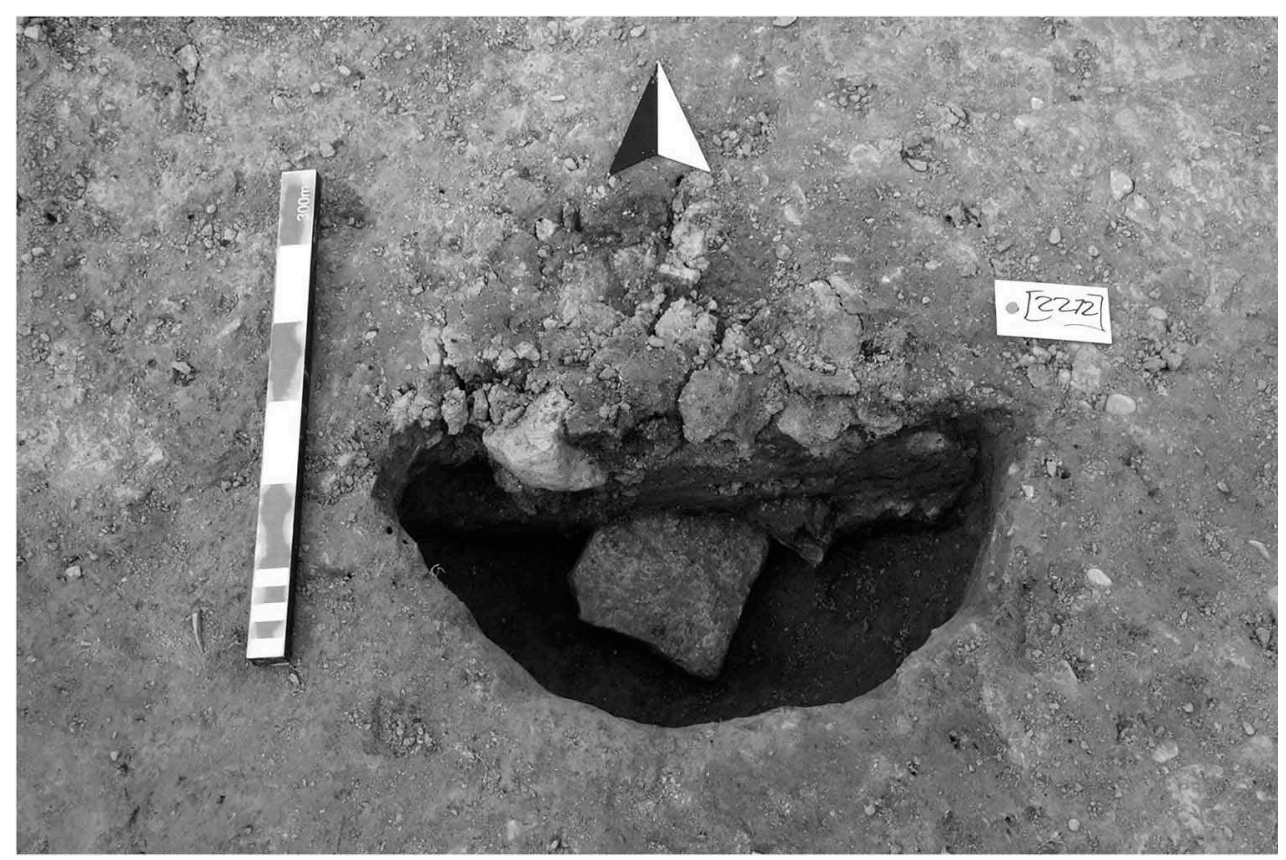

ILLUS. I 3 Smelting Pit 2272 looking north

with rounded corners and measured $0.6 \mathrm{~m}$ in length, $0.32 \mathrm{~m}$ in width and $0.08 \mathrm{~m}$ in depth. Fired clay in the base of the cut formed two sides of a square from which the majority of the metalworking residue $2374 / 2375$ was recovered, although the degree of truncation of this feature meant it could not be determined if this fired clay was in situ or not.

A possible structure to the south of this cluster is suggested by post-holes $25 \mathrm{I} 4,2324$, 23I8, 2344, 2608, 2I 39, 2I42, 2335, and 233 I. Post-holes 233I, 2324, 2335, 2 I 39 and $2 \mathrm{I} 42$ contained stone post-packing. The form of this structure was difficult to discern, it may have represented a small rectangular shelter associated with the copper working; two adjacent later ditches may have removed other post-holes. No dated material was obtained from these features, although post-holes 2324, 233 I, 2335 and 2344 contained copper working residues.

Copper smelting residues were recovered from two shallow oval pits I766 and I796 which measured between $0.35 \mathrm{~m}$ and $0.5 \mathrm{~m}$ in diameter and were located within Barrow 9 in very close proximity to each other. The pits were of similar dimensions to the main cluster; the edge of pit I 796 was scorched, and both contained copper slag and burnt clay. Such residues were also recovered from the fills of pits 2034 and 207I in the north-western corner of the site. These features preserved evidence of a clay lining and are interpreted as the truncated base of furnaces, surviving to a depth no greater than O.I 2 m. Fill 2039 (of 2034) produced a Middle Iron Age radiocarbon date of 370-I70 cal. BC (Wk-23234, Wk-23235) at 95.4\% probability from oak and hazel charcoal. 


\section{ROMANO-BRITISH FIELD SYSTEM AND CEMETERY}

\section{ENCLOSURE AND FIELD SYSTEM}

A rectilinear ditched field and enclosure system was set out across the site in the Roman period (Illus. I4). Boundary Ditch I lay on a north-west/south-east alignment and was re-cut frequently along its length in a piecemeal fashion, and contained a small quantity of Severn Valley Ware of second-fourth-century AD date. Ditch 8080 appeared to pre-date Boundary Ditch I although such a stratigraphic relationship was likely caused by a re-cut of the larger ditch. It is more probable that Ditch 8080 represented a small sub-division of the area immediately to the west of Boundary Ditch I.

Enclosure I lay in the north-west of the site, aligned on the north-west-southeast Boundary Ditch I and enclosed an area of at least $30 \mathrm{~m}$ by $17 \mathrm{~m}$. The ditch varied in width between $0.8 \mathrm{~m}$ and $\mathrm{I} .3 \mathrm{~m}$ in width and $0.46 \mathrm{~m}$ to $0.6 \mathrm{~m}$ in depth. Enclosure 2, defined by two additional ditches which measured between $0.8 \mathrm{~m}$ and $1.75 \mathrm{~m}$ in width and an average of $0.45 \mathrm{~m}$ in depth, was a later addition to the southern side of Enclosure I and enclosed a smaller area of $23 \mathrm{~m}$ by Io $\mathrm{m}$. A small quantity of cremated adult human remains (Cremation 4), apparently unurned and of indeterminate sex together with pyre debris (contexts 2010 and 20II) appeared to have been tipped into the open ditch at the north-eastern extent of Enclosure I, whilst a stone disc-form spindle whorl of probable Roman date was retrieved from the southern extent of Enclosure I. No features internal to either enclosure could be defined, and as such they are most likely to have represented agricultural enclosures.

Field System I lay to the east of these enclosures and ditches, and was defined by a main north-south ditch which measured an average of $\mathrm{I} .05 \mathrm{~m}$ in width and $0.4 \mathrm{~m}$ in depth although it became slightly narrower and shallower towards its southern extent. Several east-west segmented ditches which lay to the east of this ditch defined small paddocks. These ditches generally measured between $0.5 \mathrm{~m}$ and I $\mathrm{m}$ in width and an average of $0.25 \mathrm{~m}$ in depth. One segment of the northernmost east/ west segmented ditch was much larger than the others and measured $\mathrm{I} .2 \mathrm{~m}$ in width and $0.6 \mathrm{~m}$ in depth. Although there was no sign of a re-cut within this segment it can be postulated that it represented a re-modelling of this part of the field system, perhaps to provide additional upcast for an adjacent bank. In none of the excavated sections of Field System I was there any suggestion as to which side any bank may have been located on. Possible post-holes, measuring no more than $0.2 \mathrm{~m}$ in diameter and depth were noted in one of the southernmost east-west aligned segments. The location of a gap, defined by butt-ended terminals, in the main north-south ditch and its northern terminus corresponded to the position of Barrows I4 and 20 respectively suggesting the associated barrow mounds were extant at the time of ditch construction. Field System I was dated by a single piece of Severn Valley Ware pottery recovered from the main north-south ditch; a piece of clay pipe stem also recovered is deemed intrusive. Although unconnected to the western complex of ditches, this system shared a similar alignment and is assumed to be part of the same pattern of land division. 


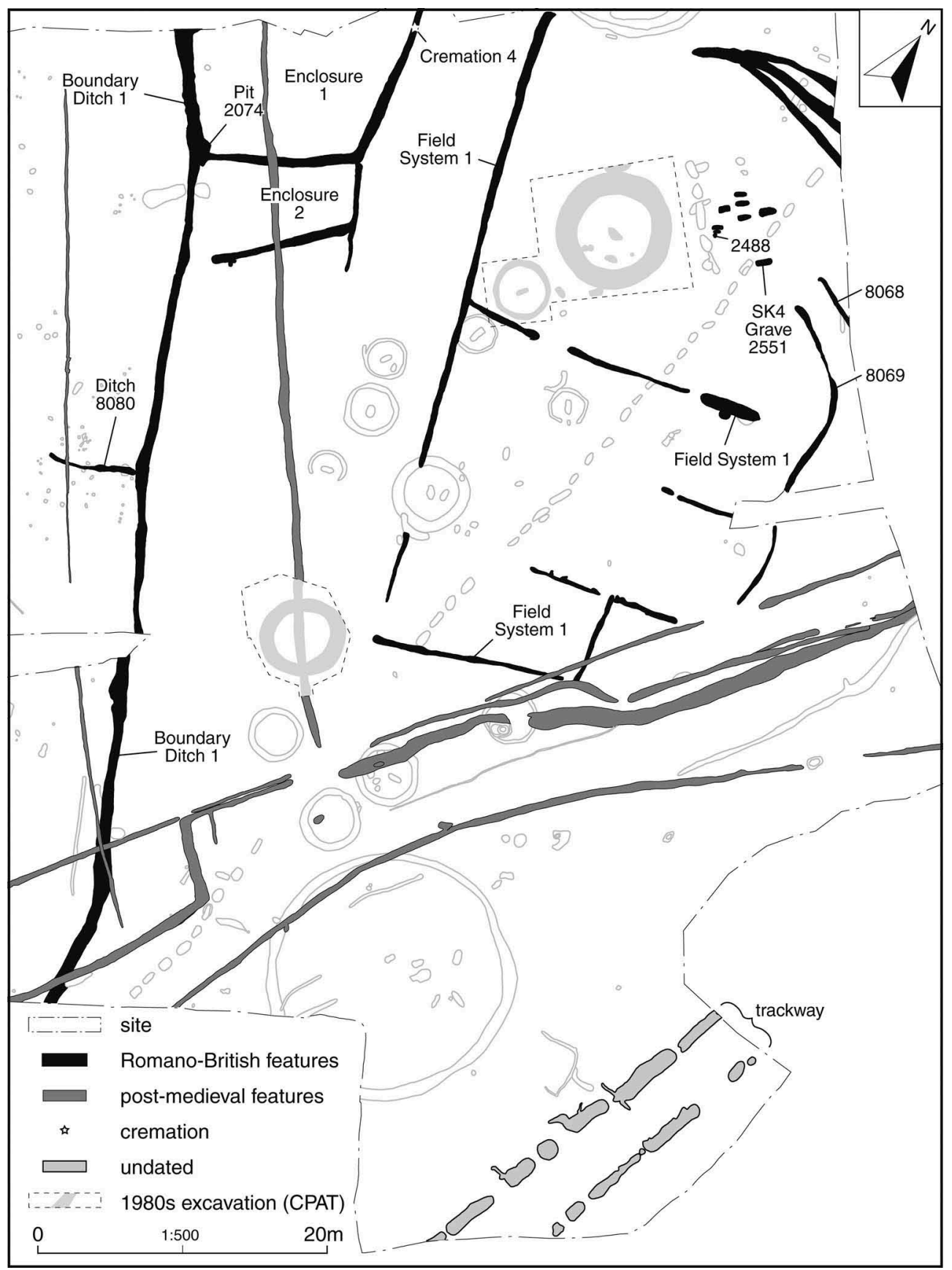

ILLUS. I4 Romano-British field system and cemetery, post-medieval features and undated trackway 
A small cemetery of eight inhumation burials was located in the northern part of the site. The graves were all approximately rectangular in plan on the same north-eastsouth-west alignment. Seven of them measured at least $1.5 \mathrm{~m}$ in length between $0.6 \mathrm{~m}$ and $\mathrm{I} \mathrm{m}$ in width and $0.2 \mathrm{~m}$ and $0.5 \mathrm{~m}$ in depth. An eighth, smaller, grave only measured $\mathrm{I} \mathrm{m}$ in length, $0.5 \mathrm{~m}$ in width and $0.18 \mathrm{~m}$ in depth. The very poorly preserved skeletal remains of an adult of indeterminate sex (Skeleton 4) survived in grave 255 I which also yielded several sherds of Romano-British pottery. This grave was set apart from the other graves which were comparatively closely packed lying no more than I.2 $\mathrm{m}$ apart from each other. No human remains survived in any other grave. A large stone-packed post-hole 2488 measuring $0.6 \mathrm{~m}$ in diameter and $0.4 \mathrm{~m}$ in depth, immediately adjacent to the smallest grave, may have represented a grave marker.

\section{CURVILINEAR DITCHES}

Three inter-cutting curvilinear ditches were recorded in the northern half of the site. These generally had steep sides and a narrow base and measured between $0.9 \mathrm{~m}$ and I.4 $\mathrm{m}$ in width and between $0.5 \mathrm{~m}$ and $0.8 \mathrm{~m}$ in depth. They had silted up naturally with no signs of on which side any bank may have been located. These were also of Roman date, a small quantity of second-century pottery was recovered from the southernmost of the three ditches, but did not obviously fit into the pattern of rectilinear fields and enclosures to the west. The ditches, together with ditches 8068 and 8069 to the south may define a trackway leading to the cemetery.

\section{THE POTTERY}

$$
\text { by ED MCSLOY }
$$

\section{NEOLITHIC AND BRONZE AGE}

Pottery of Neolithic and Bronze Age date occurred as Late Neolithic Grooved Ware from the fill of pit 2548 (location shown on Illus. 2) and an unstratified sherd, possibly of earlier Bronze Age date. Pit 2548 produced twenty-eight sherds (947 g) from a single Grooved Ware vessel (Illus. I5). The sherds, which were large and unabraded, were dispersed throughout the fill of this feature. Sufficient of the vessel is present to determine its form and decorative scheme. These, together with the large, bucketlike proportions of the vessel, are distinctive of the Grooved Ware of the Durrington Walls style, which is the most widespread of the styles defined by Longworth (I97I).

The dating of Grooved Ware from Wales and elsewhere is hindered by the limited number of reliable absolute dates. Gibson considered that the largest known Grooved Ware group from Wales, that from Upper Ninepence, Powys, spanned the period $c$. 2900-2500 BC (Gibson I999, 44). This is at the earlier end of the range given by Garwood (c. 2900-2 I00 BC) for Durrington Walls and Clacton style Grooved Ware from southern England (Garwood I999). More recent studies of northern British material extends the earliest use of Grooved Ware vessels to c. 3 IOO BC and suggests 


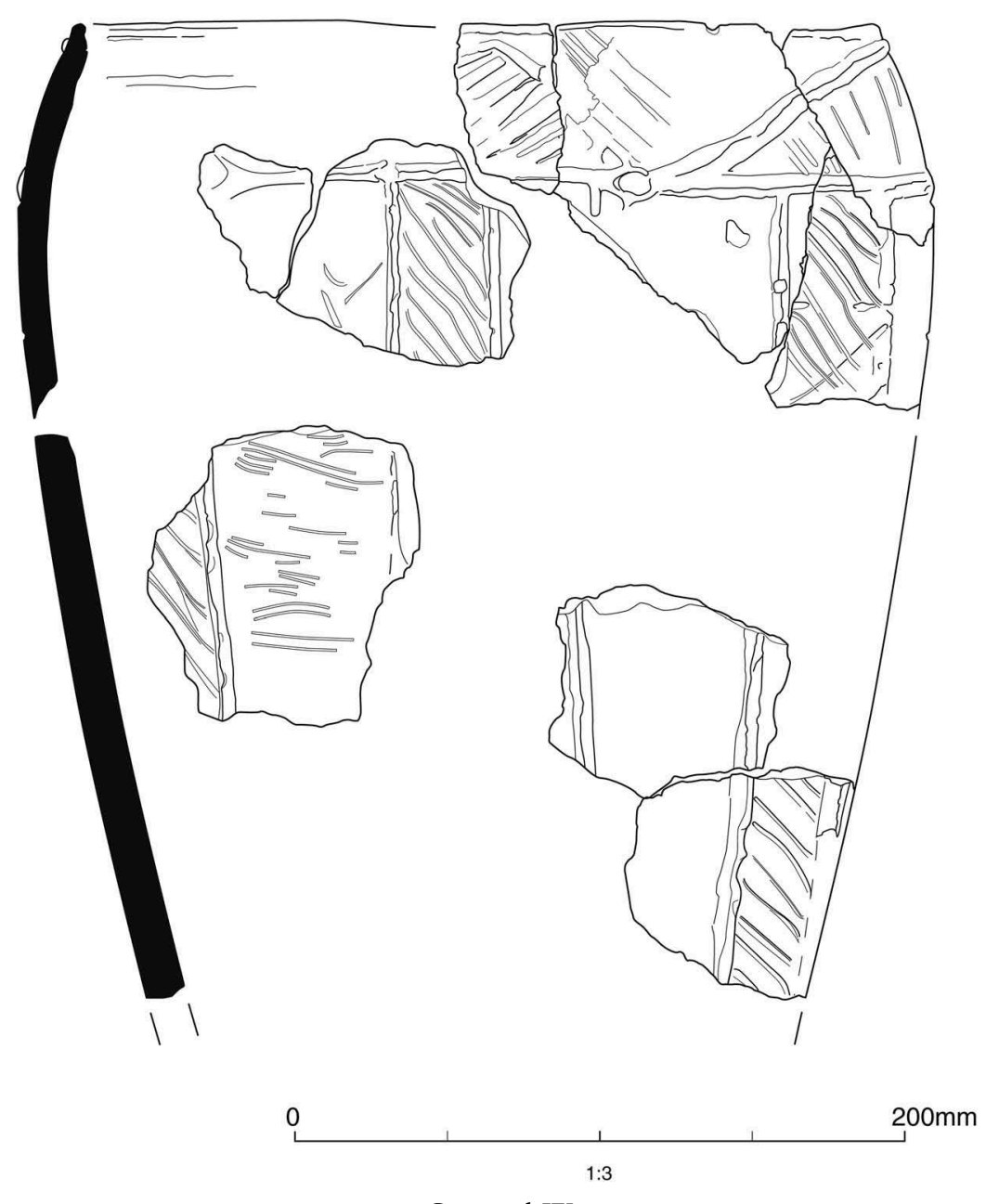

ILLUS. I5 Grooved Ware pottery

continuance to c. 2245 BC (Millson et al. 20I I). Needham considered that Grooved Ware might extend as late as his 'Fission Horizon', c. 2200 BC (Needham 2005).

Neolithic activity, including funerary activity, was attested from previous investigations from Four Crosses (Warrilow et al. I986, 8I-3). Pottery from the preceding excavations consisted of a round-bottomed deep bowl in the Mortlake style of the Peterborough Ware series. Radiocarbon determinations from deposits in association with the Mortlake bowl reflect the Middle Neolithic (later 4th millennium) focus for Peterborough Wares, and suggest that the Grooved Ware described here related to a separate and later phase of activity. A similar sequence of Middle Neolithic burial succeeded by a 'Grooved Ware settlement' was evidenced at Trelystan, I7 km to the south. There a minimum of nine vessels, also in the Durrington Walls style, were 
recovered in association with a sub-rectangular structure (Britnell I982). Locally, Grooved Ware is also known in the area of Welshpool, Powys (Gibson I994, I7I-5).

The size and form of Grooved Ware vessels would have made them suitable for storage or other utilitarian functions. The vessel from pit 2548 at Four Crosses, in common with vessels in the Trelystan group (Britnell I982, I63-4), exhibits evidence for its use as a cooking vessel as thick exterior sooting.

An unstratified sherd in grogged fabric ?EP GROG is suggested as dating between the Late Neolithic and earlier Bronze Age. This sherd is undecorated and identification is based on the fabric and characteristics of firing alone.

\section{Early Prehistoric Fabrics}

GW GROG

Grooved Ware fabric: patchy light brown/grey-brown surfaces with dark grey core. Medium-hard, smooth and with finely irregular fracture. Common self-coloured and well-sorted ( $\mathrm{I}-2 \mathrm{~mm}$ ) sub-rounded grog.

?EP GROG

Miscellaneous earlier prehistoric grog-tempered: buff-coloured exterior surface with grey core and interior. Soft with smooth feel irregular fracture. Common self-coloured and well-sorted $\left(0.5^{-} \mathrm{I} \mathrm{mm}\right)$ grog; sparse sub-rounded yellow-brown clay pellet ( $\mathrm{I}-$ $2 \mathrm{~mm}$ ); sparse sub-angular quartz (I $\mathrm{mm}$ ).

Illustration catalogue description (Illus. I5): Pit 2548. Grooved Ware vessel in Durrington Walls style. Rim is internally bevelled with double groove. The upper part (rim zone) is separated from the body by a horizontal raised cordon. Further, diagonal, cordons demarcate panels of incised in-fill. The body zone is divided by vertical cordons into panels of alternating broad and narrower width, filled with incised diagonal lines.

\section{ROMAN AND LATER}

Pottery of Roman date amounted to thirty sherds, weighing $496 \mathrm{~g}$. This small group was associated primarily with ditches forming the Romano-British field system. The majority was recovered by hand during the 2004-6 excavations, with additional small quantities (four sherds) recovered during the preceding evaluation (Marches Archaeology 2003) and identified by Jeremy Evans.

The condition of the Roman pottery is typically very poor. Surface deterioration is very marked for the majority of the Severn Valley-type wares, resulting in powdery surfaces. Most represented material occurs as small body sherds. A mean sherd weight, which at $\mathrm{I} 6.5 \mathrm{~g}$ is moderately high for a Roman assemblage, is skewed by the small size of the group and presence of a large rim sherd weighing $202 \mathrm{~g}$ from ditch fill 2052 from Enclosure I.

Almost all material is local in origin, comprising Severn Valley-type wares and related coarse oxidized wares (Table 2). Regional imports are restricted to single sherds in Malvernian-type rock-tempered ware, Oxfordshire whiteware mortaria and Dorset Black-Burnished ware (the latter noted only from the evaluation). The small size and 
TABLE 2 Roman pottery summary quantities by fabric

\begin{tabular}{|c|c|c|c|c|c|}
\hline FABRIC CODE & Description & Count & WeIGHT & VESSEL & RIM EVES \\
\hline LOC GREY & Misc. ?local greyware & I & I & I & - \\
\hline MALV RE A $†$ & Malvernian Group A reduced ware & 3 & I3 & I & - \\
\hline OXF WH† & Oxfordshire white ware mortaria & I & $2 \mathrm{I}$ & I & .04 \\
\hline LOC OX & Sandy oxidized ware & 7 & 87 & 4 & .04 \\
\hline SVW OX† & Severn Valley ware & I 8 & 374 & I4 & .27 \\
\hline Total & & 30 & 496 & $2 I$ & 0.35 \\
\hline
\end{tabular}

† indicates National Roman Fabric Reference Collection codes (Tomber and Dore I998)

restricted character of this group limits its worth for dating or as an indicator of site function and status. Two examples of a wide-mouthed jar (Webster's type C; I976, 25-7) in Severn Valley ware, and a flat-rim dish or bowl in coarser oxidized fabric were the only identifiable forms. The Roman group provides only broad dating, between the later first and fourth centuries AD. An unstratified and very abraded Oxford whiteware mortarium sherd probably dates to the third or fourth centuries AD. The Malvernian sherd, from fill 2063 from the curvilinear ditches, probably dates to the earlier Roman period. This small sherd is handmade and features burnished lattice decoration seen with Malvernian coarseware types and imitates Dorset Black-Burnished ware dishes and jars (Peacock 1967). The Dorset Black-Burnished ware noted from ditch E922 from the evaluation, very likely dates after $c$. AD I20.

\section{MEDIEVAL, POST-MEDIEVAL AND MODERN}

A total of IO2 sherds $(620 \mathrm{~g})$ recovered from the excavation and a further six sherds from the evaluation (examined by Stephanie Rátkai) span the fifteenth/sixteenth centuries to the nineteenth century; the majority date to the eighteenth and nineteenth centuries.

\section{FINGER RING}

$$
\text { by Ed MCSloy (Illus. i 6, I) }
$$

The copper-alloy ring was recovered from within grave 2596, internal to Barrow I5 . No bone survived from the grave, and from its position it is unclear whether this object was worn. X-ray fluorescence analysis was undertaken by David Dungworth to compare the metal composition against the regional signature based on detectable impurities. The full results of this analysis are contained within the archive.

The X-ray fluorescence analysis shows the metal composition to be leaded bronze, with impurities of arsenic, silver and a little antimony. Although lacking in detectable zinc, the other measurable impurities match the regional impurity signature for Iron Age artefacts, and point to a local origin.

A number of parallels can be cited for the ring, from Iron Age and into Early Roman contexts. Examples from western Britain include the large Middle and Late Iron Age group from Glastonbury Lake Village (Bulleid and Gray I9I 7, 209-10), and a single find from a 
1.
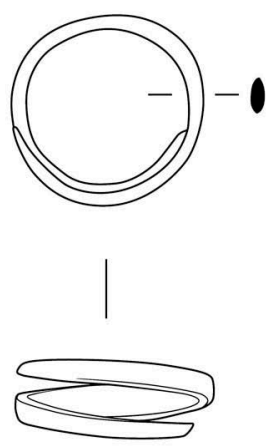

ILLUS. I 6
2.

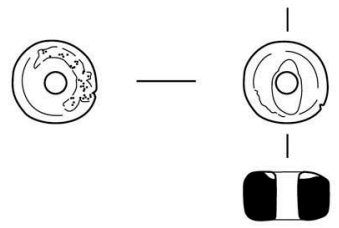

$50 \mathrm{~mm}$

Middle or Late Iron Age pit at Ryall, Quarry, Worcestershire (McSloy 2008, 57). There are few recorded instances of finger rings of this type from burials, more than likely due to the overall scarcity of Iron Age funerary deposits. One possible example is in association with a crouched burial, probably of Iron Age date, from Henbury, Bristol (McSloy 2006, 34).

There is some evidence for the re-emergence of coiled ring forms in the early AngloSaxon period (MacGregor and Bolick I993, I69-7I), although more commonly in silver. An Iron Age date in this instance is supported by the metal composition which matches the copper-smelting evidence from Four Crosses.

Catalogue description (Illus. I6, I): Grave 2596. Coil ring. Copper alloy. Complete coiled finger-ring from undecorated strip with tapering terminals. Single, partial coil (terminals overlap to a depth approximate to one third of the rings diameter). Internal diameter $\mathrm{I} 7 \mathrm{~mm}$. Width of strip $3.6 \mathrm{~mm}$.

\section{AMBER BEAD \\ by Ed. MCSloy (Illus. i 6, 2)}

The bead was retrieved during sorting of the coarse fraction of the processed soil sample taken from the fill of grave I327, and was the sole find from the deposit. As with most British amber, a source in the Baltic is likely. As an isolated find, it is difficult to date. It conforms to Beck and Shennan's Group I 'flat and thin disk beads', defined as having a diameter to thickness ratio between 2:Io and 5:Io of diameter (Beck and Shennan I99I, 53). The rounded profile characterizes it as of Class Ib (ibid.). Neither the broader or more tightly-defined classifications are chronologically diagnostic, the simple shape, not surprisingly re-occurring across the prehistoric period divisions. Incidence of Class I beads is highest by far in the Early Bronze Age however (ibid., 54, tables 4.3-4.4), with 27 of $4 \mathrm{I}$ dated occurrences from this period. This, together with the character and dating of the site, makes equivalent dating more likely, though far from certain.

Class I beads with Early Bronze Age associations are primarily distributed in southern England and mostly from funerary contexts. None of this date are known from Wales, with the closest cluster being the southern Pennines/Derbyshire (ibid., 72, fig. 6.I). 
Finds of prehistoric amber from Wales are, in general, rare (Beck and Shennan (I99I, I92-4) list nine find-spots). The sole Welsh occurrence of Class I beads, is as part of a necklace of Late Bronze Age date from Llangwyllog, Gwynedd (ibid., I93, fig. I I.23.2).

Catalogue description (Illus. I6, 2): Grave I 327 (fill I328). Amber bead. Clylindical/ disc-shaped with rounded rectangular section. Beck and Shennan Class Ib (Beck and Shennan I99I, 52-3, fig. 4.I). One face of this bead features an elongated depression it is unclear whether this is a vestige of the original amber piece or results from wear. Diameter $9 \mathrm{~mm}$; thickness $4.5 \mathrm{~mm}$; diameter of perforation $3 \mathrm{~mm}$.

\section{METALLURGY}

\section{by Tim Young}

A full report on the metallurgical analysis is available in the archive. This report represents a summary of the results. The site produced evidence for copper smelting during the Middle Iron Age (fourth-second centuries BC) from fifteen small cut features which occur in three groups, thirteen of which were probably furnaces. Two furnaces (2034 and 207I) form the north-west group, ten furnaces (2210, 2219, 2242, 2252, 2272, 228 I, 2290, 2297, 23 I 3 and 2373) make up the central group, together with an associated pit (2257); and a single furnace (I796) and associated pit (I766) comprise the south-east group. One furnace from the north-west group (2034) and one from the central group (2242) have fills which have both given calibrated radiocarbon dates from the fourth to second centuries BC (Table I).

The furnaces were heavily truncated and their original form uncertain, but they terminated in a basal pit of diameter $0.23 \mathrm{~m}$ to $0.36 \mathrm{~m}$ and, in at least one example (2242), were blown through a pre-fired ceramic block tuyère (Illus. I7). This tuyère had a rectangular lower part, $\mathrm{I} 20 \mathrm{~mm}$ wide, with a flat base. The top is not preserved within the main group of conjoining sherds, but further tuyère fragments suggest a curved upper section. It is not known how many tuyères might have been employed in each furnace. Despite the presence of oxidized-fired clays which appear to be associated with the fastening of the tuyères into the structure, there is little clear indication of how they were positioned or oriented, although the downward angle of the bore in the preserved specimen would be appropriate for a tuyère block mounted horizontally. The wedgeshaped profile of some oxidized clay fragments might indicate that the furnace profile widened above the tuyère.

Away from the tuyère the furnace lining was entirely reduced-fired. The lining was clearly a carefully placed layer covering the cut face of the gravelly substrate. In some examples this lining was of fine, dense clay, but in most examples it was very quartzrich, mostly of silt grade, but ranging up into medium sand. These silt-rich linings were highly vesicular (porous) from bloating, with vesicle size increasing towards the glassy surface of the lining. The gas forming the vesicles may have been from the use of either an organic-rich, or wet, lining material. Metal contamination of the lining was typically limited to a superficial layer I to $2 \mathrm{~mm}$ deep. Much of the vitrified furnace lining was fragmented and ex situ, suggesting that the lining may have been removed and crushed at the end of a smelt to extract any copper prills (solidified liquid globules) that may have sunk to the furnace floor. These features suggest that the lining was vitrified during 


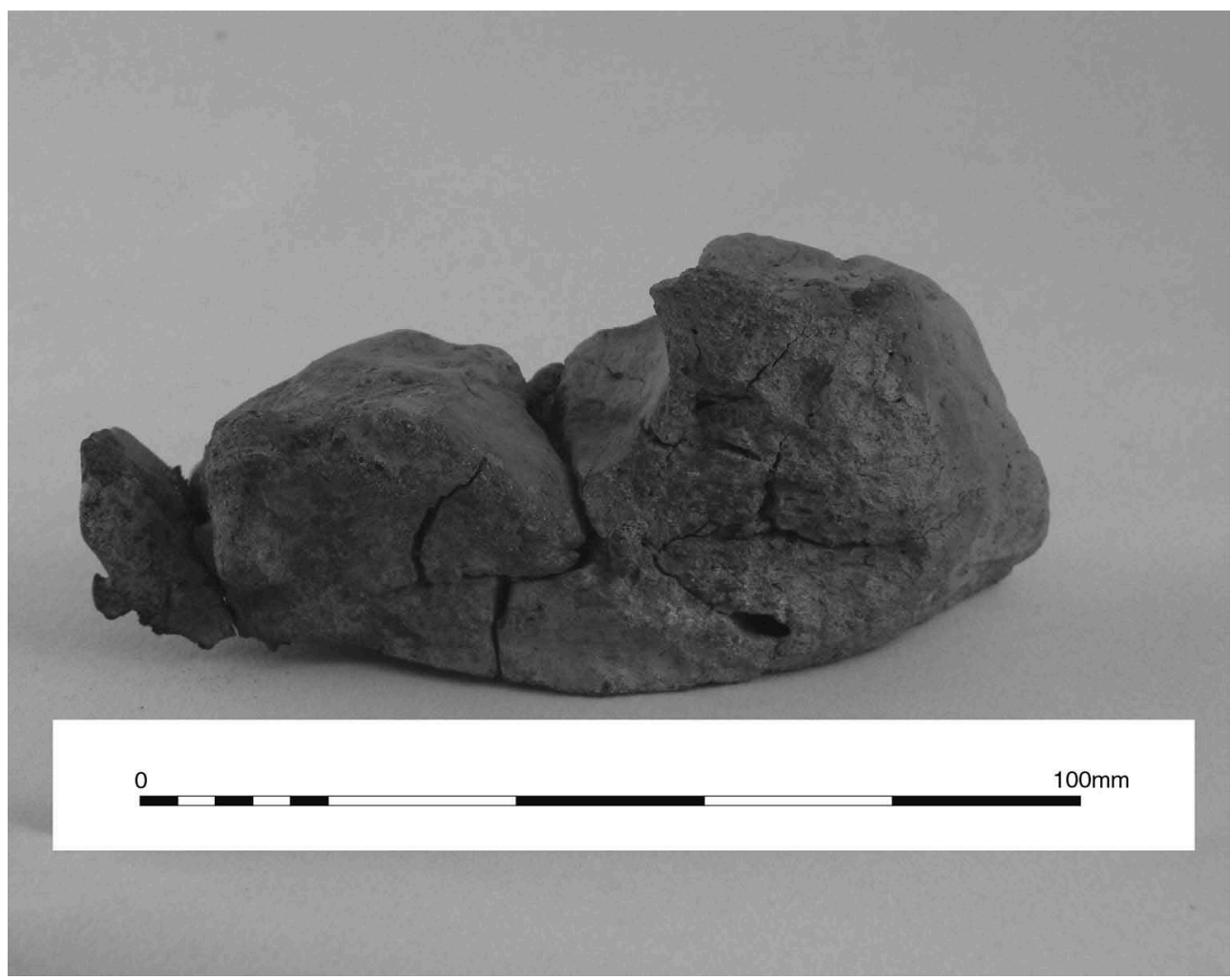

ILlus. I7 Block tuyére

a single use and the high vesicularity may have been deliberately induced in order to ease extraction of entrained copper prills. No fragments of fired clay showed an external surface, most graded into unfired clay or showed a contact with more gravelly material, suggesting that most, if not all, of the fired clay was from the lining of the pit, rather than from a superstructure.

The fills of the furnaces yielded a small quantity of ore, which indicates an oxidized zone source, with four main facies of ore material observed. The first facies comprises an iron oxide-rich (probably goethite) material with reticulate veining. Analysis indicates that this facies contains up to about 4 weight $\%$ of copper and zinc. A second ore facies is rich in copper, but low in zinc. The third and most abundant ore material was a facies that has a bulk composition with approximately 35 to 40 weight $\%$ copper and 5 to 8 weight $\%$ zinc. Local voids within this structure show late-stage iron oxide deposits with up to 5 weight $\%$ arsenic. The fourth ore facies was of botryoidal rosasite, with approximately 20 weight $\%$ copper and I 6 weight $\%$ zinc. The ore particles were all very small, with the largest approximately $8 \mathrm{~mm}$ across and many of sand grade. This material resembles what is known of the supergene mineralization on Llanymynech Hill, $3 \mathrm{~km}$ north-west of the site (Musson and Northover I989). 
Metallic copper occurred as small prills (small droplets and runs) (up to about $5 \mathrm{~g}$ ) as well as microscopic inclusions in the slag and furnace lining. The small number of copper prills have a variable composition with up to 0.6 weight $\%$ zinc and numerous other impurities, but smaller blebs trapped in slag show an even wider range of compositions, with up to 5.7 weight $\%$ iron, $2.0 \%$ nickel, I. $8 \%$ zinc, $5.4 \%$ arsenic, $0.8 \%$ silver, $0.4 \%$ antimony and $\mathrm{I} 4.4 \%$ lead. Although the variation shown by individual blebs would be homogenized during the smelting process, there may still have been significant variability in the product, depending on the balance of the ore types in any particular smelt.

Slag was only recovered in small quantities, with the total weight of copper and slag prills and blebs recovered from the fifteen features being approximately $880 \mathrm{~g}$ (compared with $6853 \mathrm{~g}$ of furnace lining). The slag included some rare examples of prilly flow slag, solidified during its descent through the furnace charge. The flow slag is zincrich, but relatively copper-poor. Slag was also recovered from sieved samples as sandgrade crushed grains. The fragmented slags include some particles of similar mineralogy to the intact flow slags, but most are dominantly glass. These glassy slags may have formed on the furnace walls. One fragment was a sinter of ore fragments, quartz-rich sediment and charcoal fragments, bound by a slag rich in zincian wustite, and probably represents a variety of materials which have accumulated on the furnace floor.

The presence of the sintered material, together with the slag and copper prills, indicates that the material being smelted was not contained within a crucible, but the reaction was taking place within the furnace, a practice that is normal for the period.

Spherical, microscopic magnetic slag particles resembling spheroidal hammerscale were recovered from several of the furnaces. The presence of hammer-scale-like particles was noted from a variety of contexts, from Bronze Age to Roman in date. It is likely that many, if not all, of these occurrences were actually of microscopic residues from copper smelting. Such material may be intrusive in earlier contexts, while its occurrence in features of Roman date close to the Iron Age copper smelting furnaces may be due to residual material. There is no convincing, independent, evidence for iron-working on the site.

The copper prills have slightly lower zinc contents than other examples of Iron Age high-zinc copper, attributed to production in northern Powys (and probably specifically the Llanymynech) area. In other respects the metal shows many similarities, with elevated contents of the same set of impurity elements. In particular, the relatively high levels of iron, arsenic and silver bear close comparison, and the levels of lead are even higher than those previously reported.

The high zinc content of northern Powys bronzes and raw copper pieces (Musson et al. I992; Musson and Northover I989; Northover I99I) has created much discussion. Northover (I99 I and in Musson and Northover 1989) suggested that the high zinc content of some bronze from Iron Age contexts in Wales (up to I.25\%) was due to the use of a high-zinc copper source, although he could not exclude some of the evidence from Llanymynech and elsewhere as indicating the use of brass. The present study presents compelling evidence for the use of a high-zinc ore, but relatively modest levels of zinc were present in most copper samples. The zinc contents of the slag and furnace lining were, in contrast, very high. This suggests that much of the zinc may have been 
lost as vapour during smelting, so that little entered the copper metal, although much was trapped by the liquid slags. It is quite possible that variation in the zinc content of the copper smelted from these zinc-rich ores could be produced by different smelting techniques, with the open-furnace smelting at Four Crosses trapping relatively little of the zinc in the copper, whereas smelting in a closed crucible might increase the proportion incorporated into the metal.

Northover also drew attention to the use of leaded bronze in the same area, despite this being an alloy which elsewhere had passed out of use by the end of the Bronze Age, before being used again from the first century AD (Northover I99I, table 25). The present material shows a range of lead contents, with significant elevation above normal levels for a raw copper. The copper analyses from this study show an average of $2.2 \%$ lead, with one droplet as high as $14.4 \%$ lead (Table 3 ). This suggests that the material described in Northover's regional review may not only have a naturally high zinc content, but may similarly have a naturally high lead content, rather than being an exceptional use of lead as a deliberate alloy in bronze in Wales at this period.

A single artefact from the Four Crosses site, a finger ring, shows on qualitative analysis to be a leaded bronze, with impurities of arsenic, silver and a little antimony. This artefact is probably to be added with the list of objects with the regional impurity signature, although it did not have detectable zinc. Indeed, so far as may be determined from the analysis, it matches the observed copper composition produced at Four Crosses and may have been produced from copper smelted at this site.

The small size of the recovered ore particles prevents interpretation of the ore as mined; it is unclear to what extent the different ore facies may have been intimately mixed within the deposits and to what degree, therefore, the bulk ore would have been homogeneous in composition between batches. The variability in the

TABLE 3 Metallurgical analysis

Comparison of bulk EDS analyses of copper from the present study (in wt $\%$ element) with microprobe data from other finds of raw copper in the area (comparative data adapted from Northover I991, table 2 - his data for cobalt, gold and bismuth are omitted because they were at levels below detection for the EDS system used in the current study). $\leq$ below detection.

\begin{tabular}{|c|c|c|c|c|c|c|c|c|}
\hline SAMPLE & $\#$ & FE & $\mathrm{NI}_{\mathrm{I}}$ & $Z_{N}$ & As & $\mathrm{AG}_{\mathrm{G}}$ & $\mathrm{SB}_{\mathrm{B}}$ & $\mathrm{PB}$ \\
\hline \multirow[t]{2}{*}{ LBDi: Llwyn Bryn-dinas } & I & 0.80 & 0.09 & 3.76 & 0.40 & O.I 6 & O.I 4 & 0.23 \\
\hline & 2 & 0.79 & O. I I & $3 \cdot 37$ & 0.38 & O.I I & 0.07 & 0.06 \\
\hline \multirow[t]{4}{*}{ LI: Llanymynech hillfort } & I & 0.04 & O.I I & I.02 & $<$ & 0.42 & 0.06 & 0.25 \\
\hline & 2 & 0.05 & 0.08 & I.4I & 0.88 & 0.97 & 0.09 & I.O4 \\
\hline & 3 & 0.05 & 0.06 & I.03 & O.I I & 0.22 & $\operatorname{tr}$ & I.OO \\
\hline & 4 & $<$ & 0.07 & O. I I & 0.64 & 0.43 & 0.03 & $0.4 \mathrm{I}$ \\
\hline \multicolumn{9}{|l|}{ Four Crosses - this study } \\
\hline Mean value (large prills) & & 0.08 & O. I I & O.I I & 0.97 & O.I 6 & $<$ & 2.23 \\
\hline Mean value (all) & & $\mathrm{I} .23$ & 0.34 & $0.2 \mathrm{I}$ & I.I7 & O.IO & $<$ & 2.28 \\
\hline Maximum value (all) & & 3.38 & 2.02 & 0.90 & 4.29 & 0.44 & $<$ & I 4.37 \\
\hline
\end{tabular}


composition of the different facies of ore recovered from the site, however, makes it possible that batches of ore might have had quite widely different compositions, particularly in terms of the copper to zinc ratio and in the content of the ferruginous material, which may have contained much of the arsenic too. This leaves open the question of the homogeneity of composition of the copper produced. The microscopic droplets observed in the present material were of widely-varying composition, but may have become homogenized during the smelting process and the accumulation of small droplets and prills into the bulk product.

In contrast to previous interpretations of the zinc-rich copper from the Welsh Iron Age, it is clear that the ore smelted at Four Crosses was not dominantly sulphidic but was from the oxidic zone (contra Musson and Northover I989, 279 and Northover I99I, 2I4). The new evidence allows the furnace ('bowl hearth 2I') identified by Musson and Northover (1989) at Llanymynech Hillfort to be reinterpreted as a similar structure to the furnaces at Four Crosses. The pit of this furnace was of similar size to the Four Crosses furnaces (approximately $0.40 \mathrm{~m}$ diameter, $0.25 \mathrm{~m}$ diameter at the base and $0.25 \mathrm{~m}$ deep), and was of a broadly similar Iron Age date (cal. 336 BC-AD I 29 for the furnace and cal. $386 \mathrm{BC}-62 \mathrm{BC}$ for an associated pit).

\section{THE HUMAN REMAINS}

\section{by Harriet Jacklin (with preliminary analysis by Teresa Gilmore)}

Six inhumations (Skeletons I/2,3-7) and four deposits of cremated bone (Cremations I-4) were recovered (Tables 4 and 5).

The analysis of the inhumations and the cremations included assessment of age, sex, dentition, dental health, cranial and post-cranial metrics, non-metric traits and stature of all the skeletal material whenever possible. Pathological analysis was also undertaken. The results were recorded using a standardized recording form created by Jacklin (2005), in line with Brickley and McKinley (2004). References used during skeletal analysis include Bass (I995), Buikstra and Ubelaker (I994), Brothwell (I98I) and McKinley and Roberts (I993). All fusion data within this report are based on Scheuer and Black (2000). References used during cremation analysis include: McKinley (I994), McKinley (2000a), McKinley (200ob), and McKinley and Bond (200I). Pathological literature consulted during analysis includes Aufderheide and Rodriguez-Martin (2003), Ortner (2003) and Roberts and Waldron (I995).

\section{INHUMATIONS（TABLE 4)}

All six inhumations were very poorly preserved and were very incomplete. The poor preservation was mainly due to the acid nature of the soil. Completeness is determined on a percentage basis depending on the amount of the skeleton present for analysis. Skeletons I/ 2 and 5 were the best preserved and both had between $5 \%$ and $10 \%$ of the skeleton present; these are detailed below. The remaining individuals (Skeletons 3, 4, 6 and 7) were the least well preserved and had around $5 \%$ of their skeleton present, and these are not discussed further. 
FOUR CROSSES, LLANDYSILIO

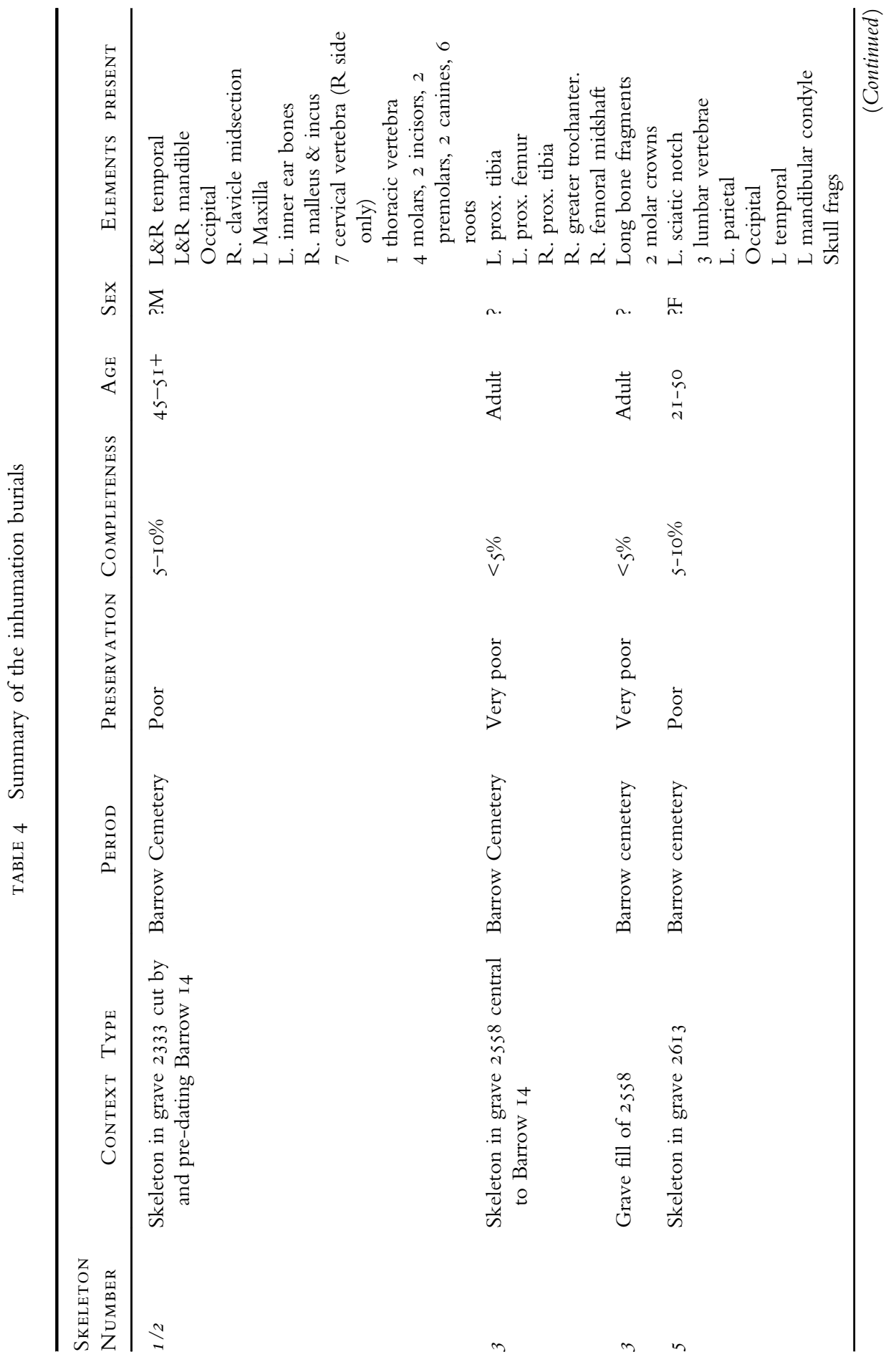




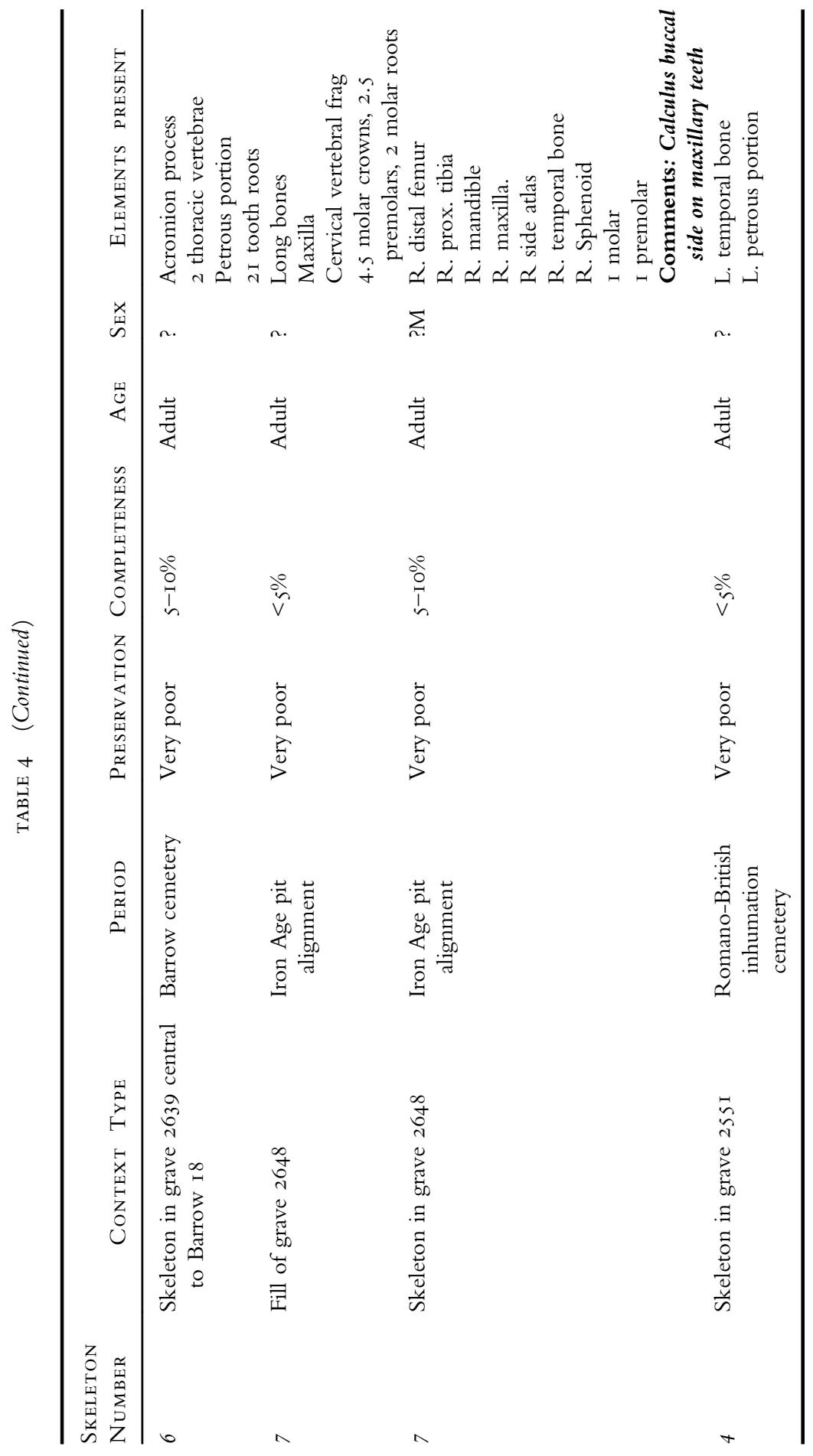


FOUR CROSSES, LLANDYSILIO

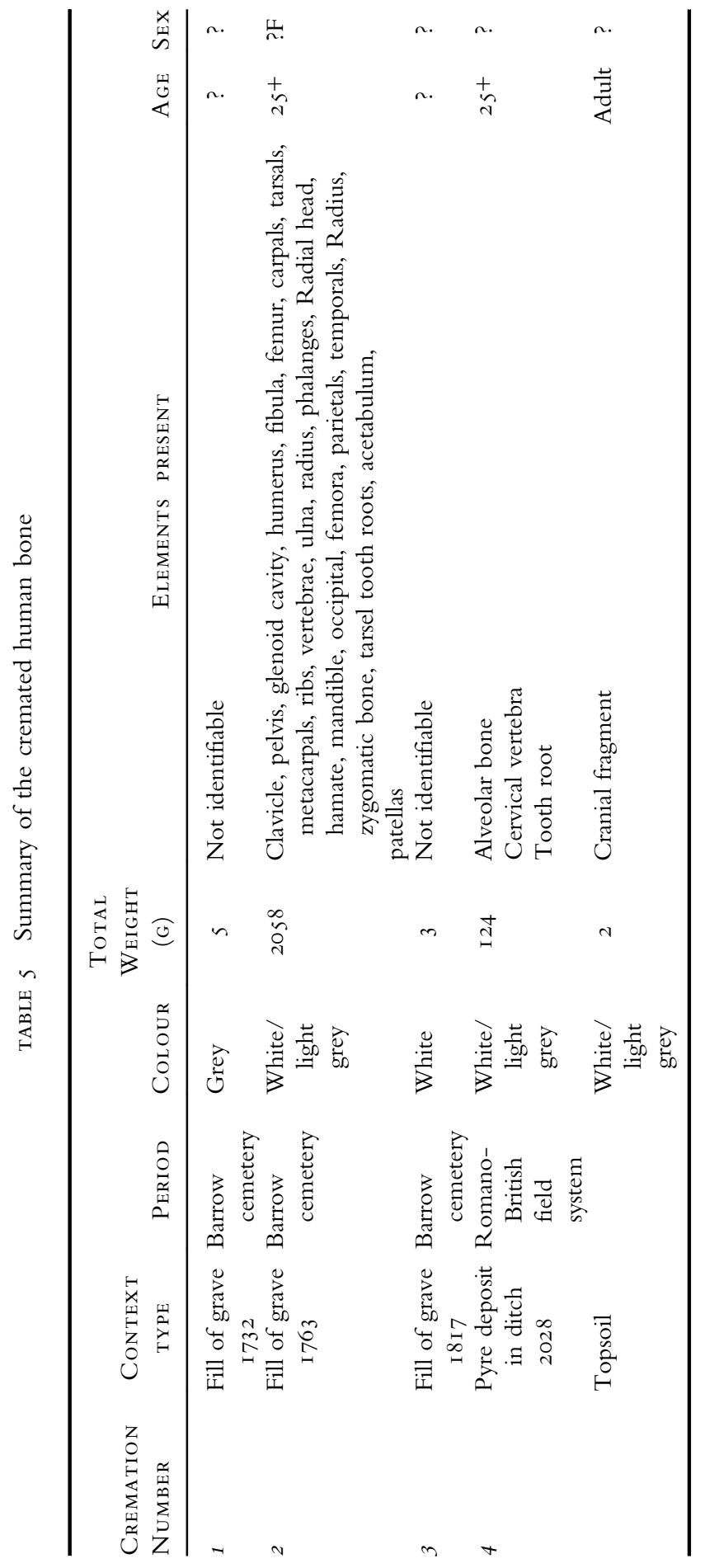




\section{Skeleton $1 / 2$}

Skeleton I/2 was orientated north-west to south-east (head to foot) and was almost completely truncated by the ring ditch of Barrow I4. The grave cut 2333 was oval in shape, possibly indicating that this was a crouched/semi-crouched burial. The bone preservation was classed as fair but fragmented, and due to truncation, less than I $5 \%$ of the skeleton was available for analysis. No associated finds were recorded with the individual.

The skeleton was sexed as a 'possible male' based on the assessment of the cranium (nuchal crest, left and right mastoid process) and the mandible (mental eminence). The overall size of the individual and the robusticity of the remains were also taken into account. A definite sex estimation could not be made due to the lack of more reliable sexual indicators such as the os coxae. The age at death of the individual was estimated to be between 45 to $5 \mathrm{I}+$ years based on dental eruption, dental attrition and epiphyseal fusion. Ante-mortem tooth loss, alveolar bone re-absorbsion, cranial suture closure and age-related changes such as osteoarthritis were also taken into account. Stature could not be established due to the lack of complete long bones.

The upper vertebrae were affected by localized osteoarthritis and ankylosis, possibly initiated by trauma. The cervical vertebrae $\left(\mathrm{C}_{2}\right.$ and $\left.\mathrm{C}_{3}\right)$ were completely fused at the body and right articular facets (the left was not present). Osteoarthritis affected the bodies of the cervical $\left(\mathrm{C}_{2}-7\right)$ and the thoracic (TI) vertebrae. Osteoarthritis is common in both ancient and modern populations; it is primarily an age-related disorder but can also be triggered by traumatic injuries (Rogers and Waldron I995). No other pathological or metabolic evidence of ill-health or disease was found. The dentition comprised of nine dental roots from both the maxilla and mandible. One carie was found affecting the occlusal surface of the lower right molar.

\section{Skeleton 5}

Skeleton 5 (grave 26I3) was orientated south-west-north-east (head to foot), buried in a supine extended position and located immediately outside Barrow 20. Bone preservation was poor, and due to truncation, less than $25 \%$ of the skeleton was available for analysis. The skeleton was categorized as a 'possible female' based on the assessment of the cranium (nuchal crest, left and right mastoid process) and fragments of the pelvis (left sciatic notch). The overall size of the individual and the robusticity of the remains were also taken into account. Due to a lack of age indicators, only a broad age estimate could be given of between 2 I to 50 years. This was based on the assessment of cranial suture fusion and whether any age-related changes were visible. Stature could not be established due to the lack of complete long bones. No pathological or metabolic evidence of ill-health or disease was found affecting the individual.

\section{CREMATIONS (TABLE 5 )}

Overall the preservation of the cremation burials was significantly better than the preservation of the inhumed burials. Cremation 2 was the best preserved with over two kilograms of cremated bone surviving. Cremations I and 3 were the least well- 
preserved with less than Io g of cremated bone surviving and are not discussed further. The pyre debris of Cremation 4 consisted of over Ioo g of material present.

An adult age could be assigned to all four cremation burials, but due to the degree of fragmentation and lack of suitable parts present (i.e. pubic symphysis, auricular surface and dental attrition) an exact age could not be determined for Cremations I and 3 . Cremation 2 was the only burial sufficiently well-preserved to attempt to diagnose sex. Only the analysis of the two largest surviving assemblages from Cremations 2 and 4 is described in detail here.

\section{Cremation 2}

Cremation 2 was dated to the Bronze Age through radiocarbon dating, and nearby Cremation $\mathrm{I}$ is assumed to be contemporary. The cremated remains weighed $\mathrm{I} 778 \mathrm{~g}$ and there was no duplication of skeletal parts. The surviving cremated bone represents a 'possible female' aged $25^{+}$years old. The age at death was based on the assessment of epiphyseal fusion and the estimation of sex based on assessment of the cranial fragments, the mandible, femoral measurements, and overall size and robusticity. The majority of the identifiable skeletal elements represented within the cremation were the long bones and the cranium, which take longer to burn than other skeletal elements. The small quantity of the smaller skeletal elements such as the hands, feet and ribs is as expected, as these elements take a shorter time to reduce effectively. The colour of the cremated remains reflects the degree of oxidization (temperature) to which the bone was submitted. The majority of the cremated material within Cremation 2 assemblage reached a temperature of $>c$. $600 \mathrm{deg}$. C (full oxidization).

\section{Cremation 4}

The cremated material was recovered from a ditch and is believed to represent pyre debris. The material was not urned and no cut was found in association with the cremated remains. The bone weighed 24I g and there was no duplication of skeletal parts. The bones seem to represent an adult aged $25^{+}$years based on epiphyseal fusion. No sex indicators were available for study and no pathology was visible.

\section{PLANT MACROFOSSIL REMAINS}

\section{by Elizabeth Pearson}

A total of 223 bulk samples was taken for the recovery of environmental remains, and the assemblage was assessed. Samples were selected for full analysis from deposits associated with the round barrow cemetery, Iron Age copper working activity, and Roman cremation deposits. The samples were processed by flotation. The flots were collected on a $250 \mu \mathrm{m}$ sieve and the residue retained on either a I mm or $500 \mu \mathrm{m}$ mesh. This allowed for the recovery of items such as small animal bones, molluscs and seeds. The residues were fully sorted and the flots were scanned using a low power MEIJI stereo light microscope. The plant remains were identified using modern reference collections maintained by Worcestershire County Council, and a seed identification manual (Cappers et al. 2006). Nomenclature for the plant remains follows Stace 200 I. 
Environmental remains were generally sparsely distributed across the site. These included charred plant remains, unidentifiable bone fragments, and uncharred seed and insect remains. The uncharred seeds and insect remains are unlikely to have survived in the soil for long, as there was no evidence of waterlogging or anoxic (oxygen reduced) conditions on the site. Moreover, a similar range of uncharred plant remains are found in all phases, suggesting they are modern and intrusive. The charred plant remains recovered are detailed in Tables 6 and 7 .

Environmental remains from the ring ditches of the barrow cemetery were too sparse to determine any significant difference between the sampled ring ditches (Table 6). Only occasional charred grains of emmer or spelt wheat, unidentified grass grains (Poaceae sp indeterminate), fragments of hazelnut shell and a lime fruit

TABLE 6 Charred plant remains from the round barrow cemetery ring-ditches

\begin{tabular}{|c|c|c|c|c|c|c|c|}
\hline \multirow{2}{*}{ Latin name } & \multirow[b]{2}{*}{$\begin{array}{c}\text { Common } \\
\text { name }\end{array}$} & \multirow[b]{2}{*}{ Habitat } & \multicolumn{2}{|c|}{$\begin{array}{l}\text { BARROW } \\
\text { I I }\end{array}$} & \multirow{2}{*}{$\begin{array}{c}\text { BARROW } \\
\text { IO } \\
\text { I4I5 }\end{array}$} & \multicolumn{2}{|c|}{$\begin{array}{l}\text { BARROW } \\
\quad \text { I } 2\end{array}$} \\
\hline & & & I 355 & I367 & & I 476 & I 487 \\
\hline $\begin{array}{l}\text { Triticum dicoccum/spelta grain } \\
\text { Cereal sp. indet grain (fragment) } \\
\text { Poaceae sp indet grain } \\
\text { Poaceae sp indet grain (small) } \\
\text { Corylus avellana shell fragment } \\
\text { cf. Tilia sp fruit } \\
\text { unidentified seed } \\
\text { unidentified root fragments } \\
\text { unidentified cereal grain/seed } \\
\text { fragment }\end{array}$ & $\begin{array}{l}\text { emmer/spelt wheat } \\
\text { cereal } \\
\text { grass } \\
\text { grass } \\
\text { hazelnut } \\
\text { lime }\end{array}$ & $\begin{array}{c}\text { F } \\
\text { F } \\
\text { AF } \\
\text { AF } \\
\text { C } \\
\text { C }\end{array}$ & I & 2 & $\begin{array}{l}\mathrm{I} \\
2\end{array}$ & I & I \\
\hline & & & & & Barrow 9 & & \\
\hline Latin name & $\begin{array}{c}\text { Common } \\
\text { name }\end{array}$ & Habitat & I 565 & I 57 I & I 593 & I 599 & 1625 \\
\hline Triticum dicoccum/spelta grain & $\begin{array}{l}\text { emmer/spelt } \\
\text { wheat }\end{array}$ & $\mathrm{F}$ & & & & & \\
\hline Cereal sp. indet grain (fragment) & cereal & $\mathrm{F}$ & & & + & & \\
\hline Poaceae sp. indet grain & grass & $\mathrm{AF}$ & & & I & & \\
\hline Poaceae sp. indet grain (small) & grass & $\mathrm{AF}$ & & I & & & \\
\hline Corylus avellana shell fragment & hazelnut & $\mathrm{C}$ & & & 4 & & 2 \\
\hline $\begin{array}{l}\text { cf. Tilia sp. fruit } \\
\text { unidentified seed }\end{array}$ & lime & $\mathrm{C}$ & & & & I & \\
\hline unidentified root fragments & & & & 2 & & & \\
\hline $\begin{array}{l}\text { unidentified cereal grain/seed } \\
\text { fragment }\end{array}$ & & & I & & & & \\
\hline
\end{tabular}

$\mathrm{A}=$ cultivated ground, $\mathrm{B}=$ disturbed ground, $\mathrm{C}=$ woodlands/hedgerows/scrub etc., $\mathrm{D}=$ grasslands, meadows and heathlands and $\mathrm{F}=$ cultivar 
TABLE 7 Charred plant remains from Iron Age and Romano-British contexts

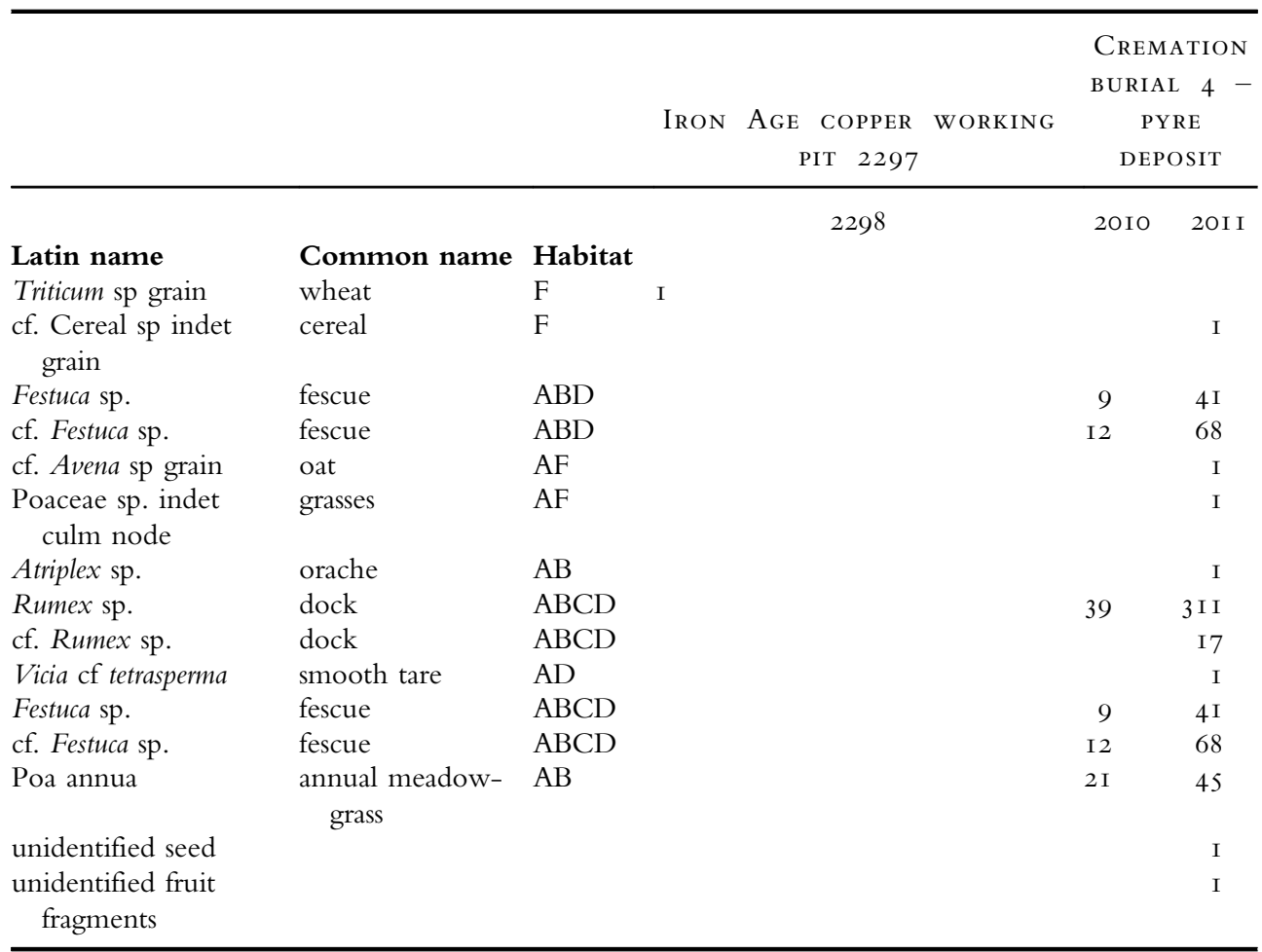

$\mathrm{A}=$ cultivated ground, $\mathrm{B}=$ disturbed ground, $\mathrm{C}=$ woodlands/hedgerows/scrub etc., $\mathrm{D}=$ grasslands, meadows and heathlands and $\mathrm{F}=$ cultivar

were recorded. Free-threshing wheat was identified in the ring ditch of Barrow I2, which is uncommon in deposits of this period compared to emmer and spelt wheat, but as it is in an upper fill, may be instrusive. Spelt wheat appears to have been the main wheat crops in cultivation at this time. Occasional weed seeds were noted during assessment (Pearson 2006), which were presumably harvested and charred with the crop.

From 2298, fill of copper-working pit 2297, only one cereal grain of an unidentified wheat species was recovered (Table 7).

Samples from the Romano-British field system were generally more charcoal-rich than the earlier samples, although identifiable remains were only occasionally present. Two deposits 2010 and 20 I f from Cremation 4, tipped into the north-eastern ditch of Enclosure I, were relatively rich in identifiable charred remains (Table 7). They were dominated by charred nutlets of dock, and small grass grains which included fescue grass and annual meadow grass. 
The low level of charred cereal crop remains is not unexpected from a barrow cemetery context. Sparse remains are consistent with other ceremonial sites in the British Isles, with low levels of waste being expected, as agricultural processing is more likely to have taken place close to settlement areas. However, any scant remains recorded may represent the remains of food gifts associated with burials (van der Veen I985). Charred plant remains were similarly sparse in a Beaker pit associated with the barrow complex at Four Crosses, excavated during I98 I-85 (Milles I986), and in two Bronze Age round barrows at Pant y Butler, Llangoedmor, Ceredigion (Caseldine and Griffiths 2OI3), although here hazelnut fragments were relatively more common.

At Four Crosses, emmer or spelt wheat are likely to have been the main wheat crops in cultivation, evidence of which was present in these samples. Hazelnut fragments are frequently found in deposits of this date and were probably commonly collected as part of the staple food resource. The lime fruit may derive from timber and branches burnt on fires during ceremonial (or other) activities.

Pollen evidence from Four Crosses indicates a relatively open, grassland-dominated landscape surrounding the barrow (see Head below) with no specific evidence of cereal cultivation. In Wales generally, pollen evidence shows an increase in woodland clearance only from the later Bronze Age onwards, with indications of a predominantly pastoral economy but some cultivation of cereals (Caseldine 2004). The low levels of cereal remains at Four Crosses may reflect low levels of cereal cultivation in the area, but, as is the case through much of Wales and western England, there are few comparative assemblages from both ceremonial and non-ceremonial sites on which to base a broad interpretation.

The low level of charred cereal crop waste associated with the Romano-British field system, suggests that processing of cereal crops was only undertaken on a small-scale in this area. The abundant dock nutlets and small grass grains from the cremation deposits suggest that the pyre was made on grassy or abandoned arable land, or that grassy or fast-burning material was used as tinder. Docks and grasses when dry make particularly good tinder material, so are likely components for a pyre. Similar assemblages have been recovered from other pyre deposits, such as those of Late Iron Age date found at Walton, Warwickshire (Pearson 20I2); Harbury, Warwickshire (Monckton 2009) and of Bronze Age date from Barton-under-Needwood, Staffordshire (Pearson 200I; Martin I996).

\section{CHARCOAL}

\section{by ROWENA GALE}

Eight samples of charcoal were selected for full analysis from Bronze Age cremation burials, Romano-British cremation debris, and deposits of probable industrial fuel from Iron Age copper-working. Species identification was undertaken to evaluate and compare the fuel employed for cremation and industrial activities, and also to obtain environmental data. 
TABLE 8 Charcoal identification

\begin{tabular}{|c|c|c|c|c|c|c|c|}
\hline SAMPLE & Context & DESCRIPTION & Alnus & Corylus & Prunus & Quercus & Sambuc. \\
\hline \multicolumn{8}{|c|}{ Round Barrow Cemetery } \\
\hline 56 & I 733 & $\begin{array}{l}\text { Cremation I } \\
\text { Primary fill I }\end{array}$ & - & 7 & - & $2 \mathrm{Ih}, 54 \mathrm{~s}$ & - \\
\hline 70 & $\begin{array}{l}\mathrm{I} 775 / \\
\mathrm{I} 776\end{array}$ & $\begin{array}{l}\text { Cremation } 2 \\
\text { Final fill }\end{array}$ & - & 7 & - & Ih, I5s & - \\
\hline 7I & $\begin{array}{l}\mathrm{I} 777 / \\
\mathrm{I} 778\end{array}$ & $\begin{array}{l}\text { Cremation } 2 \\
\text { Primary fill }\end{array}$ & - & 7 & - & $4 \mathrm{Oh}, \mathrm{I} 3 \mathrm{~s}$ & - \\
\hline \multicolumn{8}{|c|}{ Iron Age Copper Working Pits } \\
\hline I 27 & 2243 & Primary fill & 8 & I & 2 & $39 \mathrm{~h} / \mathrm{u}$ & - \\
\hline I 28 & 2245 & of pit 2242 & 3 & I & 3 & $28 \mathrm{~h}$ & - \\
\hline $\mathrm{I} 4 \mathrm{O}$ & 23 I 4 & $\begin{array}{l}\text { Primary fill } \\
\text { of pit } 23 \mathrm{I} 3\end{array}$ & - & - & - & $78 \mathrm{~h}$ & - \\
\hline \multicolumn{8}{|c|}{ Romano-British } \\
\hline IO3 & 2010 & Cremation burial 4. & 3 & - & - & - & I \\
\hline IO4 & $20 \mathrm{II}$ & $\begin{array}{l}\text { Pyre deposit } \\
\text { in ditch } 2028\end{array}$ & I 8 & I & - & - & 3 \\
\hline
\end{tabular}

Key: $\mathrm{h}=$ heartwood; $\mathrm{s}=$ sapwood (diameter unknown); $\mathrm{u}=$ maturity undetermined (Quercus only) The number of fragments identified is indicated

The condition of the charcoal varied from firm to friable. The charcoal was too fragmented to include intact sections of roundwood. The samples were prepared using standard methods (Gale and Cutler 2000). Anatomical structures were examined using incident light on a Nikon Labophot-2 compound microscope at magnifications up to $\mathrm{x} 400$ and matched to prepared reference slides of modern wood. When possible, the maturity of the wood was assessed.

The taxa identified are presented in Table 8. Classification follows that of Flora Europaea (Tutind et al. I964, 80). When a genus is represented by a single species in the British flora it is named as the most likely origin of the wood, given the provenance and period, but it should be noted that it is rarely possible to name individual species from charcoal fragments, and exotic species of trees and shrubs were introduced to Britain from an early period (Godwin I956; Mitchell 1974). The anatomical structure of the charcoal was consistent with the following taxa:

- Betulaceae. Alnus glutinosa (L.) Gaertner, European alder;

- Caprifoliaceae. Sambucus nigra L., elder;

- Corylaceae. Corylus avellana L., hazel;

- Fagaceae. Quercus sp., oak;

- Rosaceae. Prunus spinosa L., blackthorn. 
THE BARROW CEMETERY AND BURIALS

\section{Cremation 1}

Sample 56 from the primary fill (I733) of Cremation I consisted mostly of fast-grown oak, comprising heartwood and sapwood, with a small amount of hazel.

\section{Cremation 2}

In this cremation the bone had been placed in the base of the cut, which was then backfilled. It is probable that the cremation took place close by. Charcoal samples 70 , the upper fill (I775/I776), and 7I, the primary fill (I777/I778), of Cremation 2 were similar in species content to Cremation I.

\section{IRON AGE COPPER WORKING}

A large volume of charcoal, sample I4O, was recovered from the primary fill (23 I4) of pit 23 I 3 and was named as oak heartwood. If, as seems likely, this material resulted from metal working, the evidence implies the specific selection of oak; had the material been back-fill, a diverse range of species would be anticipated.

A further five pits in this central group which contained copper-working debris (slag and fired clay) were sampled. Charcoal from associated samples I 27 and I 28 from 2243, the primary fill of pit 2242 , almost certainly represents fuel waste from the copper industry. Although fuel debris deposited here consisted predominantly of oak heartwood, other species included alder, hazel and blackthorn.

ROMANO-BRITISH FIELD SYSTEM

\section{Cremation 4}

The remains of this cremation appear to have been deposited directly into the ditch of Enclosure I. Although burnt bone was plentiful only a small amount of the charcoal collected was suitable for identification. Samples IO3 (20IO) and IO4 (20II) included alder, hazel and elder.

\section{IS C USSION}

The methods of pyre construction at Four Crosses are unknown; evidence from Cremations I and 2 suggests that the pyres were built predominantly from oak largewood. Hazel, also present in both contexts, may have been incorporated into the main framework or as kindling. In Cremation 2, the cremated bone (and charcoal) was placed in the base of the pit and it is probable that the pyre site was nearby. The close proximity of the two cremation burials and the similarity of the charcoal residues infer common cremation practices during the Bronze Age. Oak heartwood would have provided a high calorie, long-lasting heat source. In addition to the practical aspects of wood/fuel supply and associated burning qualities, it is possible that for ritual/ ceremonial use such as cremations, certain tree species were considered as more auspicious or important. There is some evidence from the Bronze Age, for example, to link single species pyre construction (particularly oak, which was especially venerated 
in the prehistoric period) with high status cremations (Smith 2002; Mullin 2003), and Tacitus (Ger. 2. 7), writing in the first century AD, referred to the Gaulish use of particular (unspecified) woods for high-status pyres.

The Romano-British cremation, on the other hand, appears to differ significantly from those of the barrow cemetery. The taxa identified consisted of shrubby species (alder, hazel and elder), with no evidence of the use of oak, although with only a small sample available the use of oak cannot be ruled out. The apparently casual deposition of the cremated bone and possible lack of substantial timber/ritual species for pyre construction could suggest a low status burial, or alternatively, a temporal change in funerary practices. The burnt remains of wooden grave goods and funeral biers placed on pyre structures may also have contributed to the charcoal content in the cremation deposit, but the use of such items at Four Crosses is unknown.

Although the melting point of copper is considerably lower than that of ironworking (for which the requisite temperature can only be achieved through the use of charcoal fuel), it is probable that the copper working dated to the Iron Age at Four Crosses also used charcoal fuel.

Fuel debris examined from the central group of pits showed differences between them. The primary fill of pit 23 I 3 indicated the selection of oak heartwood, whereas the primary fill of pit 2242, although mainly oak, also included alder, hazel and blackthorn. It is difficult to know if these differences are meaningful, although it is feasible that the activities associated with each pit related to different aspects of copper processing and thus fuel type.

A relatively narrow range of species was identified from the cremation and copperworking samples: oak, alder, hazel, blackthorn and elder. A number of other taxa were, however, present in the landscape (identified at the assessment stage): the hawthorn/ Sorbus group (Pomoideae), ash (Fraxinus excelsior), gorse (Ulex sp.)/broom (Cytisus scoparius) and willow (Salix sp.)/poplar (Populus sp.). The evidence suggests that throughout the Iron Age and Romano-British periods oak formed the dominant woodland cover, probably associated with ash and hazel. Wetland species included alder and willow and/or poplar. Open or scrubby areas would have supported species such as gorse/broom, hawthorn, blackthorn and hazel. Hawthorn and blackthorn may also have grown in hedgerows.

\section{POLLEN}

\section{by Katie Head}

Six sub-samples were taken, two from each monolith taken from the two phases of construction of Barrow 20 (Illus. IO) (see Wilkinson and Lewis, this article).

Pollen grains were counted, where possible, to a total of 250 land pollen grains (TLP), on a polarizing microscope at 400x magnification, and identification was aided by using the pollen reference manual by Moore et al. (I99I), and the author's reference collection. Nomenclature for pollen follows Stace (200I) and Bennett (I994).

With the exception of one sample, counts of 250 TLP (total land pollen) could not be achieved due to the degraded nature of the pollen grains and their low concentrations. 
CONTEXT 3 OIO, MONOLITH I 78

The monolith was from the buried ground surface beneath the first phase barrow mound. The lower sample within this context (9-IOcm) was dominated by Poaceae undiff. (grasses), making up almost 50\% TLP. Other herbs were dominated by Plantago lanceolata (ribwort plantain) and Scabiosa species (scabious), while Ranunculus acris-type (meadow buttercup), Caryophyllaceae (e.g. fat hen), Potentilla-type (cinquefoil), and Bidens-type (bur-marigold) were in very low numbers. Trees and shrubs only made up I6\% TLP, dominated by Alnus (alder), followed by Corylus (hazel). Other arboreal taxa included occasional examples of Quercus (oak), Salix (willow), and Tilia (lime). There were high numbers of Polypodium (polypody fern), and just one example of Calluna vulgaris (heather).

The upper sample of this context included similar taxa, but with a slight increase in the tree and shrub taxa seen in the previous sample. There was a significant fall in Plantago lanceolata (ribwort plantain), while other herbs were in comparable numbers to before, with the additions of Filipendula (meadowsweet) and Urtica dioica (common nettle). Polypodium (polypody fern) continued to be represented in high numbers although there was a slight fall in this taxon.

\section{CONTEXT $30 O 5$, MONOLITH I 77}

This monolith was taken from the turf line at the top of the secondary fill of the first phase barrow ditch, sealed by gravels of the extended second phase barrow. The lower sample, located at a depth of between I60 $\mathrm{mm}$ and $170 \mathrm{~mm}$, contained exceptionally degraded pollen grains in very low concentrations and counts of 250 TLP were abandoned. Therefore this lower sample could not be used in the interpretation except to note that it was dominated by Poaceae undiff. (grasses).

The upper sample (9-IO cm depth) contained better preserved pollen and counts of 200 TLP were achieved. Poaceae undiff. (grasses) made up 63\% TLP and so was the dominant taxon. Other herbs included Plantago lanceolata (ribwort plantain) and Scabiosa sp. (scabious) recorded in minimal numbers. Trees and shrubs contributed just $19 \%$ to the pollen sum. Alnus (alder) and Corylus (hazel) were in slightly greater values than other arboreal taxa, although Tilia (lime) was notable. As this latter taxon is under represented in the pollen record due to it being insect pollinated, lime would have been significant in the regional vegetation. Polypodium (polypody fern) was in significant numbers, and there was a single grain of Calluna vulgaris (heather).

\section{CONTEXT 5023 , MONOLITH I 79}

This monolith was from the turf line above the primary fill in the second phase barrow ditch and sealed by gravels eroding off the second phase barrow. Counts of between 200 and 250 TLP were achieved for the upper and lower sample. The lower sample (IoI I cm depth) was dominated by Poaceae undiff. (grasses) which made up 64\% TLP. Other herbs were as in previous contexts, with Plantago lanceolata (ribwort plantain) dominant but not as significant. Unlike context 3005, however, Scabiosa sp (scabious) was low in values comparable to ribwort plantain. Trees and shrubs were represented by species and numbers similar to contexts 3005 and 30I0, with the exception of Tilia (lime) which was absent. Polypodium (polypody fern) was also in high numbers. 
The upper sample (3-4cm depth) of context I 79 mainly comprised Poaceae undiff. (grasses), while trees and shrubs only contributed I0\% TLP. Other herbs were as in previous samples, although there was a large increase in Scabiosa species (scabious), overshadowing Plantago lanceolata (ribwort plantain). Polypodium (polypody fern) was still notable but less numerous.

\section{DIS CUSSION}

All three contexts appear to represent a substantially cleared landscape, dominated by grasses and herbs such as scabious. Clearance indicators were also present, particularly ribwort plantain. Trees and shrubs probably reflect a more regional component of the vegetation, with alder and hazel growing in wetter areas and the valley bottoms, while lime in particular would have been colonizing the drier lowland slopes. As palaeosols (see Wilkinson and Lewis, this article) then these samples appear to represent periods of stability in between the two phases of the barrow's construction. The pollen evidence from all contexts is very similar in species composition, possibly supporting the hypothesis of landscape stability. The presence of herbaceous vegetation including clearance indicators supports the idea that populations constantly used the site, and the large number of polypody ferns suggests this species was able to colonize the banks of the barrow between construction phases.

A number of Bronze Age barrows and cairns have been analysed for pollen in both the uplands and lowlands of Wales. Pollen sequences indicate that the Welsh landscape had been extensively cleared by the Bronze Age (Caseldine 1990). At the Bronze Age site of Cefn Gwernffrwd, near Rhandirmwyn in mid-Wales (Chambers I982a), the mixed oakhazel woodland was substantially cleared during this time, leading to an open landscape of grasses and ribwort plantain, comparable to the Four Crosses site. More recent investigations undertaken for the Prehistoric Funerary and Ritual Sites project has provided further evidence for widespread clearance activity and the development of grass and heathland on upland sites, and open grassland with secondary woodland at lower levels. In the locality of Four Crosses, evidence for grassland with some secondary woodland was indicated from the limited plant and charcoal remains from the ring ditches at Sarn-y-bryn-caled to the south of Welshpool and at Causeway Lane, near Llanymynech, whilst from Meusydd timber circles and a ring ditch Llanrhaeadr-ym-Mochnant a landscape of open grassland with some mixed woodland was indicated (Caseldine 2013, 299).

The evidence suggests the early Bronze Age Welsh uplands were characterized by the clearance of oak woodland and hazel scrub, which was replaced by Calluna heath (Chambers 1982b). At sites in the lowlands, following the construction of Bronze Age monuments, the landscape was newly dominated by grassland herb communities, which was the case at the Four Crosses site.

\section{THE GEOARCHAEOLOGY}

\section{by Keith Wilkinson and Helen Lewis}

Three $200 \times 70 \times 30 \mathrm{~mm}$ monolith samples were taken from strata buried beneath the mound of Barrow 20 (Illus. 5). The monoliths were studied to determine whether the 
fine-grained units sampled in the field were 'palaeosols' and to determine the nature of the soil-forming regimes.

\section{METHODOLOGY}

The stratigraphy revealed in the monoliths was photographed and described using standard criteria in the University of Winchester laboratory (i.e. Tucker I982, Jones et al. I999, Munsell Color 2000). Sub-samples for magnetic susceptibility measurement were then taken by removing Io $\mathrm{mm}$ thick by is $\mathrm{mm}$ wide slices from the left hand side of each monolith. These sub-samples were dried, homogenized and passed through a $250 \mu \mathrm{m}$ mesh. Sediment/soil coarser than $250 \mu \mathrm{m}$ was discarded, while finer material was used for high and low frequency magnetic susceptibility measurement using the methodology of Gale and Hoare (I99I, 22 I-6). Two of the monoliths (I77 and I78) were then passed to University College Dublin where two thin sections were made from each monolith and examined under high power microscopy.

\section{RES ULTS}

Two distinct phases of development of the barrow have been identified; the later phase increasing the diameter of the barrow and thereby in-filling the first ditch. All parts of the barrow mound were composed of Pleistocene gravels cast up from the surrounding ring ditches $\mathrm{A}$ and $\mathrm{B}$. These gravels were of pebble to cobble-sized sub-angular clasts in a medium sand matrix. They were decalcified. Three putative palaeosols were buried by the gravels at the following locations (Illus. 5):

(I) Beneath the first phase barrow mound (context 30I0): Monolith I78

(2) At the top of the secondary fill of the first phase barrow ditch and sealed by gravels of the extended second phase barrow (context 3005): Monolith I77

(3) Above the primary fill in the second phase barrow ditch and sealed by gravels eroding off the second phase barrow (context 5023): Monolith I79

Macroscopic laboratory description demonstrates that all three palaeosols have similar properties. Each comprises two sub-units, an upper consisting of a IO YR $5 / 6$ yellowish-brown silt/clay with occasional sub-rounded pebbles, and a lower of Io YR $5 / 4$ yellowish-brown silt/clay with moderate quantities of sand and a higher quantity of gravel than the overlying sub-unit. There are greater differences when the thin sections are observed microscopically. Four distinct layers were noted in Monolith I78 (context 3010):

Layer I: c. $40 \mathrm{~mm}$; loose reddish-brown fine crumb and intergrain microaggregate structure with frequent rounded and sub-rounded gravel $(5-20 \mathrm{~mm})$. In the lower IO-20 $\mathrm{mm}$ this is mixed with material from Layer 3 .

Layer 2: I-3mm; almost continuous layer of red clay, defining a sharp but irregular boundary between Layers I and 3 .

Layer 3: 20-30 mm; of denser yellowish-brown crumb and sub-angular blocky structure (5-IO $\mathrm{mm}$ ) with occasional rounded, sub-rounded and sub-angular gravel (2IO $\mathrm{mm}$, most $\left.<_{5} \mathrm{~mm}\right)$. Sharp wavy boundary to: 
Layer 4: 50-60 mm; layer of dense reddish-brown crumb (IO-I5 mm) and apedal structure (composed of densely packed microaggregates), with frequent gravel as in Layer I. This layer is physically surrounded by a zone of loose crumb and subangular to angular blocky aggregates $\left(0.3^{-} \mathrm{I} \mathrm{cm}\right)$, which appears to represent the disaggregation of the sample upon sampling or drying.

Layers I and 4 have similar groundmasses, components and pedofeatures. There are more faunal excremental features in Layer I (mite excrements and crumb peds) than Layer 4. The structural differences appear to relate mainly to compaction of the lower layer, and to increased bioturbation of the upper. Otherwise they were essentially the same material, and appear to represent an oxidized lower A horizon (i.e. former near surface layer) of a brown earth soil. At the base of Layer 4 there is slightly increased packing of gravels and frequent ped and grain coatings of the main soil groundmass. These indicate disturbance.

Layer 3 is greyish-yellow clayey silt that had been leached of iron, but was nevertheless enriched with clay in-filling pedofeatures. This is unusual in that although a leached horizon I is typical of mature brown earths, such soils are usually leached of clay as well as iron. E horizons are also usually underlain by B horizons (i.e. subsoil), but Layer 3 is underlain by a further A horizon that contains relatively few illuvial features. Comparing gravel sorting in Layer 3 with Layer 4, suggests that surface-casting earthworms may have been active in this profile; Layer 3 resembles an intermediate layer within an earthworm-sorted sequence. These observations suggest that the profile was stable and undisturbed for some time. However, the absence of a well-sorted casting layer normally associated with worm action may suggest that the upper part of the soil profile had been truncated.

There is a clear turf line visible in Monolith I77 (Layer 6), comprising dark reddishbrown sub-angular blocky and crumb peds (IO-I $2 \mathrm{~mm}$ size), and separating a IO-20 $\mathrm{mm}$ thick reddish-brown layer with fine gravels $(<8 \mathrm{~mm}$ ) (Layer 5), from a 30-40 mm thick layer of yellowish-brown soil with apedal crack and channel structure (Layer 7). The latter includes a stone line of gravels (3-17 mm size) in its upper Io $\mathrm{mm}$, but is otherwise stone-free. The boundary between Layers 6 and 7 is also marked by columnar structure over the first IO-20 $\mathrm{mm}$ of upper Layer 7 ; this is indicative of a clayrich soil. The lowermost $30-40 \mathrm{~mm}$ of the profile (Layer 8 ) is composed of yellowishbrown silt/clay with moderate to frequent rounded and angular gravels up to $20 \mathrm{~mm}$ in size.

Layer 5 comprises gravels in lower A horizon soil material, similar to that described for monolith I78 Layer I. Layer 6 is a thin upper A horizon, with moderate organic staining and indicators of earthworm activity. It appears relatively undisturbed, and has only a few textural pedofeatures, probably leached from overlying layers. The stone line underneath this layer, in the top of Layer 7 , could represent an earthworm sorting feature. Layer 7 is a weakly developed B horizon, with short cross-striated clay zones. With depth, this horizon shows increasing occurrence of clay and silty clay coatings. The $\mathrm{B}$ horizon continues into Layer 8 , which is distinguished by its gravel inclusions and some mixing with reddish-brown lower A horizon aggregates. 


\section{Glossary}

Ped: the solid structural unit of a soil i.e a soil particle or granule. Pore space or void separates them. There are 5 classes (granular, blocky, platy, prismatic and columnar) plus structureless.

Apedal: a soil without peds and therefore structureless, possibly because it is wet.

Palaeosol: or fossil soil is a soil that formed on a landscape of the past. They will usually be buried.

Terms specific to micro morphological analysis of soil thin sections:

Pedofeatures: discrete fabric units present in soil materials recognizable from an adjacent material by difference in concentration of a component or components.

Groundmass: the finer grained mass of material in which larger grained clasts are embedded i.e. the material left after the identification of the pedofeatures.

Intergrain microaggregate: Microstructures in which the solid units are a mixture of single particles (sand grains) and small aggregates of finer material, all separated by and defining complex packing voids. Or more simply: almost entirely sand-sized grains between which are micro aggregates of fine material.

\section{MAGNETIC SUSCEPTIBILITY}

Enough sub-samples were examined from reworked Pleistocene gravels to establish the magnetic properties of the parent material of the putative palaeosols. Low frequency magnetic susceptibility $\left(\chi^{1 \mathrm{ff}}\right)$ in these deposits varies between 25 and $50^{-8} \mathrm{~m}^{3} \mathrm{~kg}^{-1}$, while the percentage difference between low and high frequency magnetic susceptibility $\left(\chi^{\mathrm{fd}}\right)$ is between $3 \%$ and $10 \%$. In a mature soil higher $\chi^{\mathrm{f}}$ measurements would be expected in the $\mathrm{B}$ horizon than the $\mathrm{A}$ as a result of translocation of iron-rich clays from the overlying A horizon, however the magnetic properties of contexts (30IO) (monolith I78) and (5023) (monolith I79) vary little from that of the worked parent material, suggesting that both soils are immature. In contrast the low frequency magnetic susceptibility of context (3005) (monolith I77) exceeds $\mathrm{I}_{50}^{-8} \mathrm{~m}^{3} \mathrm{~kg}^{-\mathrm{I}}$ at $20-30 \mathrm{~mm}$ depth and then rapidly tails off to $c 30^{-8} \mathrm{~m}^{3} \mathrm{~kg}^{-\mathrm{I}}$ at 90-IOO $\mathrm{mm}$ (Illus. I 8). It is well known that pedogenesis leads to enhanced magnetic susceptibility in soils (Maher I986), but this usually occurs in the B horizon, which is not present in the monolith sample. Thus a cause other than soil formation has to be sought for the enhanced $\chi^{\text {lf }}$ readings. Given the magnitude of the readings the most likely mechanism is heat (Le Borgne I960). It is therefore likely that some form of burning took place on the surface of context $(3005)$ before it was sealed by the expanded barrow. Gradually diminishing $\chi^{\mathrm{f}}$ measurements from the peak at $25 \mathrm{~mm}$ depth suggest that the burning occurred at that level, impacted on underlying strata, while mixing (i.e. by earthworms or human disturbance) also transported heated particles upwards. Unfortunately the magnetic data alone cannot determine what form this heating took. 

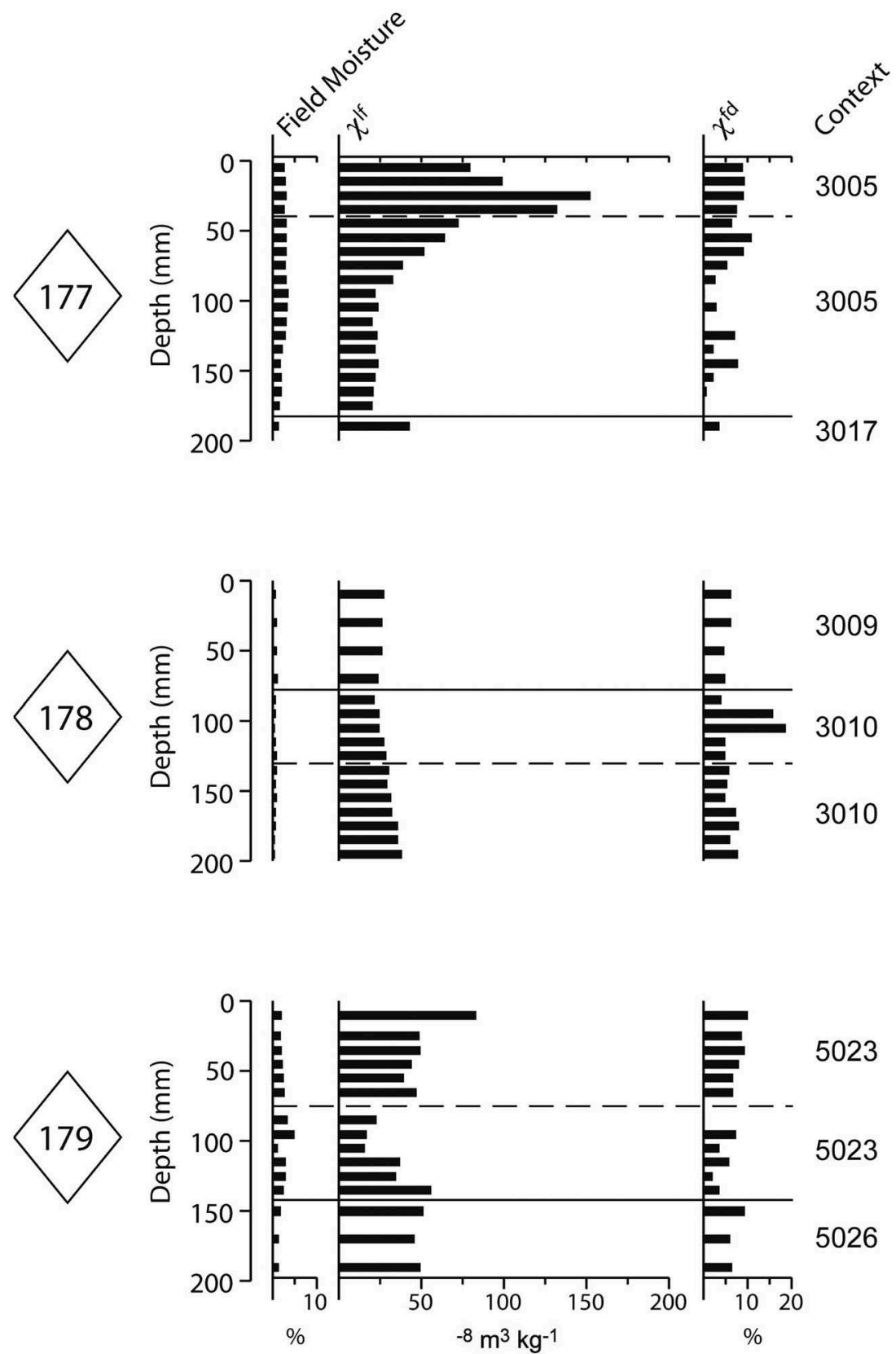

ILLUS. I8 Magnetic susceptibility of the palaeosols below the mound of Barrow 20 


\section{I S C USSION}

Field and laboratory description suggest that contexts (3005), (3010) and (5023) (monoliths I77-I79) are palaeosols that were buried by various stages of barrow construction. Characteristic soil forming features such as the developed horizons and clay translocation were noted, although features of mature soils are only present in context (3005). The evidence of magnetic susceptibility measurements in which readings in the A, and in the case of Monolith I78, B horizons are very similar to that of the parent material, suggest that all three soils are relatively immature.

The buried soil profile sampled in Monolith 178 has a complex developmental history. The maturity of the brown earth soil is difficult to assess given the contradictory information obtained from the thin section. Nevertheless it is clear that prior to the construction of the barrow the soil was stable and earthworms were active in the A horizon. However, the soil profile is likely to have been truncated, possibly as a result of deturfing for barrow construction. In the case of Monolith I77, the turf layer (A horizon) is thin, but the B horizon is relatively thick. The latter has been constructed from illuviated clay, suggesting a relatively long period of stability. These data would appear to conflict with observations made of the A horizon, perhaps suggesting that the latter has been truncated.

Taken together the macro and microscopic data suggest that construction of the original barrow took place on a stable land surface, but that this stability was a relatively recent phenomenon. It is clear from the micromorphological evidence that the prebarrow soil had been disturbed and perhaps that a previous soil of greater maturity had been removed decades or hundreds of years before barrow construction. Indeed the pollen evidence (see Head above) suggests that arable or grassland conditions predominated in the local environment, suggesting that early Holocene forests had been removed long before barrow construction. Low frequency magnetic measurements of context 3005 (Monolith I77) suggest that burning took place while the A horizons of this palaeosol was developing. This burning event is likely to be a result of cultural processes and most probably an effort to remove vegetation prior to the enlargement of the barrow.

\section{DISCUSSION: THE BARROW CEMETERY IN ITS WIDER CONTEXT}

\section{by Timothy Darvill}

The 2004-6 excavations and surveys provide a wealth of additional detail to expand understandings of the important round barrow cemetery at Four Crosses, one of a growing number of such cemeteries in Wales (Lynch I993, I44). Aerial photography in the I960s and '70s recognized about ten ring ditches and barrow mounds, but this increased to I6 as excavations between I98 I and I985 showed that not all extant ring ditches and mounds were visible as cropmarks (Warrilow et al. I986). The known extent of the cemetery has increased through the work in 2004-6 reported here, and on the Four Crosses Bypass in $20 \mathrm{IO}$ (Grant 20II), so that twenty-seven monumental components are now known, including five certain and three probable round barrows circumscribed by ring ditches together with sixteen further ring ditches that in some 
cases might also have once enclosed barrows. Further important additions comprise pits and graves between the monuments. Other structures and features no doubt await discovery. Over the same period, work at barrow cemeteries across the British Isles and beyond has emphasized their longevity, the importance of considering their landscape settings, and exploring their wider cultural connections (Last 2007; Leary et al. 20I0; Anon. 20I3; Darvill 20I3, I44; Fontijn et al. 2013). Large-scale excavations have also revealed the widespread presence of flat graves and other features between and around the main barrows, as well as open areas for ceremony and ritual (e.g. Barclay and Halpin I999; Harding and Healy 2007; Bourgeois 2013). As a result, there is increasing interest in the role of barrow cemeteries as places for the living: arenas for the performance of a wide range of ceremonies and festivals that mythologized and dramatized prevailing world views (Garwood 2007a). Exactly what such cosmologies comprised is hard to visualize now, but one scheme that has been proposed for the European Bronze Age sees a universe in which the gods inhabited three levels - the sky, the earth, and the waters under the earth - conceived as circular planes that wheel eternally around an axis mundi (Kaul I998; 2004; Kristiansen and Larsson 2005, 357). The living inhabited only the middle plane, while the dead inhabited the underworld that was accessible through liminal zones and disjunctions at the intersections of earth, sky, and water; it is here that barrow cemeteries and the activities that took place at them were crucial for Bronze Age communities.

The Four Crosses barrow cemetery extends over an area approximately I600 $\mathrm{m}$ east to west, by $500 \mathrm{~m}$ north to south. Appendix A summarizes what is known of the barrows identified to date; Illus. 20 shows the distribution of component mounds and ring ditches in relation to local topography. It is essentially a linear cemetery (Woodward 2000, 78-9) with the barrows arranged along a rather ragged south-west to north-east axis centred on Barrow 5. Whether this axis should be seen as a single line of barrows or as two lines flanking a ceremonial pathway or avenue as suggested for Barrow Hills, Oxfordshire (Barclay and Halpin I999, fig. 9.8), is impossible to say in the current state of knowledge. Present evidence does suggests two further lines of barrows extending southwards from the main axis, one at either end, with the 2004-6 excavations focused on the south-western branch.

Like many linear cemeteries there is a close association with water. Four Crosses occupies a low gravel terrace overlooking the Afon Vyrnwy, which here flows southwest to north-east in a meandering channel roughly parallel with the axis of the cemetery about $500 \mathrm{~m}$ to the south of the river (Illus 20 and $2 \mathrm{I}, \mathrm{A}$ ). The exact course of the river in prehistoric times is not known, but the coincidence between the movement of water and the main axis of the cemetery can perhaps be linked symbolically to the passage of the sun from west to east through the watery underworld during the hours of darkness (Kaul I998; Darvill 20I0, 226). It is a pattern seen at round barrow cemeteries elsewhere in eastern Wales (Gibson 2002) and the mid-west of England (e.g. Garwood 2007b). About $2 \mathrm{~km}$ to the north-west of Four Crosses, on the northern glaciofluvial terraces of the Afon Vyrnwy, is the Llanymynech barrow cemetery comprising at least seven barrows/ring ditches over a distance of about $\mathrm{I} 200 \mathrm{~m}$ parallel to the Afon Vyrnwy (Illus. 21, B). Like Four Crosses it has a complicated pattern of investigation. A small ring ditch about $\mathrm{I} 2 \mathrm{~m}$ across at Elmtree Farm near the eastern end 
of the cemetery was partially excavated in 1992 (Gibson I992) and fully excavated in 2007 , but no central burial was found. A group of cremation burials lay to the west, some in stone cists, with associated Food Vessel and Collared Urn pottery and radiocarbon dates in the early second millennium BC (Colls and Halsted 2009). A third ring ditch at Causeway Lane, much larger than the others at about $57 \mathrm{~m}$ across, was sampled in 2010 as part of a wider study of similar sites in Wales. Radiocarbon dates on charcoal from the primary ditch fills of 3950-3800 cal. BC (SUERC-43274: 5066 $29 \mathrm{BP}$ ) and 3340-3030 cal. BC (SUERC-43275: 4483 29 BP) suggest it was constructed in the later fourth millennium BC but no evidence of burials or the use of the site was recovered (Britnell and Jones 20I2, I69-73). The linear ring ditch cemetery at Banhadla, Llangedwyn, in the Tanat Valley has many similarities to the arrangement at Four Crosses (Gibson 2002, fig. 9). To the south at Sarn-y-bryn-caled/Dyffryn Lane, Powys, a linear ceremonial complex runs parallel to the River Severn, here flowing south-west to north-east (Gibson I994; 2010), and at Bromfield, Shropshire (Illus. 22, C), a linear cemetery of about twenty barrows lies parallel to the north-west to southeast-flowing Rivers Onny and Teme (Stanford I982, fig. 2; Garwood 2007b, fig. I0.6). Further afield parallels include an extended cemetery beside the River Nene at Raunds, Northamptonshire (Harding and Healy 2007, fig. I.4) and beside the Great Ouse at Roxton, Bedfordshire (Taylor and Woodward I985) and Over, Cambridgeshire (Garrow et al. 20I4). Unusually, the cemetery at Barrow Hills, Oxfordshire, parallels, albeit at a distance of about $2 \mathrm{~km}$, a section of the River Thames that flows east to west (therefore not mirroring the passage of the sun) rather than on its dominant course west to east (Barclay and Halpin I999, figs. I.I and I.3; Illus. 22, D).

At Four Crosses people were clearly using the terrace of the Afon Vyrnwy at an early date. The presence of worked Mesolithic flints combined with seemingly residual charcoal dated to 6360-5920 cal. BC (CAR-849: 7250 $\pm 90 \mathrm{BP}$ ) and 5980-5720 cal. BC (CAR-850: 6990 $\pm 80 \mathrm{BP}$ ) from Barrows 2 and 8 respectively imply a focused episode, although what kind of activity was involved can only be guessed. The foundation of the barrow cemetery came several millennia later and may have involved the sub-circular pit 2548 containing Grooved Ware in what would become the southwestern corner of the cemetery. It was in just such a position that a series of intercutting pits containing Grooved Ware pottery were found at Barrow Hills, Oxfordshire (Barclay and Halpin I999, 302), and at Winterbourne Stoke Crossroads, Wiltshire, where a long barrow occupies this position (Grinsell I978, I8). Indeed, Ros Cleal $(1999,6)$ has explored the seemingly widespread connection between features containing Grooved Ware and round barrows to conclude that there was a preference for putting Grooved Ware in the ground at sites subsequently used for the construction of barrows. How exactly knowledge of these deposits was perpetuated and then used to inform later activity remains to be explained.

The first barrow - the 'Founder's Barrow' - at Four Crosses appears to be Barrow 5, a Neolithic round barrow well outside of the main distribution of recorded examples in Britain (Kinnes I979, fig. 4.2). Within the cemetery it stands $550 \mathrm{~m}$ west of what would later become the main focus of activity (see Illus. 20). Burials placed in the central shaftgrave can be loosely dated to 3340-29I0 cal. BC (CAR-670: 4440 \pm 70 BP), which accords well with the pottery from Phase I of the barrow (Warrilow et al. I986, 63-8). 
As with other round barrows of the late fourth and early third millennia BC, the cemetery element of the site involved the successive reuse of a single mound. Culturally, this monument connects with the round barrows of central and eastern England. Of rather similar date is Duggleby Howe, North Yorkshire, whose primary burial (Burial K) in a rock-cut shaft $2.7 \mathrm{~m}$ deep was associated with fragments of decorated bowl dated to 3630-3370 cal. BC (mean of OxA-I675I (470I $32 \mathrm{BP}$ ) and SUERC-I $3938(4675 \pm 35 \mathrm{BP})=4689 \pm 24 \mathrm{BP})$, and found with nine flint flakes, and two flint cores (Kinnes et al. I983). Other round barrows covering shaft graves include Willie Howe, North Yorkshire, with a multiple disarticulated burial within a shaft dated to around 2000 BC (Gibson and Bayliss 2009, 95-6), and Octon Wold, North Yorkshire, with two centrally placed shaft-graves both of later third millennium BC date and associated with Beaker traditions (Gibson and Bayliss 2009, 97). All these sites, and others beside, form part of a widespread tradition of earth-cut burial pits under round barrows, whose immediate origins lie eastwards across the North Sea in the Corded Ware traditions of southern Scandinavia and the North European Plain. Indeed, oxygen isotope analysis of Burial K from Duggleby Howe shows that the person was not local and may have come from as far afield as the Hebrides, western Cornwall, the Paris Basin, or Denmark (Gibson and Bayliss 2009, 73).

Once established, the Four Crosses cemetery became a focus of burial rituals for nearly three millennia, one of several such foci in the area (Gibson 2002; Colls and Halsted 2009). It is tempting to separate activities into period-based horizons, and archaeologically this makes sense. However, the likelihood is that the development of the site was far more fluid with episodes of heavy use separated by periods when nothing much happened. It is quite likely that a single community used the site over many generations and may have regarded it as their ancestral cemetery in a way that created a family or kindred's biography in monumental form (Last I998). The enlargement and refurbishment of Barrow 5 in the early second millennium BC marks an important event in the history of the cemetery, and may tentatively be associated with activities in the surrounding landscape by users of Beaker pottery. The presence of a pit containing Beaker coarseware and fineware sealed below Barrow 2, and residual Beaker pottery and associated flintwork from the matrix of later mounds forming Barrows 5 (phase 3) and 7, and the ditch fills of Barrow 5 (phase I), illustrate how widespread activity might have been at this time. Periodic visits to the site within a wider cycle of tethered mobility is a possibility (cf. Fleming I97I) and as such may represent the perpetuation of such a tradition in area well represented by the upland settlement at Trelystan, Powys, that was intermittently frequented by a Grooved Ware-using community in the early third millennium cal. BC (Britnell I982).

An important change was the shift from using Barrow 5 as the focus for successive burials with associated elaborations of the mound (i.e. a cemetery mound), to a pattern of creating new barrows and flat graves as different needs arose (i.e. a cemetery of barrows). Current dating evidence suggests that from Barrow 5 as an established starting point, strings of mounds developed south-westwards towards the recently discovered Barrow 27 (Grant 20I I; Illus I9 and 20) and northeastwards towards Barrow 7 broadly mimicking the course of the Afon Vyrnwy up-stream and down (Illus. 20). Such a scheme, in which one or more nodal barrows stand at the physical and temporal head of 


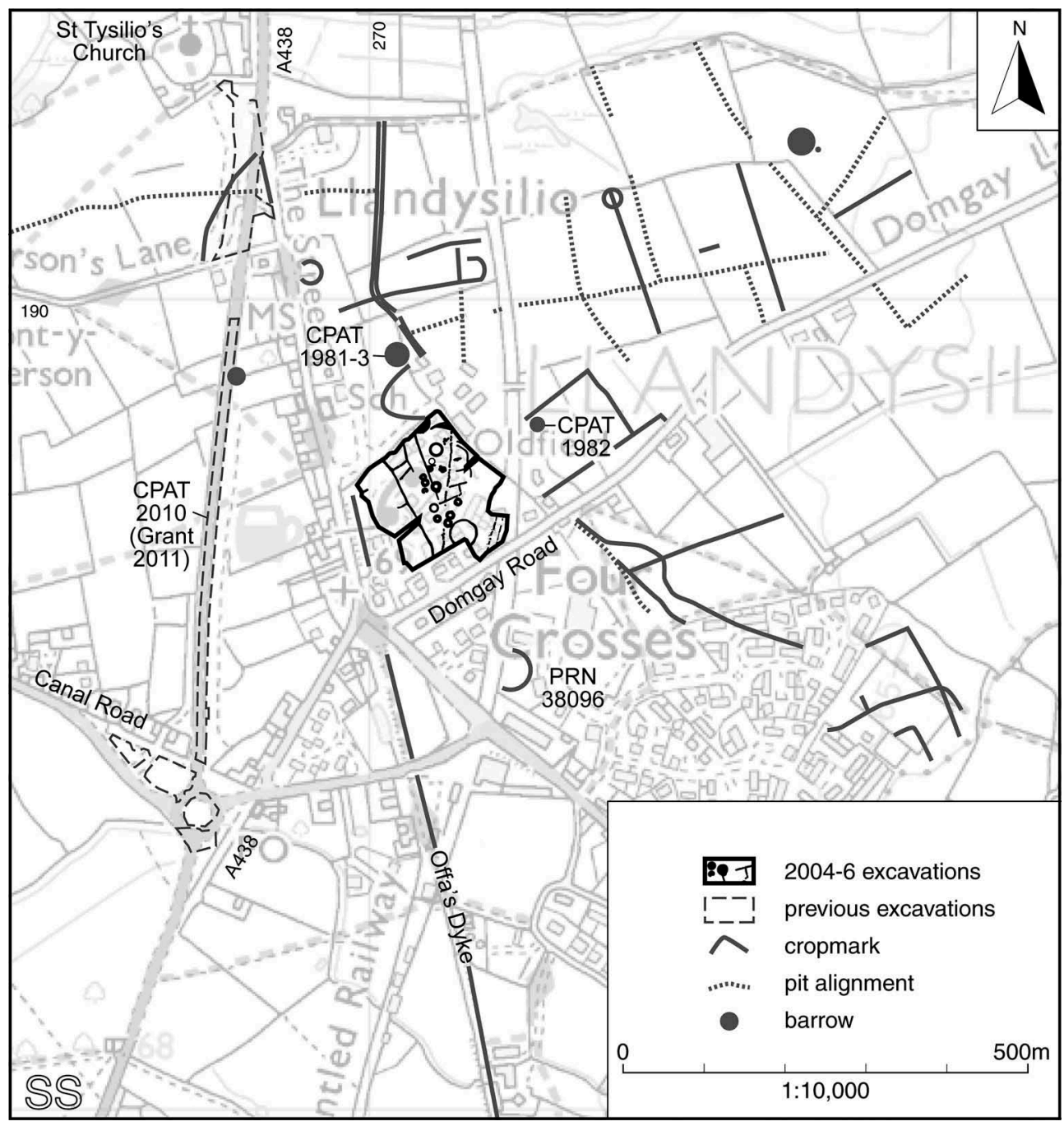

ILlus. I9 The 2004-6 excavations, other sites and cropmarks at Four Crosses (after Marches Archaeology 2003)

incrementally extended lines of barrows accords well with the way that barrow cemeteries can be seen to have developed elsewhere in Britain (Mizoguchi I992; Garwood 2007a, 43). An exception to this trend is the Winterbourne Stoke cemetery where one sequence of barrows construction appears to have headed towards, rather than away from the earlier long barrow (Bowden et al. 20I5, 6I-2). To what extent different kinds of barrow are represented at Four Crosses is hard to gauge because preservation is poor, but there is clearly much variety in the size of the mounds and it is tempting to see the presence of fancy barrows (small barrows with a wide berm 


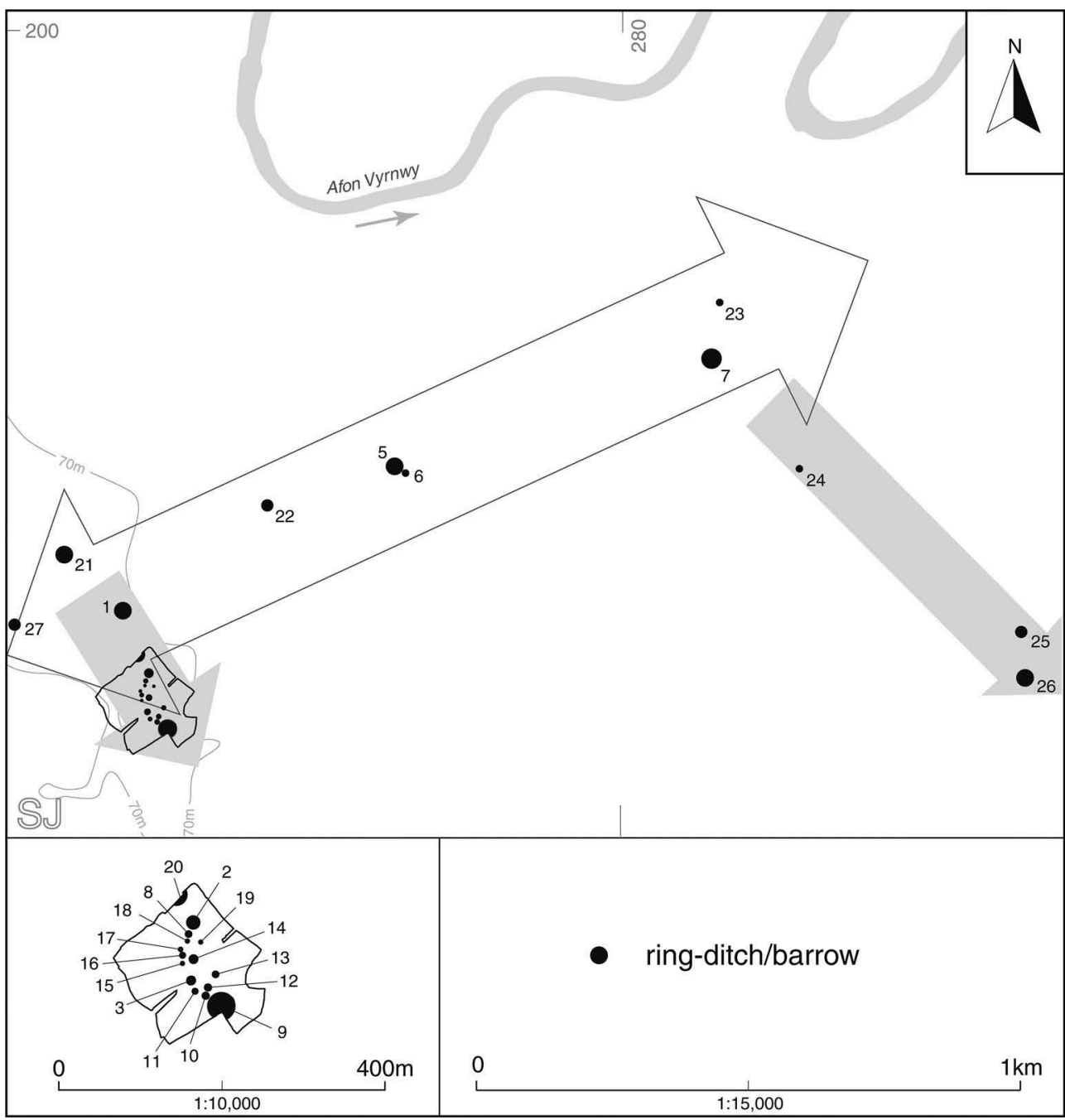

ILLUS. 20 Four Crosses linear barrow cemetery in relation to the Afon Vyrnwy with arrows indicating the principal axis and developmental trends. (after: Warrilow et al. I986, fig. I with additions)

between the mound and surrounding ditch) (?Barrows I and 7) alongside the more ubiquitous bowl barrows.

Through the first half of the second millennium BC the Four Crosses cemetery was probably at its most monumental. Barrow 27 within a ring ditch some $23 \mathrm{~m}$ across covered a central burial pit that contained, towards the northwestern end, a deposit of cremated bone dated to 2030-I770 BC (SUERC-342I7) (Grant 20II). An elaborate barrow (Barrow I) with concentric stake-circles was built at the western end of the cemetery soon after $2000 \mathrm{cal}$. BC. At about the same time the putative founder's barrow 
(Barrow 5) was extended for a third phase, now also with a stake circle bounding the enlarged mound. Such structural modification and the mimicking of different barrow types within the same cemetery is seen by Andrew Martin (20I I, 69) as evidence for conflicts and tensions between the communities responsible for making, maintaining and using different mounds, in which each group is establishing and asserting their particular identity through the medium of monument architecture. However, there is also a degree of unity and common purpose expressed by the mounds and the features archaeologically represented. A central post-hole dated to I900-I530 cal. BC (CAR666: $3420 \pm 65 \mathrm{BP}$ ) cut the fill of the central grave-pit at Barrow I near the southwestern end of the cemetery and a central post-hole was also recognized at Barrow 7 near the north-eastern end of the cemetery (Illus. 20). From a practical perspective, these posts might be considered as temporary markers to help lay out the barrow or the axis of the cemetery. Symbolically, conversely, they could represent in a very tangible sense the vertical dimension to underlying cosmological beliefs - the axis mundi around which the barrow was built. It might be suggested that the barrow was built to represent the vault of the heavens over a now-sacred circular patch of ground into which a pit had been dug in order to physically situate the corpse within the underworld.

Unaccompanied inhumations not covered by mounds were probably present around and between barrows, but the poor survival of bone at the site makes the understanding the burial rituals very difficult. Two burials at the northeastern edge of the 2004-6 excavations, north-east of Barrow I3, were cremations, one dated to I900-I730 cal. BC

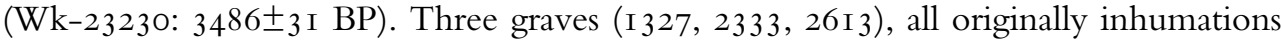
on the basis of the cut sizes, lay in between Barrows 9 and 20. Grave I 327 contained an amber bead, further emphasizing connections eastwards to the coastlands of the North Sea (Beck and Shennan I99I). Pottery of the early second millennium BC is rare at Four Crosses and the cultural affinities of the user-communities at this time are hard to determine. Across the Afon Vyrnwy at Llanymynech, excavations at Carreghofa Lane in 2007 also revealed four seemingly unmarked cists and a cremation pit west of a ring ditch (Colls and Halsted 2009, 74-80). Here, though, a locally made Food Vessel was found in one cist, while an inverted Collared Urn associated with cremated bone dated

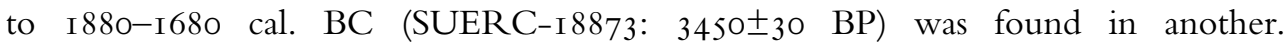
Unassociated cremated bone from another nearby cist was dated to $1920-1730 \mathrm{BC}$

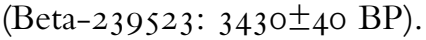

The penannular form of Ring Ditch A bounding the first phase of Barrow 20 suggests this was meant to be an accessible space within the developing cemetery, perhaps for ceremonies, rather than a fully enclosed inaccessible space. The presence of a pit $(3025)$ cutting into the primary mound of Barrow 20 also suggests accessibility, and it is notable that pits were also recorded cutting the ditches of Barrows 5 (phase 3), 7, and I3. Moreover, it is possible that some of the ring ditches, perhaps Barrows 3, 9 and I I never enclosed a barrow or a central burial at all, but instead were simply open round enclosures. The ring ditch excavated at Carreghofa Lane, Llanymynech (Colls and Halsted 2009, 7I-4) defined an internal space $\mathrm{I} 3 \mathrm{~m}$ across by means of a V-profile ditch $2.2 \mathrm{~m}$ wide and I $\mathrm{m}$ deep but no internal features or secure evidence of a mound was found. Such enclosures, and also mounds with no underlying burials, have been 
noted at various barrow cemeteries in Britain (Lynch I993, 44-6) and their incidence and interpretation deserves further research.

Cremation burials were probably deposited in Barrows I, 3, 5, and 7, where pieces of broken bucket and globular urns of the local middle Bronze Age variant of DeverelRimbury traditions are represented in eroded mound material and topsoil. Whether these had been inserted into existing mounds or were incorporated into expanded or even newly-built mounds is not known. Erosion of the barrows has been such that none of these urns survived in situ, and it has to be accepted that more such burials might have been lost entirely.

Small barrows are a late feature of most excavated barrow cemeteries in Britain, and at Four Crosses take the use of the site well into the first millennium BC. At the Long Barrow Crossroads cemetery, Winterbourne Stoke, Wiltshire, a cluster of small late barrows can be seen forming a spur at right-angles to the main axis of the linear cemetery towards the north-eastern end (Bowden et al. 20I5, fig. 4.8). At Four Crosses, the ten small ring ditches or barrows in a narrow band between Barrows 9 and 20 show a similar arrangement. The grave in Barrow I4 was dated to 2 IO-4O BC (Wk-23236: 2104 $\pm 32 \mathrm{BP}$ ), while a finger ring of Iron Age date was found in the grave central to Barrow I5. A cremation burial (Cremation 3) tentatively associated with Pit

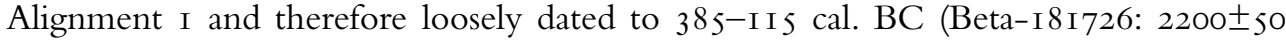
BP) suggests the continued use of the area for burial even though the barrow cemetery as such was long abandoned (Illus. 23).

By the middle of the first millennium BC the area occupied by the barrow cemetery was hosting a range of other activities, some of them typically liminal and thus appropriately situated within an existing cemetery zone. Copper smelting dated to 370-I IO cal. BC (Wk-23232: 2I8I土30 BP) and 260-IIo cal. BC (Wk-23233: 2I63 $\pm 30 \mathrm{BP}$ ) on the basis of charcoal from Pit 2242 containing waste material from the process. Bronze-working was recognized at Barrow 2 during the excavations in I984 (Warrilow et al. I986, 60-I), and graves 2-6 in the same barrow may also date to the later first millennium BC. Taken together, these finds perhaps emphasize the way that, in some areas at least, metalworking in later prehistoric times was sometimes done away from settlements at remote unearthly places by itinerant communities who were considered outside mainstream society.

With the construction of the pit alignments across the site the area was divided up in a new way. Although perhaps aligned on particular barrows extant at the time of construction (Wigley 2007, I22), the main axis of the system does not really follow the south-west-north-east axis of the barrow cemetery, but rather weaves its way through the disposition of barrows and ring ditches suggesting a practical respect for extant features in the landscape even if the meanings and significance of them had been lost. The same applies to the alignment running through the south-western arm of the barrow cemetery excavated in 2004-6 and reported here. When exactly the pit alignments were constructed, and how they were used, is problematic not only in eastern Wales (Wigley 2007) but also across the British Isles (Wilson I978). At Four Crosses, something of the extent and co-axial pattern to the alignments is known through aerial photography, while investigations of several sections provide detailed information through geophysical survey (Halsted 2007) 

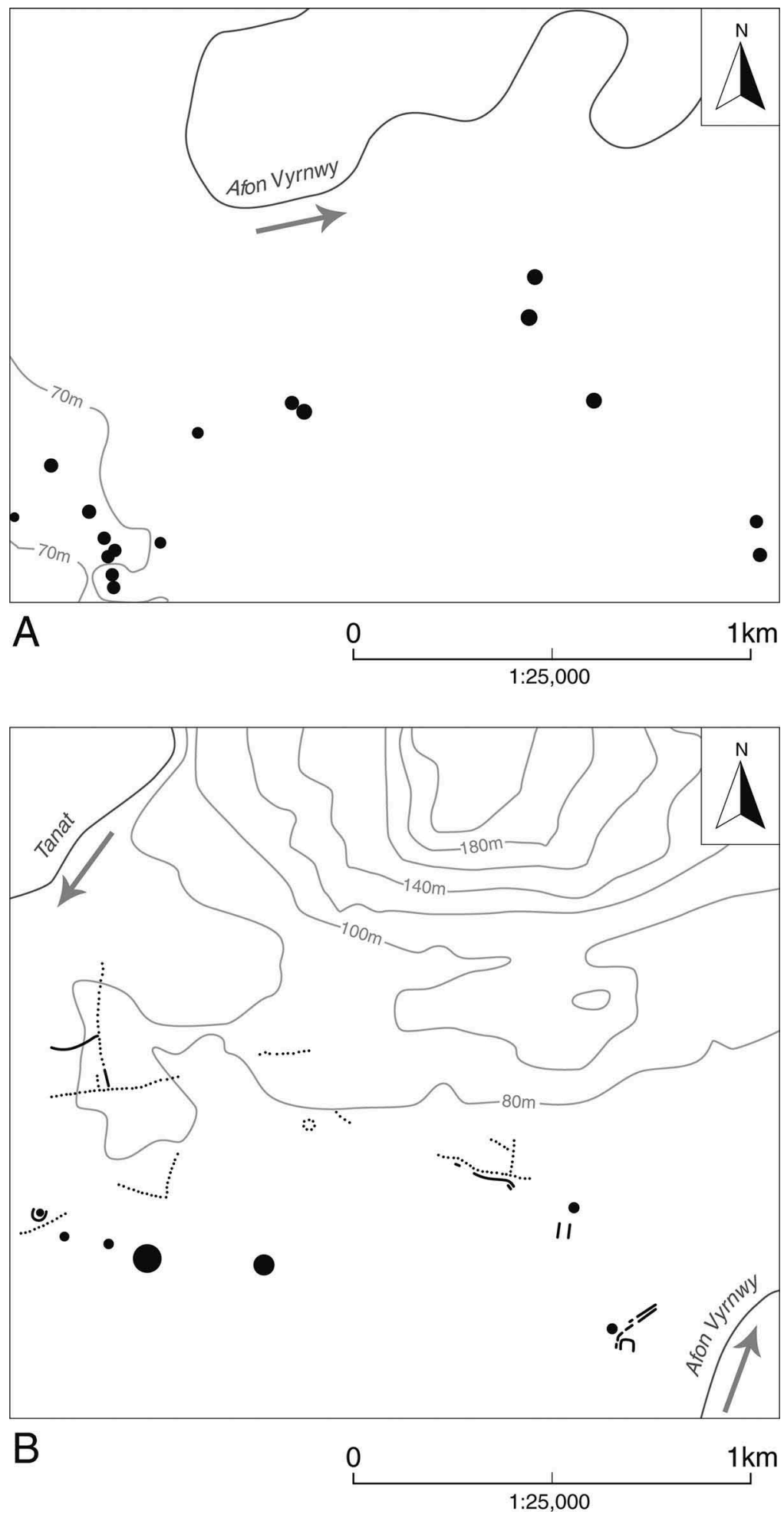

ILlus. 2 I Linear barrow cemeteries. A: Four Crosses, Powys. B: Bromfield, Shropshire. (after: A. Warrilow et al. I986, fig. I with additions; B. Stanford I982, fig. 2) 

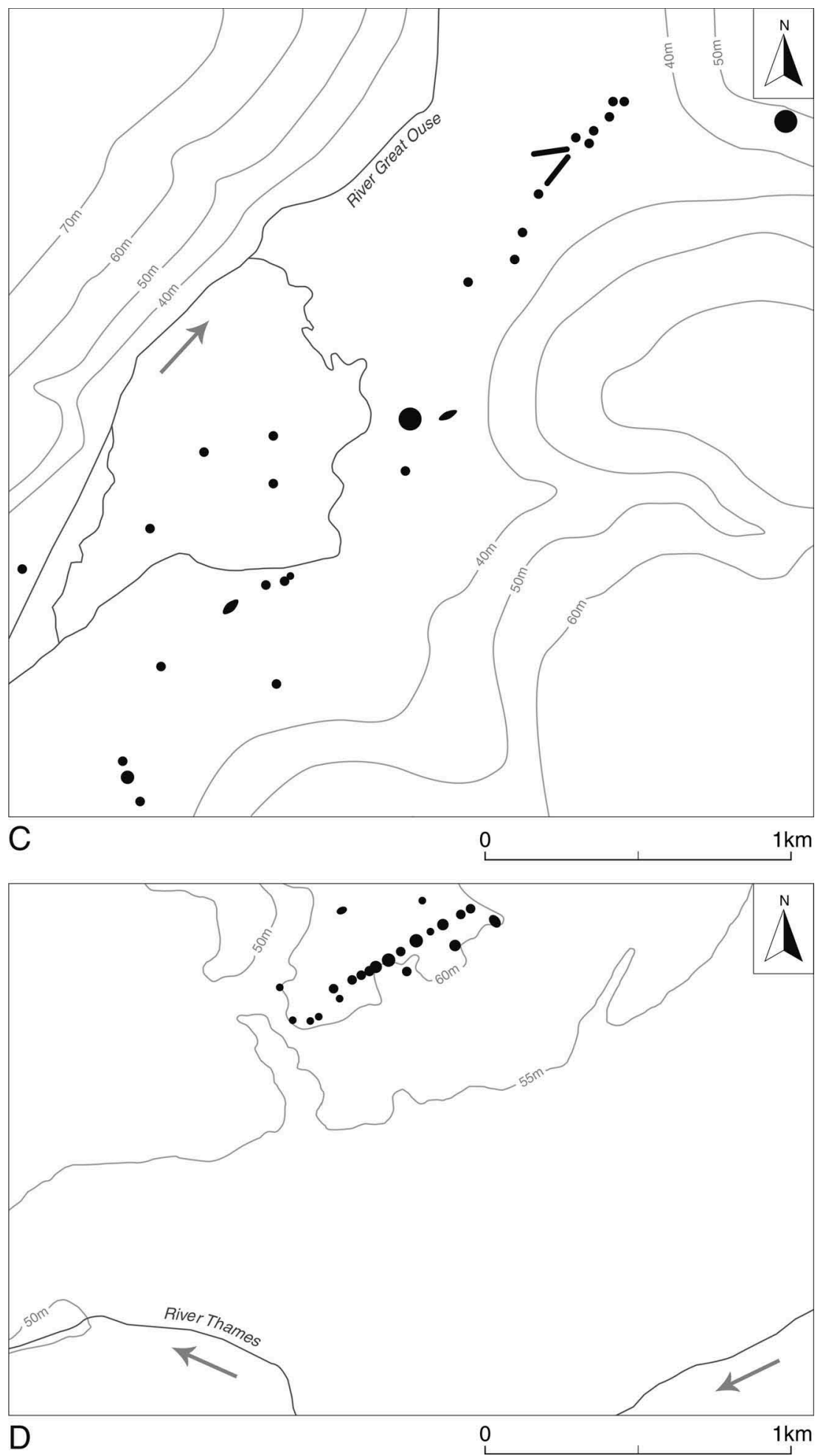

ILlus. 22 C: Raunds, Northamptonshire. D: Barrow Hills, Oxfordshire. (After C. Harding and Healy 2007, fig. I.4; D. Barclay and Halpin I999, fig. 9.9) 


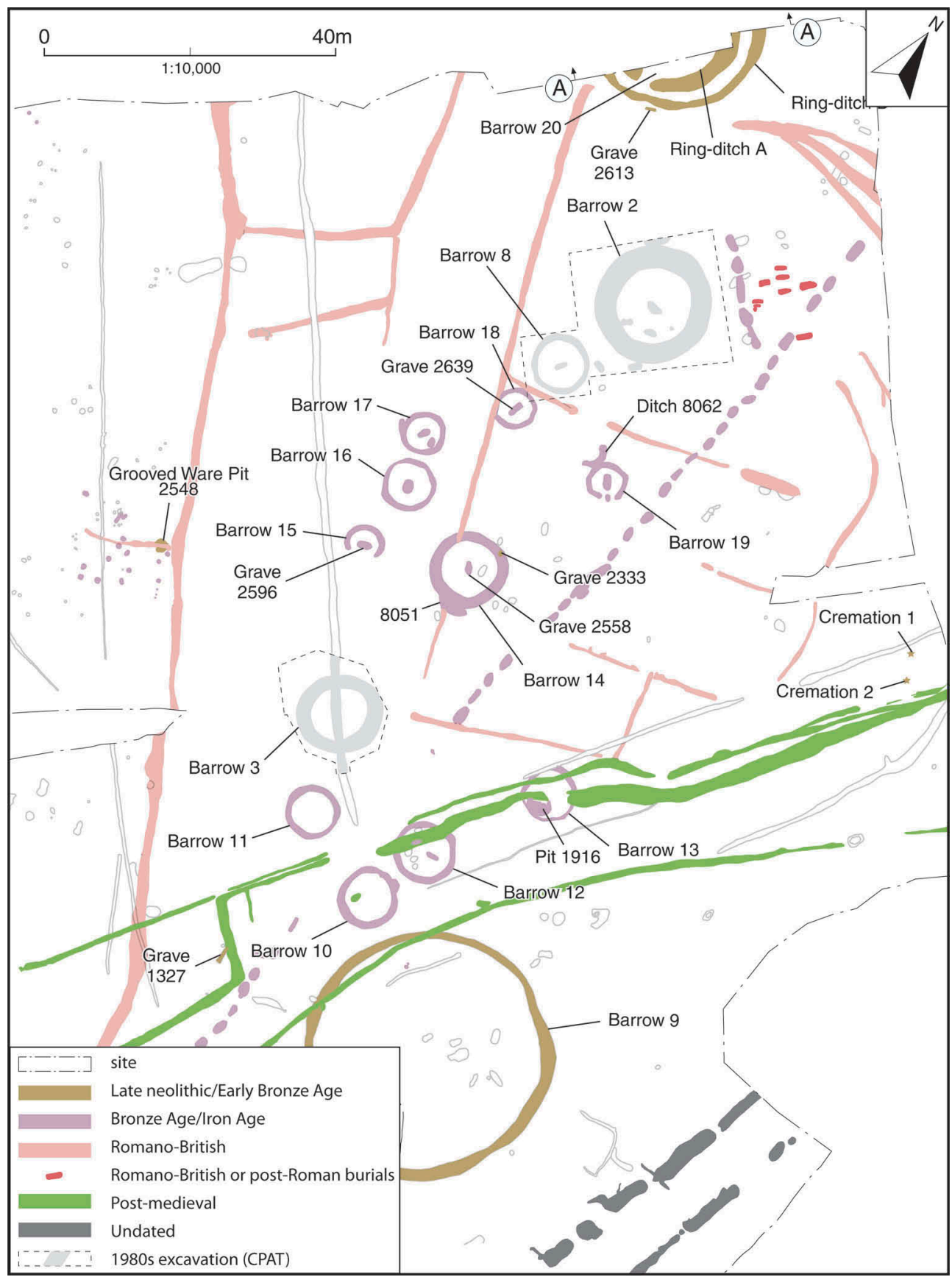

ILLUS. 23 Tentative phasing scheme for the excavations 
and excavations (Warrilow et al. I986, 55; Owen and Britnell I989), the 2004-6 work at Domgay Lane reported here, and on the line of the Four Crosses Bypass (Grant 20I I, 89; Illus. I9). As discussed above, dating evidence for Pit Alignment I is sparse, but a gap in its course seems to respect Barrows 3, IO, II, and I2 suggesting that it is later than the early Bronze Age; it is certainly older than the Roman field systems, and the pits had probably filled up by the Middle Iron Age to judge from the presence of Cremation burial 3 which may be residual in the fill of a fairly isolated pit (Illus. II). This accords with evidence from the Four Crosses Bypass which suggests that individual components of the pit alignment investigated here had filled-up by the middle of the first millennium BC (Grant 20I I, 89). An analysis of pit alignments across eastern Wales and the Welsh Marches suggests that they related to projects in the early part of the first millennium BC involving shared labour to create communal identities at a scale greater than that of individual neighbourhoods (Wigley 2007). Cropmarks suggest the Four Crosses pit alignments extend as far as Domgay Lane (Owen and Britnell I989; Illus. I9) and the vestiges of pit alignments to the north of the Afon Vyrnwy at Llanymynech may belong to the same scheme (Illus. 2I, B).

A continued awareness of the barrow cemetery is also evident in Romano-British times. The principal boundary of Field System I runs between Barrows I 4 and 20, but does not slight them. In addition, although it must be presumed that the field division suggests use of the site for agrarian purposes, some significance above the purely practical is suggested by the citing of the small cemetery immediately to the east of Barrow 2. Whether the cremated remains excavated from the Romano-British ditch reflect Roman cultural influence, or a more ancient tradition cannot be determined. Given the dispersed distribution of the earlier cremations, it is also possible that this cremation is the re-deposited remains of a pre-Roman cremation disturbed by Roman agricultural activity.

The small cluster of inhumations respects the earlier pit alignments, in that the burials do not cut through them, and the Romano-British pottery found within Grave 255I suggests burials in the Roman period. There are three examples of single extended burials in pre-conquest Wales (Pollock 2006, 20), but discrete clusters of extended inhumations with a common alignment, defined as 'managed' cemeteries (Thomas I98I) reflect Roman influence and are found from the midsecond century AD onwards near forts and vici, predominantly in South Wales. This type of cemetery however, is not identified at rural locations until later in the Roman period, typically from the third century onwards. The earliest of these is at Abernant, Monmouthshire, dated to the second or third century AD, where notably, there is also a cremation burial of possible Roman date (Tuck et al. 2003). There are few examples of extended burials of this period in mid or North Wales; the reduction of military activity from the mid-second century onwards in these regions may have put a brake on the spread of Roman cultural influences, which were in any case slow to be adopted in the more rural locations. None of the late Roman inhumations of mid- or North Wales are securely dated. Accompanying grave-goods are characteristically absent from this type of cemetery, and the destruction of human bone by acid soils has limited opportunities for radiocarbon dating. A 
late Roman phase has been tentatively identified at a few early medieval cemeteries, such as Plas Gogerddan, Ceredigion (Murphy I992, 27) where a radiocarbon date of

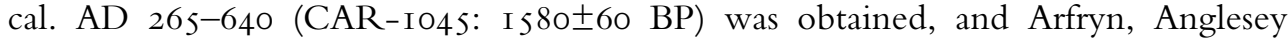
where late fifth/early sixth-century burials were preceded by an earlier phase of undated burials on a different alignment (White I972, 35; Petts 2002, 35). A late Roman phase has also been postulated for Capel Eithin, Anglesey (Pollock 2006, 75). Despite the influence of Roman burial traditions on the inhumation cemetery at Four Crosses, the siting of the cemetery amongst the monumental earthworks of an earlier time reflects a desire to be associated with a more ancient indigenous lineage.

Consideration must be given to the possibility that the cluster of inhumations at Four Crosses are post-Roman. Post-Roman burials are not numerous in North Wales, but include examples of cemeteries found in association with earlier features including prehistoric monuments, such as the three cemeteries mentioned above, and a small cemetery at Trelystan, Powys considered to be post-Roman (Britnell I982). Trelystan has particular similarities with Four Crosses, in that the inhumation cemetery is within a complex of prehistoric monuments which lie to the east of Offa's Dyke, and the later burials are also positioned on the eastern side of an earlier barrow. The north-east-southwest alignment of the burials at Four Crosses relates most closely with the pit alignments and Romano-British Boundary Ditch I, but if the burials are post-Roman, the proximity of Offa's Dyke to the west may also have been a factor in their location. The discovery of an iron javelin and spear with sixth to seventh-century parallels in the upper filling of the ring ditch of Barrow 2 (Warrilow et al. I986; Barford et al. I986) testifies to a postRoman engagement with these prehistoric monuments. Weapons of fifth to seventhcentury date inserted (possibly thrust) into earlier monuments has been noted elsewhere and viewed as analogous with the deposition of weapons into rivers; a dramatic demonstration of both power and ownership (Semple 2013, 78-82). The course of Offa's Dyke has been much discussed in terms of its use of the natural topography of the area to create a symbolic and defendable frontier between Mercian control and the traditional territories of the Kingdom of Powys to the west (Ray and Bapty 20I6, I3 I-2). From the high ground to the west it would also be apparent that the Dyke now separated the visible remains of the barrow cemetery from these territories, and from the populations who may have previously claimed them as their ancestral grounds (although the barrow identified on the Four Crosses by-pass lies to the west of the course of the Dyke (Grant 20I I)). Subsequent use of the barrow cemetery for inhumations and other rituals would serve to reinforce control of these borderlands which had offered considerable resistance to Mercian expansion (Ray and Bapty 2016, 362).

\section{ACKNOWLEDGEMENTS}

The fieldwork was undertaken on behalf of Jennings Homes (now David Mclean Homes) at the request of Waterman CPM and subsequently the Environmental Dimension Partnership. Elan Homes generously funded the post-excavation work. We are grateful to Royston Clark, Andrew Crutchley and Shaun McCarthy for their support. The site was monitored by Mark Walters of Clwyd-Powys Archaeological 
Trust Curatorial Section, and we are grateful for the support of the Trust during the course of the project.

The project was managed for Cotswold Archaeology by Mark Collard and Mary Alexander, directed in the field by Tim Harvard, supported by Dave Cudlip and a team of dedicated excavators. The post-excavation project was managed by Annette Hancocks and Mary Alexander. Pete Moore and Jonathan Bennett prepared the illustrations, which were edited by Sam O'Leary. Teresa Gilmore undertook the preliminary analysis of the human remains. Timothy Darvill usefully commented on the presentation of the results in this report, and Neil Holbrook of Cotswold Archaeology and Mark Walters of Clwyd-Powys Archaeological Trust Curatorial Section commented upon an earlier draft of this report. The project archives and finds will be deposited with Powysland Museum (Welshpool) under accession number $\mathrm{A}_{4} 67 / 2005$.

\section{B IB LIOGR A P H Y}

\section{ANCIENTSOURCES}

Tacitus, Ger. Tacitus, Germania (Trans. J. B. Rives), I999, Oxford: Oxford University Press

\section{SECONDARY SOURCES}

Aufderheide, A. C. And Rodriguez-Martin, C. 2003. The Cambridge Encyclopaedia of Human Paleopathology, Cambridge: Cambridge University Press

ANON. 20I3. Recent work on round barrows and cairns in Wales, Archaeol. Camb., I62, I9-32

Bass, W. I995. Human Osteology: A Laboratory and Field Manual, Archaeological Society Special Publication No. 2, Columbia, Missouri: Missouri Archaeology Society

Barclay, A. and Halpin, C. I999. Excavations at Barrow Hills, Radley, Oxfordshire. Volume I. The Neolithic and Bronze Age Monument Complex., Thames Valley Landscapes Monogr., II, Oxford: Oxford Archaeological Unit

Barford, P. M., Owen, W. G. and Britnell, W. J. ig86. Iron spearhead and javelin from Four Crosses, Llandysilio, Powys, Medieval Archaeol., 30, I03-6

Beck, C. and Shennan, S. I99 I Amber in Prehistoric Britain, Oxbow Monogr., 8, Oxford: Oxbow

Bennett, K. D. I994. Annotated Catalogue of Pollen and Pteridophyte Spore Types of the British Isles, unpublished report, Department of Plant Sciences University of Cambridge

BGS (British Geological Survey) http://maps.bgs.ac.uk viewed I4.I2.I I

Bourgeois, Q. 20I3. Monuments on the Horizon. The Formation of the Barrow Landscape throughout the 3rd and 2 nd Millennium BC. Leiden: Sidestone Press

Bowden, M., Soutar, S., Field, D. and Barber M. 2015. The Stonehenge Landscape: Analysing the Stonehenge World Heritage Site, Swindon: Historic England

Brickley, M. And McKinley, J. I. 2004. Guidelines to the Standards for Recording Human Remains, Southampton/Reading, BABAO/IFA Paper, No. 7

Britnell, W. I982. The excavation of two Round Barrows at Trelystan, Powys, Proc. Prehist. Soc., 48, I33$20 \mathrm{I}$

Britnell, W. J. And Jones, N.W. 20I2. Large late Neolithic and early Bronze Age ring ditches in Wales, Archaeol. Camb., I6I, I65-98

Bronk Ramsey, C. 2005. OxCal version 3.IO

Brothwell, D. R. i98 i. Digging up Bones, Oxford: Oxford University Press

Buikstra, J. E. And Ubelaker, D. H. I994. Standards for Data Collection from Human Skeletal Remains, Arkansas Archaeological Survey, No. 44, Fayetteville Arkansas Archaeologial Survey Research Series,

Bulleid, A. and Gray, H. G. I9I7. The Glastonbury Lake Village, Taunton: Glastonbury Antiquarian Society 
Cappers, T. R. J., Bekker, R. M. And Jans, J. E. A. 2006. Digitale Zadenatlas van Nederland: Digital Seed Atlas of the Netherlands, Groningen Archaeol. Stud., 4, Groningen: Barkhuis Publishing and Groningen University Library

Caseldine, A. I990. Environmental Archaeology in Wales, Lampeter: Saint David's University College

Caseldine, A. E. 2004. A Research Framework for the Archaeology of Wales: Nationals Seminar Paper, 4th September 2004 - Environmental Archaeology, Available from: http://www.cpat.org.uk/research/ns4env.htm, accessed July 2008

Caseldine A. E. 20I3. Pollen analysis at Craig y Dullfan and Banc Wernwgan and other recent palaeoenvironmental studies in Wales, Archaeol. Camb., I62, 275-307

Caseldine, A. E., And Griffiths, C. J. 20i3. Charred plant remains and charcoal, 53-9, in K. Murphy and F. Murphy, The excavation of two Bronze Age round barrows at Pany y Butler, Llangoedmor, Ceredigion, 2009-10, Archaeol. Camb., I62, 33-66

Chambers, F. M. I982a. Environmental history of Cefn Gwernffrwd, near Rhandirmwyn, Mid-Wales, New Phytologist, 92, 607-I5

Chambers, F. M. I982b. Two radiocarbon-dated pollen diagrams from high altitude blanket peats in South Wales, J. Ecol., 70, 445-59

Cleal, R. I999. Introduction: the what, where, when, and why of Grooved Ware, in R. Cleal and A. MacSween (eds) Grooved Ware in Britain and Ireland, Neolithic Studies Group Seminar Papers, 3, I-8, Oxford: Oxbow

Colls, K. and Halsted, J. 2009. New evidence for monument reuse in Bronze Age Wales: archaeological excavation at Llanymynech, Powys, 2007, Archaeol. Camb., I58, 69-96

Cotswold Archaeology, 2007. Land at Domgay Lane, Four Crosses, Powys, Post-Excavation Assessment, Cotswold Archaeology unpublished report 06046

Darvill, T. 20io. Prehistoric Britain, Second edition, London: Routledge

Darvill, T. 20I3. Monuments and monumentality in Bronze Age Europe, in H. Fokkens and A. Harding (eds) The Oxford Handbook of the European Bronze Age, I40-58, Oxford: Oxford University Press

Fleming, A. I97i. Territorial patterns in Bronze Age Wessex, Proc. Prehist. Soc., 37, I38-66

Fontijn, D., Louwen, A.J., van der Vaart, S. And Wentink, K. (eds) 20i3. Beyond Barrows. Current Research on the Structuration and Perception of the Prehistoric Landscape through Monuments, Leiden: Sidestone Press

Gale, R. and Cutler, D. 2000. Plants in Archaeology, Otley/London: Westbury/Royal Botanic Gardens, Kew

Gale, S. J. And Hoare, P. J. I99. Quaternary Sediments: Petrographic Methods for the Study of Unlithified Rocks, London: Belhaven Press

Garrow, D., Meadows, J., Evans, C. and Tabor, J. 20I4. Dating the dead: a high-resolution radiocarbon chronology of burial within an early Bronze Age barrow cemetery at Over, Cambridgeshire, Proc. Prehist. Soc., 80, 207-36

Garwood, P. I999. Grooved Ware in southern Britain: chronology and interpretation, in R. Clealand A. MacSween (eds) Grooved Ware in Britain and Ireland, Neolithic Studies Group Seminar Papers, 3, I $45-$ I76, Oxford: Oxbow

GarwoOd, P. 2007a. Before the hills in order stood: chronology, time and history in the interpretation of Early Bronze Age round barrows, in J. Last (ed.), Beyond the Grave: New Perspectives on Barrows, 30-52, Oxford: Oxbow

GarwoOd, P. 2007b. Late Neolithic and early Bronze Age funerary monuments and burial traditions in the West Midlands, in P. Garwood (ed.) The Undiscovered Country. The Earlier Prehistory of the West Midlands, The Making of the West Midlands, I, I34-65, Oxford: Oxbow,

Gibson, A. I992. The excavation of a ring-ditch at Elmtree Farm, Llanymynech, Powys, Archaeol. Wales, 32, I $5-$ I 7

Gibson, A. M. I994. Excavations at the Sarn-y-bryn-caled cursus complex, Welshpool, Powys, and the timber circles of Great Britain and Ireland, Proc. Prehist. Soc., 60, I43-223

Gibson, A. M. 1999. The Walton Basin Project: Excavation and Survey in a Prehistoric Landscape 1993-1997, Counc. Brit. Archaeol. Res. Rep., II8, York: Council for British Archaeology and Cadw Welsh Historic Monuments

Gibson, A. 2002. Earlier prehistoric funerary and ritual sites in the upper Severn Valley. Montgomeryshire Coll., 90, I-40

Gibson, A. 20io. Excavation and survey at Dyffryn Lane henge complex, Powys, and a reconsideration of the dating of henges, Proc. Prehist. Soc., 76, $2 \mathrm{I} 3-48$

Gibson, A. And Bayliss, A. 2009. Recent research at Duggleby Howe, North Yorkshire, Archaeol. J., I66, 3978 
Gibson, A. And Bayliss, A. 20io. Recent work on the Neolithic round barrows of the upper Great Wold Valley, Yorkshire, in J. Leary, T. Darvill and D. Field (eds) Round Mounds and Monumentality in the British Neolithic and Beyond, Neolithic Studies Group Seminar Papers, I0, 72-107, Oxford: Oxbow

Godwin, H. I956. The History of the British Flora, Cambridge: Cambridge University Press

Grant, I. 20I I. Four Crosses bypass, Archaeol. Wales, 50, 89 and ro9

Grinsell, L. V. I978. The Stonehenge Barrow Groups, Salisbury: Salisbury and South Wiltshire Museum

Halsted, J. 2007. Four Crosses, Domgay Lane, Archaeol. Wales, 47, I33-4

Harding, J. and Healy, F. 2007. The Raunds Area Project. A Neolithic and Bronze Age landscape in Northamptonshire, London: English Heritage

Jacklin, H. A. 2005. A New, Fully Standardised Skeletal Recording Form Following BABAO and IFA Guidelines, Unpublished

Jones, A. P., Tucker, M. E. and Hart, J. K. I999. Guidelines and recommendations, in A. P. Jones, M. E. Tucker and J. K. Hart (eds) The Description and Analysis of Quaternary Stratigraphic Field Sections, Quaternary Research Association Technical Guide, 7, Cambridge: Quaternary Research Association

Jones, N. W. 2002. Land off Domgay Road, Four Crosses, Powys: Archaeological Evaluation, Clwyd-Powys Archaeological Trust Report No. 487

Kaul, F. I998. Ships on Bronzes. A Study in Bronze Age Religion and Iconography, Pub. Nat. Museum Stud. Archaeol. Hist., 3, Copenhagen: Nationalmuseet

Kaul, F. 2004. Bronzealderens religion. Studier af den nordiske bronzealders ikonografi, Copenhagen: Det Kongelige Nordiske Oldskriftselskab

Kinnes, I. I979. Round barrows and ring ditches in the British Neolithic, Occasional Paper, 7, London: British Museum

Kinnes, I., Schadla-Hall, T., Chardwick, P. and Dean, P. i983. Duggleby Howe reconsidered, Archaeol. J., I40, 83-IO8

Kristiansen, K. and Larsson, T. B. 2005. The Rise of Bronze Age Society, Cambridge: Cambridge University Press

Last, J. I998. Books of life: biography and memory in a Bronze Age barrow, Oxford J. Archaeol., I7(I), 43-53

Last, J. (ed.) 2007. Beyond the Grave. New Perspectives on Barrows, Oxford: Oxbow

Leary, J., Darvill, T. And Field, D. (eds) 20io. Round Mounds and Monumentality in the British Neolithic and Beyond, Neolithic Stud. Group Seminar Papers, Io, Oxford: Oxbow

Le Borgne, E. I960. Influence du feu sur les propriétés magnétiques du sol et sur celles du schiste et du granite, Annals of Geophysics, I6, I 59-I95

Longworth, I. H. I97I. The Neolithic pottery, in Wainwright and Longworth I97I, 75-I24

Lynch, F. M. I993. Excavations in the Brenig Valley. A Mesolithic and Bronze Age Landscape in North Wales, Cambrian Archaeol. Assoc. Monogr., 5, Cardiff: Cambrian Archaeological Association

MacGregor, A. And Bolick, E. I993. A Summary Catalogue of the Anglo-Saxon Collections (Non-Ferrous Metals) in the Ashmolean Museum, Oxford: Brit. Archaeol. Rep. Brit. Ser., 230

Maher, B. A. I986. Characterization of soils by mineral magnetic measurements, Physics of Earth and Planetary Interiors, 42, 76-92

Marches Archaeology. 2003. Land off Domgay Lane, Four Crosses, Powys: Report on an Archaeological Evaluation, Marches Archaeology Series 297

Martin, A. L. I996. Barton-under-Needwood, Tucklesholme Farm (SK 208 I88), West Midlands Archaeology, 39, Council for British Archaeology West Midlands, 66

Martin, A. 20I I. The alien within: the forgotten sub-cultures of early Bronze Age Wessex, in A.M Jones and G. Kirkham (eds), Beyond the Core. Reflections on Regionality in Prehistory, 63-73, Oxford: Oxbow Books

MCSloy, E. 2006.The metalwork and worked bone, 34, in D. Evans, N. Holbrook, and E. McSloy, A Later Iron Age Cemetery and Roman Settlement at Henbury School, Bristol: Excavations in 2004, I-5O, in M. Watts (ed.) Two Cemeteries from Bristol's Northern Suburbs, Bristol and Gloucestershire Archaeological Report, 4

MCSLOY, E. 2008. Metal and glass objects, 55-57, in A. Barber and M. Watts, Excavations at Saxon's Lode Farm, Ryall Quarry, Ripple, 200I-2: Iron Age, Romano-British and Anglo-Saxon rural settlement in the Severn Valley, Trans. Worcestershire Archaeol. Soc., 3 ser. 2I, I-90

MCKinley, J. L. I994. Bone fragment size in British cremation burials and its implications for pyre technology and ritual, J. Archaeol. Sci., 2I.3, 339-42

McKinley, J. L. 2000a. Putting cremated bone into context, in S. Roskams (ed.) Interpreting Stratigraphy; Site Evaluation, Recording Procedures and Stratigraphic Analysis, I35-40, Oxford: Brit. Archaeol. Rep., Int. Ser., 9I0

McKinley, J. L. 20oob. The analysis of cremated bone, in M. Cox and S. Mays (eds) Human Osteology, 403-2 I, Greenwich Medical Media: London 
McKinley, J. L. and Bond, J. M. 200I. Cremated bone, in D. R. Brothwell and A. M. Pollard (eds) Handbook of Archaeological Sciences, 28 I-92, Wiley: Chichester

McKinley, J. L. And Roberts, C. A. I993. Excavation and Post-Excavation Treatment of Cremated and Inhumed Human Remains, IFA Technical Paper. No. $\mathbf{I 3}$

Milles, A. I986. Charred plant remains from a Beaker pit at Site 2, Four Crosses, in W. Warrilow, G. Owen, and W. J. Britnell, Eight ring ditches at Four Crosses, Llandysilo, Powys, I98 I-85, Proc. Prehist. Soc., 52, Microfiche Io

Millson, D., Waddington, C. and Marshall, P. 20I i. Towards a Sequence for Neolithic Ceramics in the Milfield Basin, and Northumberland, Archaeologia Aeliana, 5th ser., 40, I-40

Mrtchell, A. I974. A Field Guide to the Trees of Britain and Northern Europe. London: Collins

Mizoguchi, K. I992. A historiography of a linear barrow cemetery: a structuralist's point of view, Archaeol. Rev. Cambridge, II(I), 39-49

Monckton, A. 2009. Charred plant remains, i 56-9, in S. C, Palmer, Neolithic, Bronze Age, Iron Age, Romano-British and Anglo-Saxon sites excavated on the Transco Churchover to Newbold Pacey gas pipeline in I999, Trans. Birmingham Warwickshire Archaeol. Soc., II3, I-I74

Moore, P. D., Webb, J. A. And Collinson, M. E. i99i. Pollen Analysis, Oxford: Blackwell Scientific Publications

Mullin, D 2003. The Bronze Age Landscape of the Northern English Midlands, Oxford: Brit. Archaeol. Rep., Brit. Ser., 35I

Murphy, K. I992. Plas Gogerddan, Dyfed: a multi-period burial and ritual site, Archaeol. J., 44, I-38

Munsell Color 2000. Munsell Soil Color Charts, New Windsor (NY): Munsel Color

Musson, C. R., Britnell, W. J., Northover, J. P. and Salter, C. J. i992. Excavations and metal-working at Llwyn Bryn-Dinas Hillfort, Llangedwyn, Clwyd, Proc. Prehist. Soc., 58, 265-83

Musson, C. R. And Northover, J. P. I989. Llanymynech hillfort, Powys and Shropshire: observations on construction work, I98I. Montgomeryshire Coll., 77, I 5-26

Needham, S. 2005. Transforming Beaker culture in north-west Europe: processes of fusion and fission, Proc. Prehist. Soc., 7I, I7I-2I7.

Northover, J. P. I99I. Microfiche Appendix I3.4: Further comments on the composition of the Breiddin bronzes, in C. R. Musson, The Breiddin Hillfort: a later Prehistoric Settlement in the Welsh Marches, London, Council for British Archaeology

Ortner, D. J. 2003. Identification of Pathological Conditions in Human Skeletal Remains, Washington D.C.: Smithsonian Institution, Natural Museum of Natural History Academic Press

Owen, G. And Britnell, W. I989. Alignments at Four Crosses, Llandysilio, Powys, Montgomeryshire Coll., 77, 27-40

PeAcock, D. P. S. I967. Romano-British pottery production in the Malvern district of Worcestershire, Trans. Worcestershire Archaeol. Soc., 3 ser. I, I 5-28

Pearson, E. 200I. Palaeoenvironmental data, I2, in A. Martin and C. Allen, Two prehistoric ring ditches and an associated Bronze Age cremation cemetery at Tucklesholme Farm, Barton-under-Needwood, Staffordshire, Trans. Staffordshire Archaeol. Hist. Soc., 39, I-I5

Pearson, E. 2006. Assessment of Environmental Remains from Domgay Lane, Four Crosses, Powys, Worcestershire County Council, Historic Environment and Archaeology Service unpublished report, I462

Pearson, E. 20I2. Charred plant remains, 50-6, in P. Thompson and S. C. Palmer, Iron Age, Romano-British and medieval settlements excavated on the Transco Newbold Pacey to Honeybourne gas pipeline in 2000, Trans. Birmingham Warwickshire Archaeol. Soc., II6, I-I39

Petts, D. 2002. Cemeteries and boundaries in Western Britain, in S. Lucy and A. Reynolds (eds) Burial in Early Medieval England and Wales, Soc. Medieval Archaeol. Monogr. Ser., I7, 24-46, Leeds: Maney

Pollock, K. J. 2006. The Evolution and Role of burial Practice in Roman Wales, Oxford: Brit. Archaeol. Rep. Brit. Ser., 426

Ray, K. And Bapty, I. 20i6. Offa's Dyke: Landscape and Hegemony in Eighth-Century Britain, Oxford: Windgather

Reimer P. J., Baillie, M. G. L., Bard, E., Bayliss, A., Beck, J. W., Bertrand, C., Blackwell, P. G., Buck, C. E., Burr, G., Cutler, K. B., Damon, P. E., Edwards, R. L., Fairbanks, R. G., Friedrich, M., Guilderson, T. P., Hughen, K. A., Kromer, B., McCormac, F. G., Manning, S., Bronk Ramsey, C., Reimer, R. W., Remmele, S. M., Southon, J. R., Stuiver, M., Talamo, S., Taylor, F. W., VAN der Plicht, J. AND Weyhenmeyer, C. E. 2004. INTCALo4 Terrestrial radiocarbon age calibration, 0-26 CAL KYR BP, Radiocarbon, 46, I029-58

Rogers, J. And Waldron, T. I995. A Field Guide to Joint Disease in Archaeology, Oxford: John Wiley and Sons 
Scheuer, L. And Black, S. 2000. Developmental Juvenile Osteology, London: Academic Press

Semple, S. 2013. Perceptions of the Prehistoric in Anglo-Saxon England, Oxford: Oxford University Press

Sмith, W. 2002. A Review of Archaeological Wood Analyses in Southern England, English Heritage Centre for Archaeol. Lab. Rep. No. 75, London: English Heritage

Stace, C. 200I. New Flora of the British Isles, 2nd Edition, Cambridge: Cambridge University Press

Stanford, S. I982. Bromfield, Shropshire - Neolithic, Beaker and Bonze Age sites, I966-79, Proc. Prehist. Soc., 48, 279-320

Stuiver, M. and Polach, H. A. I977. Reporting of ${ }^{\mathrm{I} 4} \mathrm{C}$ data, Radiocarbon, I9, 355-63

Stuiver, M. and Reimer, P. J. I993. Extended ${ }^{14} \mathrm{C}$ database and revised CALIB 3.0 I4C Age calibration program, Radiocarbon 35(I), 2 I 5-30

Taylor, A. F. And Woodward, P. J. I985. A Bronze Age barrow cemetery, and associated settlement at Roxton, Bedfordshire, Archaeol. J., I42, 73-I 49

Thomas, C. I98I. Christianity in Roman Britain to 500 AD, Berkeley, CA: University of California Press

Tomber, R. And Dore, J. I998. The National Roman Fabric Reference Collection: A Handbook, London: Museum of London Archaeology Service

Tuck, M., Turner, R. G. And Penney S. 2003. Abernant, Kemmeys inferior, Archaeol. Wales, 43, I20-3

Tucker, M. E. I982. Sedimentary Rocks in the Field, Chichester: Wiley

Tutin, T. G., Heywood, V. H. Tutin, T. G, Heywood, V. H., Burgess, N.A., Moore, D. M., Valentine, D. H., Walters, S. M. and Webb, D. A. I964-80. Flora Europaea, I-5, Cambridge: Cambridge University Press

VAN DER Veen, M. I985. Plant remains, I46-7 in R. Miket, Ritual enclosures at Whitton Hill, Northumberland. Proc. Prehist. Soc., 5I, I 37-48

Wainwright, G. J. and Longworth, I. H. I97i. Durrington Walls: Excavations 1966-1968 London, Research Committee of the Society of Antiquaries of London Report 37

Warrilow, W., Owen G. And Britnell, W. I986. Eight Ring ditches at Four Crosses. Llandysilio, Powys, I98 I-85, Proc. Prehist. Soc., 52, 53-88

Webster, P. V. I976. Severn Valley ware: a preliminary study, Trans. Bristol Gloucestershire Archaeol. Soc., 94 , I $8-46$

White, R. B. I972. Excavations at Arfyn: Bodedern, long-cist cemeteries and the origins of Christianity in Britain, Angelsey Antiq. Soc. and Field Club, I9-45

Wigley, A. 2007. Pitted histories: early first millennium BC pit alignments in the central Welsh Marches, in C. Haselgrove and R. Pope (eds), The Earlier Iron Age in Britain and the Near Continent, Oxford: Oxbow Books, II9-34

Wilson, D. R. I978. Pit alignments: distribution and function, in H. C. Bowen and P. J. Fowler (eds), Early Land Allotment, Oxford: British Archaeol. Rep. Brit. Ser., I2, 3-6

Woodward, A. 2000. British Barrows. A Matter of Life and Death, Stroud: Tempus

\title{
APPENDIX: BARROWS AND RING DITCHES IN THE FOUR CROSSES BARROW CEMETERY
}

\author{
by Timothy DarVill
}

For numbering, see Illus 2 and 20.

(I) Barrow excavated I98 I-83 (Warrilow et al. I986, 55-7). Central pit, ?inhumation but no surviving bone, the fill cut by a timber marker-post. Charcoal from the postpipe gave a date of I900-I 530 cal. BC (CAR-666: 3420 $\pm 65 \mathrm{BP})$. Central four-stake structure centred on the post-hole. Six concentric stake circles centred on the post-hole/grave pit. Covering mound with residual material in the matrix. Concentric ring ditch about $24 \mathrm{~m}$ in diameter; I.6-I. $8 \mathrm{~m}$ across and $0.75 \mathrm{~m}$ deep below the natural gravel surface. Pieces of three urns from eroded mound material.

(2) Ring ditch excavated I984 (Warrilow et al. I986, 57-6I) and within the area excavated in 2004-6. Pre-barrow activity represented by residual charcoal from fill of Grave 4 dated to $6360-5920 \mathrm{cal}$. BC (CAR-849: 7250 $\pm 90 \mathrm{BP})$, a chisel arrowhead and a pit containing pieces of seven Beaker pots, burnt clay, barley grains and charcoal. Radiocarbon dates of 2910-2570 cal. BC (CAR-767: 4190 $\pm 70 \mathrm{BP}), 2570-2 \mathrm{I} 40 \mathrm{cal}$. BC (CAR-8I I: 3890 $\pm 70 \mathrm{BP})$, and 2290-I890 cal. BC (CAR-8 IO: 3690 
$\left.\pm_{70} \mathrm{BP}\right)$ from charcoal in the pit. Central grave, ?inhumation but no surviving bone. No mound surviving. Ring ditch $\mathrm{I} 3 \mathrm{~m}$ in diameter, $2.3-3.2 \mathrm{~m}$ wide and $\mathrm{I} \mathrm{m}$ deep from the gravel surface. Evidence of metalworking on or around the mound associated with a radiocarbon date of $370-20$ cal. BC (CAR-766: 2 I $30 \pm 60 \mathrm{BP})$. Five graves, one (Grave 2) with surviving skeletal remains and carbonized material that gave a radiocarbon date of 350 BC-90 cal. AD (CAR-765: 2050 $\pm 70 \mathrm{BP}$ ). Sixth- or seventh-century AD javelin and spear deposited in upper ditch fill on the north side of the ring ditch.

(3) Ring ditch excavated in 1984 (Warrilow et al. I986, 62) and within the area excavated in 2004-6. No surviving mound. No central features. Ring ditch $7.7 \mathrm{~m}$ diameter, $2 \mathrm{~m}$ wide and $0.6 \mathrm{~m}$ deep from the surface of the natural gravel. Truncated by i 8 th century field-boundary.

(4) Ring ditch excavated in 1982 (Warrilow et al. I986, 62-3). No surviving mound. No central features. Ring ditch $17.5 \mathrm{~m}$ diameter, $3 \mathrm{~m}$ wide and I $\mathrm{m}$ deep from the surface of the natural gravel.

(5) Multi-phase barrow excavated in I983 (Warrilow et al. I986, 63-8). Slight traces of a mound. Phase I. Central shaft $4.5 \mathrm{~m}$ by $3.8 \mathrm{~m}$ by I. $4 \mathrm{~m}$ deep. Steep sided with a central burial: ?crouched inhumation but very little surviving bone. Grave-goods comprised a plain Neolithic bowl and a small pear-shaped stone. Either side of the burial was a slot $\mathrm{I} .3 \mathrm{~m}$ by $0.5 \mathrm{~m}$ by $0.4 \mathrm{~m}$ deep; these could have contained further burials. Charcoal from above the northern slot radiocarbon dated to 3340-29IO cal. BC (CAR-670: $4440 \pm 70 \mathrm{BP})$. Surrounding ring ditch $20.5 \mathrm{~m}-2 \mathrm{I} .7 \mathrm{~m}$ diameter, $2.6 \mathrm{~m}$ wide, I.I I $\mathrm{m}$ deep below the surface of the natural gravel. Fragments of a Mortlake bowl and Beaker in the upper ditch fill. Phase 2. Central shallow grave $1.25 \mathrm{~m}$ by $2.5 \mathrm{~m}$ by $0.6 \mathrm{~m}$ deep. Slight traces of bone suggesting an extended inhumation, possibly in coffin, accompanied by a jet/shale button. Ring ditch I $6 \mathrm{~m}$ diameter, I. $2 \mathrm{~m}$ wide and $0.8 \mathrm{~m}$ deep below the surface of the natural gravel. Charcoal in the secondary ditch silt was radiocarbon dated to $3090-2620 \mathrm{cal}$. BC (CAR-671: $4260 \pm 70 \mathrm{BP}$ ). Phase 3 . No central grave recorded. Stake-circle $14.5 \mathrm{~m}$ in diameter cut into the Phase 2 ditch. Traces of mound with residual cultural material including Beaker pottery and a flint knife. Ring ditch $26.4 \mathrm{~m}$ in diameter, $2 \mathrm{~m}$ wide and I.2 $\mathrm{m}$ deep below the surface of the natural gravel. Charcoal in a stabilization horizon with the ditch fill was radiocarbon dated to I880-I $520 \mathrm{cal} \mathrm{BC}(\mathrm{CAR}-668: 3390 \pm 70 \mathrm{BP})$. Charcoal from a pit cutting the stabilization horizon was dated to 2030-I660 cal BC (CAR-669: 35IO $\pm 70 \mathrm{BP})$. Some evidence for later cremations deposited in the mound. Fragments of a bronze dagger found outside the Phase 3 ditch.

(6) Barrow excavated in 1983 (Warrilow et al. 1986, 68). Pre-mound activity represented by a Mesolithic flint scraper. Central oval hollow, perhaps a grave but no bone surviving. Slight traces of a mound. Ring ditch $5 \mathrm{~m}$ diameter, $0.5-0.6 \mathrm{~m}$ wide and $0.3 \mathrm{~m}$ deep from the surface of the natural gravel.

(7) Barrow excavated in $1984-5$ (Warrilow et al. I986, 69-70). Pre-mound activity represented by a central post-hole I.I-I.2 m across and I.48 m deep. No evidence for a grave. Slight traces of a mound with residual cultural material including Beaker and Food Vessel. Ring ditch $35 \mathrm{~m}$ diameter, $3 \mathrm{~m}$ wide and $\mathrm{I} .45 \mathrm{~m}$ deep from the surface of the natural gravel. Ditch cut by a pit containing charcoal dated to I700-I $420 \mathrm{cal}$. BC (CAR-648: $3280 \pm 70 \mathrm{BP})$.

(8) Barrow excavated in 1984 as a 'satellite' to Barrow 2 (Warrilow et al. I986, 6I-2) and within the area excavated in 2004-6. Central grave: ?inhumation but no surviving bone. Pine charcoal from the upper fill of the grave dated to $5980-5720$ cal BC (CAR-850: 6990 \pm 80 BP). No surviving mound. Ring ditch $6.8 \mathrm{~m}$ diameter, $0.5 \mathrm{~m}$ wide and $0.3 \mathrm{~m}$ deep below the natural gravel surface.

(9) ?Barrow excavated in 2004-6. CA archive ref. Ring ditch I. No central feature. Ring ditch $30 \mathrm{~m}$ diameter, $\mathrm{I} .35 \mathrm{~m}$ wide and $0.8 \mathrm{~m}$ deep below the natural gravel surface.

(Iо) ?Barrow excavated in 2004-6. CA archive ref. Ring ditch 2. Ring ditch $8.2 \mathrm{~m}$ diameter, $0.25-0.45$ $\mathrm{m}$ wide and $0.5 \mathrm{~m}$ deep below the natural gravel surface below the natural gravel surface.

(I I) ?Barrow excavated in 2004-6. CA archive ref. Ring ditch 3. Ring ditch 7.5 $\mathrm{m}$ diameter, $0.8-\mathrm{I} \mathrm{m}$ wide and $0.2 \mathrm{~m}$ deep below the natural gravel surface.

(I2) ?Barrow excavated in 2004-6. CA archive ref. Ring ditch 4. Ring ditch $8.7 \mathrm{~m}$ diameter, $0.7-\mathrm{I} \mathrm{m}$ wide and $0.37-0.5 \mathrm{~m}$ deep below the natural gravel surface. Central grave with charred hazelnut shells and wheat, ?inhumation but no bone surviving.

(г 3) ?Barrow excavated in 2004-6. CA archive ref. Ring ditch 5. Ring ditch $7.9 \mathrm{~m}$ diameter, 0.5 - $\mathrm{Im}$ wide and $0.2-0.3 \mathrm{~m}$ deep. Oval pit $2.8 \mathrm{~m}$ by I. $8 \mathrm{~m}$ was cut through the fill of the ring ditch below the natural gravel surface. 
(I4) ?Barrow excavated in 2004-6. CA archive ref. Ring ditch 6. Central grave containing fragments of adult inhumation dated to $2 \mathrm{IO}-40 \mathrm{O}$ cal BC (Wk-23236: 2 IO $04 \pm 32 \mathrm{BP}$ ). Ring ditch IO $\mathrm{m}$ diameter, I. $5 \mathrm{~m}$ wide and $0.45-0.75 \mathrm{~m}$ deep below the natural gravel surface.

(i s) ?Barrow excavated in 2004-6. CA archive ref. Ring ditch 7. Central grave dated to the Iron Age by the presence of a finger-ring, but no bone survived. Ring ditch $5.5 \mathrm{~m}$ diameter, $0.6 \mathrm{~m}$ wide and 0.3 $\mathrm{m}$ deep below the natural gravel surface but does not survive as a complete circuit.

(I6) ?Barrow excavated in 2004-6. CA archive ref. Ring ditch 8. Possible central grave. Ring ditch 7.5 $\mathrm{m}$ diameter, $0.45^{-\mathrm{I}} \mathrm{m}$ wide and $0.4 \mathrm{~m}$ deep below the natural gravel surface.

(17) ?Barrow excavated in 2004-6. CA archive ref. Ring ditch 9. Possible central grave. Ring ditch 5.8 $\mathrm{m}$ diameter, $0.3-0.5 \mathrm{~m}$ wide and $0.3 \mathrm{~m}$ deep below the natural gravel surface.

(18) ?Barrow excavated in 2004-6. CA archive ref. Ring ditch Io. Ring ditch $5.5 \mathrm{~m}$ diameter, $0.25 \mathrm{~m}$ wide and $0.3 \mathrm{~m}$ deep below the natural gravel surface. Central grave, adult inhumation but little bone surviving.

(19) ?Barrow excavated in 2004-6. CA archive ref. Ring ditch I I. Possible central grave. Ring ditch 5.5 $\mathrm{m}$ diameter, $0.4 \mathrm{~m}$ wide and $0.3 \mathrm{~m}$ deep below the natural gravel surface but not surviving as a complete circuit.

(20) Multi-phase barrow part-excavated in 2004-6. CA archive ref. Ring ditches I4 and I $5 /$ barrow mound. Phase I: No internal features within the area investigated. Traces of low mound over immature (? previously truncated) soil profile. Ring ditch $\mathrm{I} 6 \mathrm{~m}$ in diameter but not continuous, $\mathrm{I} .9 \mathrm{~m}-2.5 \mathrm{~m}$ wide and I.2 $\mathrm{m}$ deep below the surface of the natural gravel. Pit cut into the mound soon after construction. Phase 2: No internal features within the area investigated. Mound $\mathrm{I} 8 \mathrm{~m}$ in diameter. Ring ditch $20 \mathrm{~m}$ in diameter, I.I $\mathrm{m}$ wide and $0.6 \mathrm{~m}$ deep below the surface of the natural gravel.

(2I) Cropmark ring ditch /barrow. No investigation.

(22) Cropmark ring ditch /barrow. No investigation.

(23) Cropmark ring ditch /barrow. No investigation.

(24) Cropmark ring ditch /barrow. No investigation.

(25) Cropmark ring ditch /barrow. No investigation.

(26) Cropmark ring ditch /barrow. No investigation.

(27) Ring ditch excavated 20Io (Grant 20I I) No surviving mound. Central pit with a small quantity of cremated bone in the north-western end of the pit, possibly in association with two small flints. A sample of the bone dated to $2030-1770 \mathrm{cal}$. BC (SUERC $342 \mathrm{I}$ ). Ring ditch $23 \mathrm{~m}$ diameter $0.7 \mathrm{~m}$ wide and up to $0.6 \mathrm{~m}$ deep. Two small sherds of prehistoric pottery from the basal fill of the ditch, and charcoal which was dated to 2I40-I900 cal. BC (SUERC 342I6).

Tim Havard, Senior Project Officer, Cotswold Archaeology, Building I I, Kemble Enterprise Park, Cirencester, Gloucestershire GL7 6BQ

Email: tim.havard@cotswoldarchaeology.co.uk

Timothy Darvill, Professor of Archaeology and Director of the Centre for Archaeology and Anthropology, Bournemouth University, Christchurch House Ci 37, Talbot Campus, Fern Barrow, Poole, $\mathrm{BH}{ }_{2}{ }_{5} \mathrm{BB}$

Email: tdarvill@bournemouth.ac.uk

Mary Alexander, Post-Excavation Manager, Cotswold Archaeology, Building II, Kemble Enterprise Park, Cirencester, Gloucestershire GL7 6BQ

Email: mary.alexander@cotswoldarchaeology.co.uk 